Ed. 40_Vol. 10_N. ${ }^{\circ} 4$ Diciembre 2021 - Marzo 2022

Publicación trimestral ISSN: $2254-4143$

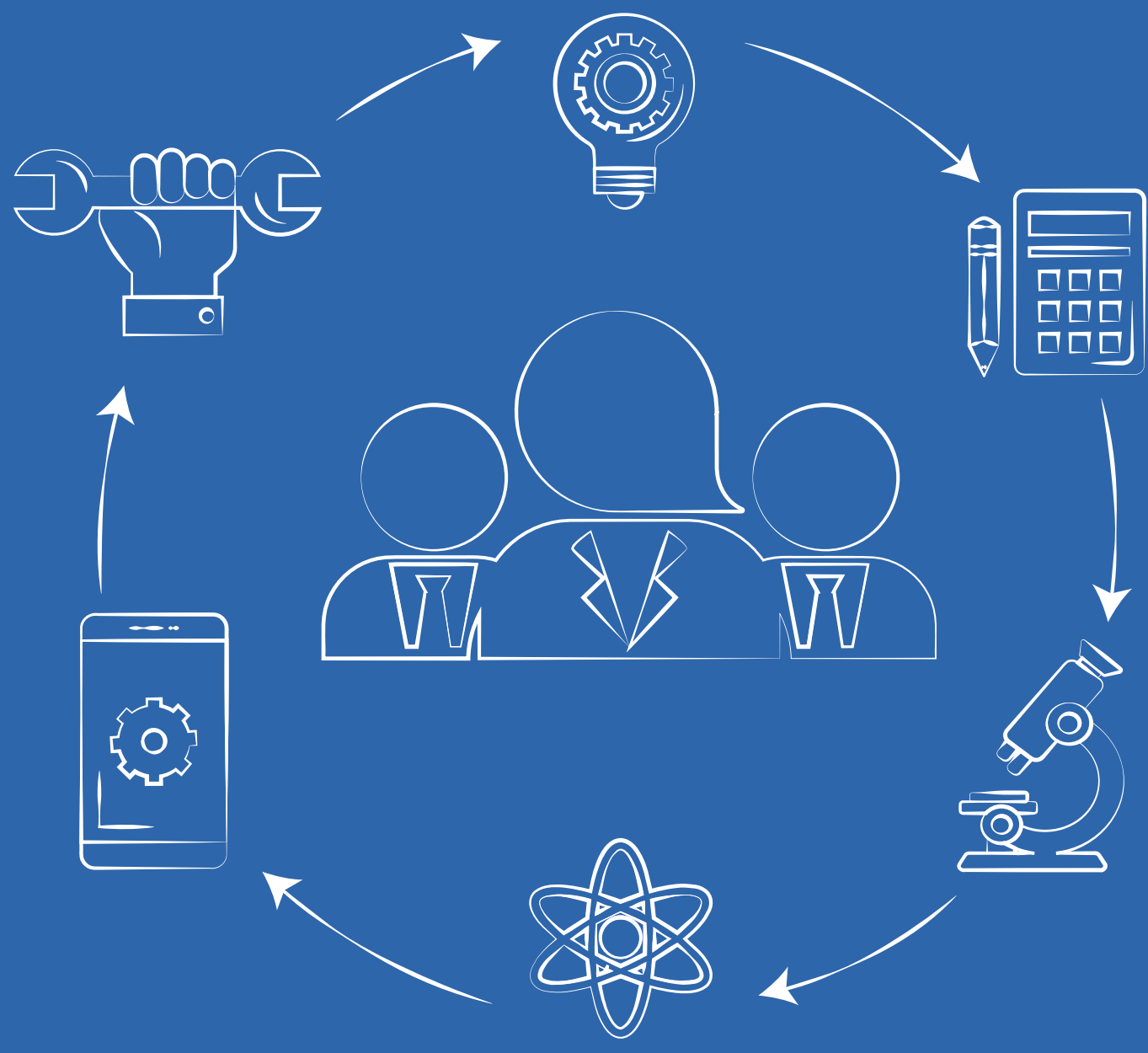




\section{C Tecnología. Glosas de innovación aplicadas a la pyme.}

Periodicidad trimestral. Quarterly periodicity.

Edición 40, Volumen 10, Número 4 (Diciembre 2021 - Marzo 2022).

Edition 40, Volume 10, Issue 4 (December 2021 - March 2022).

Tirada nacional e internacional. National and internacional circulation.

Artículos revisados por el método de evaluación de pares de doble ciego.

Articles revierwed by the double blind peer evaluation method.

ISSN: $2254-4143$

$\mathrm{N}^{\circ}$ de Depósito Legal: A $268-2012$

DOI: https://doi.org/10.17993/3ctecno/2021.v10n4e40

Edita:

Área de Innovación y Desarrollo, S.L.

Avda. Juan Gil Albert, 1, Alcoy, Alicante (España)

Tel: 965030572

info@3ciencias.com _www.3ciencias.com

\section{(C) $(1) \Theta$}

Todos los derechos reservados. Se autoriza la reproducción total o parcial de los artículos citando la fuente y el autor.

This publication may be reproduced by mentioning the source and the authors.

Copyright (C) Área de Innovación y Desarrollo, S.L. 


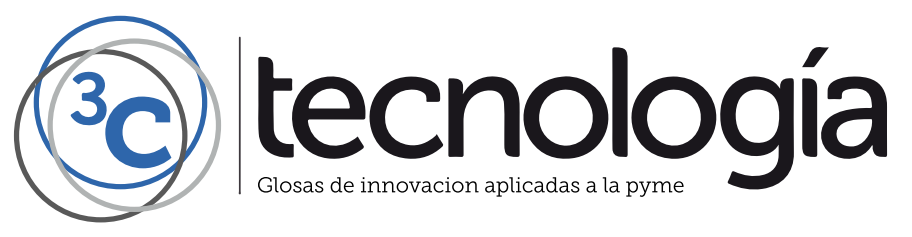




\section{CONSEJO EDITORIAL EDITORIAL BOARD}

Director

Editores adjuntos

Editores asociados
Víctor Gisbert Soler

María J. Vilaplana Aparicio

Maria Vela Garcia

David Juárez Varón

F. Javier Cárcel Carrasco

\section{CONSEJO DE REDACCIÓN DRAFTING BOARD}

Dr. David Juárez Varón. Universitat Politècnica de València (España)

Dra. Úrsula Faura Martínez. Universidad de Murcia (España)

Dr. Martín León Santiesteban. Universidad Autónoma de Occidente (México)

Dra. Inmaculada Bel Oms. Universitat de València (España)

Dr. F. Javier Cárcel Carrasco. Universitat Politècnica de València (España)

Dra. Ivonne Burguet Lago. Universidad de las Ciencias Informáticas (La Habana, Cuba)

Dr. Alberto Rodríguez Rodríguez. Universidad Estatal del Sur de Manabi (Ecuador)

\section{CONSEJO ASESOR ADVISORY BOARD}

Dra. Ana Isabel Pérez Molina. Universitat Politècnica de València (España)

Dr. Julio G. Pino Tarragó. Universidad Estatal del Sur de Manabi (Ecuador)

Dra. Irene Belmonte Martín. Universidad Miguel Hernández (España)

Dr. Jorge Francisco Bernal Peralta. Universidad de Tarapacá (Chile)

Dra. Mariana Alfaro Cendejas. Instituto Tecnológico de Monterrey (México)

Dr. Roberth O. Zambrano Santos. Instituto Tecnológico Superior de Portoviejo (Ecuador)

Dra. Nilda Delgado Yanes. Universidad de las Ciencias Informáticas (La Habana, Cuba)

Dr. Sebastián Sánchez Castillo. Universitat de València (España)

Dra. Sonia P. Ubillús Saltos. Instituto Tecnológico Superior de Portoviejo (Ecuador)

Dr. Jorge Alejandro Silva Rodríguez de San Miguel. Instituto Politécnico Nacional (México) 


\section{CONSEJO EDITORIAL EDITORIAL BOARD}

Área financiera

Área téxtil

Ciencias de la Salud

Derecho

Economía y empresariales

Estadística y Investigación operativa

Ingeniería y Tecnología

Organización de empresas y RRHH

Sinología

Sociología y Ciencias Políticas

Tecnologías de la Información y la Comunicación
Dr. Juan Ángel Lafuente Luengo

Universidad faime I (España)

Dr. Josep Valldeperas Morell

Universitat Politècnica de Cataluña (España)

Dra. Mar Arlandis Domingo

Hospital San Juan de Alicante (España)

Dra. María del Carmen Pastor Sempere

Universidad de Alicante (España)

Dr. José Joaquín García Gómez

Universidad de Almería (España)

Dra. Elena Pérez Bernabeu

Universitat Politècnica de València (España)

Dr. David Juárez Varón

Universitat Politècnica de València (España)

Dr. Francisco Llopis Vañó

Universidad de Alicante (España)

Dr. Gabriel Terol Rojo

Universitat de València (España)

Dr. Rodrigo Martínez Béjar

Universidad de Murcia (España)

Dr. Manuel Llorca Alcón

Universitat Politècnica de València (España) 


\section{POLÍTICA EDITORIAL}

\section{OBJETIVO EDITORIAL}

La Editorial científica 3Ciencias pretende transmitir a la sociedad ideas y proyectos innovadores, plasmados, o bien en artículos originales sometidos a revisión por expertos, o bien en los libros publicados con la más alta calidad científica y técnica.

\section{COBERTURA TEMÁTICA}

3C Tecnología es una revista de carácter científico-social en la que se difunden trabajos originales que abarcan la Arquitectura y los diferentes campos de la Ingeniería, como puede ser Ingeniería Mecánica, Industrial, Informática, Eléctrica, Agronómica, Naval, Física, Química, Civil, Electrónica, Forestal, Aeronáutica y de las Telecomunicaciones.

\section{NUESTRO PÚBLICO}

- Personal investigador.

- Doctorandos.

- Profesores de universidad.

- Oficinas de transferencia de resultados de investigación (OTRI).

- Empresas que desarrollan labor investigadora y quieran publicar alguno de sus estudios. 


\section{AIMS AND SCOPE}

\section{PUBLISHING GOAL}

3Ciencias wants to transmit to society innovative projects and ideas. This goal is reached thought the publication of original articles which are subdue to peer review or thorough the publication of scientific books.

\section{TEMATIC COVERAGE}

3C Tecnología is a scientific-social journal in which original works that cover Architecture and the different fields of Engineering are disseminated, such as Mechanical, Industrial, Computer, Electrical, Agronomic, Naval, Physics, Chemistry, Civil, Electronics, Forestry, Aeronautics and Telecommunications.

\section{OUR TARGET}

- Research staff.

- PhD students.

- Professors.

- Research Results Transfer Office.

- Companies that develop research and want to publish some of their works. 


\section{NORMAS DE PUBLICACIÓN}

3C Tecnología es una revista arbitrada que utiliza el sistema de revisión por pares de doble ciego (doubleblind peer review), donde expertos externos en la materia sobre la que trata un trabajo lo evalúan, siempre manteniendo el anonimato, tanto de los autores como de los revisores. La revista sigue las normas de publicación de la APA (American Psychological Association) para su indización en las principales bases de datos internacionales.

Cada número de la revista se edita en versión electrónica (e-ISSN: 2254 - 4143), identificándose cada trabajo con su respectivo código DOI (Digital Object Identifier System).

\section{PRESENTACIÓN TRABAJOS}

Los artículos se presentarán en tipo de letra Baskerville, cuerpo 11, justificados y sin tabuladores. Han de tener formato Word. La extensión será de no más de 6.000 palabras de texto, incluidas referencias. Los trabajos deben ser enviados exclusivamente por plataforma de gestión de manuscritos OJS:

https://ojs.3ciencias.com/

Toda la información, así como las plantillas a las que deben ceñirse los trabajos se encuentran en:

https://www.3ciencias.com/revista/informacion-para-autores/

https://www.3ciencias.com/normas-de-publicacion/plantillas/ 


\section{SUBMISSION GUIDELINES}

3C Tecnología is an arbitrated journal that uses the double-blind peer review system, where external experts in the field on which a paper deals evaluate it, always maintaining the anonymity of both the authors and of the reviewers. The journal follows the standards of publication of the APA (American Psychological Association) for indexing in the main international databases.

Each issue of the journal is published in electronic version (e-ISSN: $2254-4143$ ), each work being identified with its respective DOI (Digital Object Identifier System) code.

\section{PRESENTATION WORK}

The papers will be presented in Baskerville typeface, body 11 , justified and without tabs. They must have Word format. The extension will be no more than 6.000 words of text, including references. Papers must be submitted exclusively by OJS manuscript management platform:

https://ojs.3ciencias.com/

All the information, as well as the templates to which the works must adhere, can be found at: https://www.3ciencias.com/en/journals/infromation-for-authors/ https://www.3ciencias.com/en/regulations/templates/ 


\section{ESTRUCTURA}

Los trabajos originales tenderán a respetar la siguiente estructura: introducción, métodos, resultados, discusión/conclusiones, notas, agradecimientos y referencias bibliográficas.

Es obligatoria la inclusión de referencias, mientras que notas y agradecimientos son opcionales. Se valorará la correcta citación conforme a la 7. edición de las normas APA.

\section{RESPONSABILIDADES ÉTICAS}

No se acepta material previamente publicado (deben ser trabajos inéditos). En la lista de autores firmantes deben figurar única y exclusivamente aquellas personas que hayan contribuido intelectualmente (autoría), con un máximo de 4 autores por trabajo. No se aceptan artículos que no cumplan estrictamente las normas.

\section{INFORMACIÓN ESTADÍSTICA SOBRE TASAS DE ACEPTACIÓN E INTERNACIONALIZACIÓN}

- $\quad$ Número de trabajos aceptados publicados: 5.

- Nivel de aceptación de manuscritos en este número: 71,4\%.

- $\quad$ Nivel de rechazo de manuscritos: $28,6 \%$.

- Internacionalización de autores: 3 países (Perú, Pakistán y Sudáfrica).

Normas de publicación: https://www.3ciencias.com/normas-de-publicacion/instrucciones/ 


\section{STRUCTURE}

The original works will tend to respect the following structure: introduction, methods, results, discussion/ conclusions, notes, acknowledgments and bibliographical references.

The inclusion of references is mandatory, while notes and acknowledgments are optional. The correct citation will be assessed according to the 7 th edition of the APA standards.

\section{ETHICAL RESPONSIBILITIES}

Previously published material is not accepted (they must be unpublished works). The list of signatory authors should include only and exclusively those who have contributed intellectually (authorship), with a maximum of 4 authors per work. Articles that do not strictly comply with the standards are not accepted.

\section{STATISTICAL INFORMATION ON ACCEPTANCE AND INTERNATIONALIZATION FEES}

- Number of accepted papers published: 5 .

- Level of acceptance of manuscripts in this number: 71,4\%.

- Level of rejection of manuscripts: $28,6 \%$.

- Internationalization of authors: 3 countries (Peru, Pakistan and South Africa).

Guidelines for authors: https://www.3ciencias.com/en/regulations/instructions/ 


\section{INDEXACIONES INDEXATIONS}

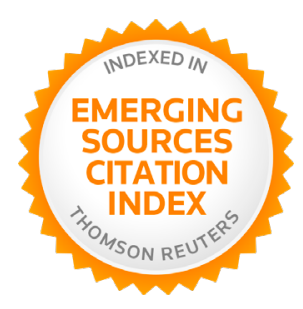

latindex
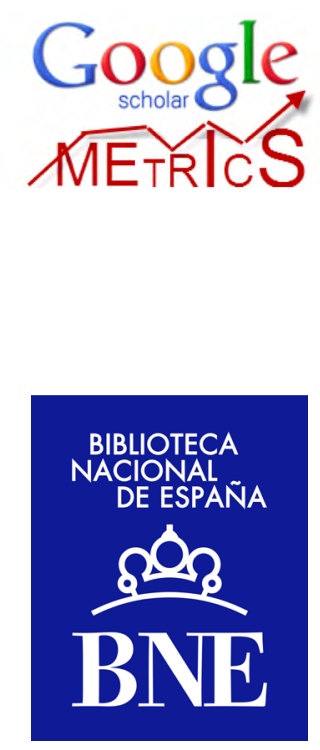

EBSCOhost

DULCINEA

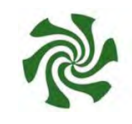

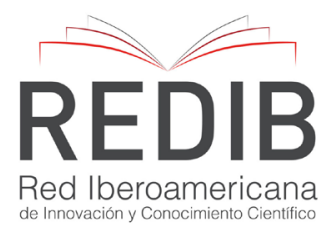

: ㄴ.

\section{ERIHPIJV}

o SHERPA/RoMEO 


\section{INDEXACIONES INDEXATIONS}

\section{- Dialnet}
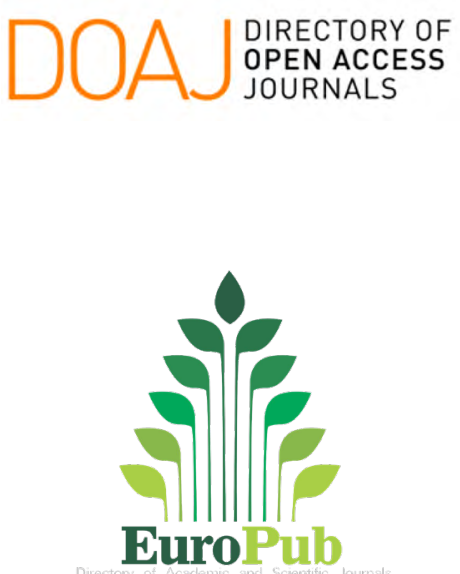

CSIC

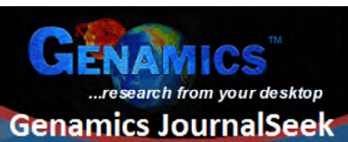

Genamics JournalSeek

Crossref

\section{ÍnDICEs}

\author{
ST WorldCat
}

\author{
IEIWORLD \\ $1 \oplus 1$ IOUURNALS
}




\section{/SUMARIO/ /SUMMARY/}


The architect member of the supervisory team in the construction of multifamily buildings

Felix David Avila Arguedas, Roberto Valdivia Sagastegui, Jorge Eduardo Injante Huarancca y Doris Esenarro Vargas

Qualitative benchmarking study of software for switch performance evaluation

Ángel Bernardo Julca Coscol, Christian David Tapia Prado, Francisco Manuel Hilario Falcón y Cheyer Marcelino Corpus Giraldo

Center of territorial domains and the network of the inca road - Qhapaq Nan, in the province of Tumbes - Peru

Model electric car with wireless charging using solar energy

Muhammad Osama Horani, Mariya Najeeb y Atif Saeed

Remotely measuring and controlling specific parameters of a PV module via an RF link Ntombizanele Maqache y Arthur James Swart 


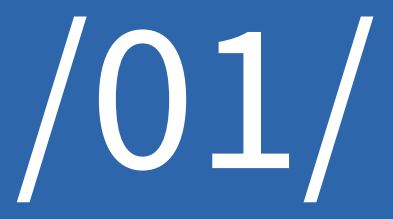




\title{
THE ARCHITECT MEMBER OF THE SUPERVISORY TEAM IN THE CONSTRUCTION OF MULTIFAMILY BUILDINGS
}

\author{
Felix David Avila Arguedas \\ Universidad Nacional Federico Villarreal, (Peru). \\ E-mail: favila@unfv.edu.pe ORCID: https://orcid.org/0000-0002-2870-4232
}

Roberto Valdivia Sagastegui

Universidad Nacional Federico Villarreal, (Peru).

E-mail: rvaldivia@unfv.edu.pe ORCID: https://orcid.org/0000-0003-3518-0454

Jorge Eduardo Injante Huarancca

Universidad Nacional Federico Villarreal, (Peru).

E-mail: 2017054954@unfv.edu.pe ORCID: https://orcid.org/0000-0003-2299-4897

Doris Esenarro Vargas

Universidad Nacional Federico Villarreal, (Peru).

E-mail: desenarro@unfv.edu.pe ORCID: https://orcid.org/0000-0002-3942-7832

Recepción: 04/08/2021 Aceptación: 12/11/2021 Publicación: 14/12/2021

\section{Citación sugerida:}

Avila, F. D., Sagastegui, R. V., Injante, J. E., y Vargas, D. E. (2021). The architect member of the supervisory team in the construction of multifamily buildings. 3C Tecnología. Glosas de innovación aplicadas a la pyme, 10(4), 17-33. https://doi. org/10.17993/3ctecno/2021.v10n4e40.17-33 


\section{ABSTRACT}

This research aims to determine the incidence of the architect of the supervisory team in the conformity of work in multifamily buildings in 2019, allowing us to see the participation of the architect as a supervisor in the results and how their participation influences. The methodology used is composed of a non-experimental type of research, a mixed approach because it is qualitative and quantitative with a descriptive correlational scope; through the observation of items and the use of surveys, with a sample of 47 multi-family buildings. According to the results obtained from the statistical process, the confirmation of the general hypothesis with a correlation of $(0.715)$ is mentioned, in the same way in the case of trace control and stakeout with a correlation of (0.838); of the fixed finishes of (0.798) and the non-fixed finishes with a correlation of (0.870). Finally, it is concluded that the architect's role as a supervisor is a function that can be carried out in work to achieve the conformity of a piece of multifamily buildings and the control of the line and the disposition elements Fixed. Non-fixed finishes are related and influence the decrease in observations on the variation of measurements and dimensions in the quality and conformity of the work of multi-family buildings.

\section{KEYWORDS}

Work supervision, Multifamily buildings, Supervisory team, Supervising architect, Fixed and non-fixed finishes to the structure. 


\section{INTRODUCTION}

Construction in Peru has been linked to countless problems, from those that arise at the beginning of a building to the regularization due to informality or modifications.

Suppose we can pay attention to this problem. In that case, we see that the need to build is linked to the need for housing and property ownership, leading to investing a lot of money from the beginning to its completion and formalization (20 Minutos Editora S. L., 2019).

If we understand the significant investment or expense that it generates, we do not know why not all due attention is given to the construction of buildings in the private sector; it is only regulated by laws, formulating regulations, or delegating responsibilities to professional associations or municipalities to supervise this construction activity. As a result of this activity, the real estate, carried out by many construction or real estate companies dedicated to this area, becomes a work with a series of questions, which does not transcend or are not known (ADI PERU, 2018).

Faced with this reality, we see that the informality in the construction and the lack of supervision during its construction is what is perceived, where most of the companies become judge and party, by supervising themselves, and in others, this activity does not even exist as part of their organization; in some cases, the development of the work is delegated to a resident, being the execution in many cases carried out by third parties or subcontractors. These companies seek to gain time and achieve the lowest possible cost, which will often result in non-compliance with regulations and correct construction procedures, leading to work with deficiencies and non-compliance with what was agreed with the client.

One of the factors, and we believe that it is the most crucial factor contributing to the success of a work, is synergic and permanent work supervision. This group must be professional, ethical, and specialized in controlling all the processes carried out during the construction of a building, in this case, a multifamily building (Barbaran, 2018). 
The supervision of works in multifamily buildings is a very delicate activity. It requires to be analyzed from several angles, from the point of view of the employer and/or real estate, the builder or executor, the supervisor of the work, the entities that control the building, such as municipalities, central government, and professional associations, as well as the future use of this building, should also participate (Alvarez, 2018).

The supervision of construction work in buildings is an activity that, due to its complexity, requires the participation of more than one specialist to be carried out properly; at present, in buildings constructed by private investment, the district municipalities are responsible for the control of this activity, through their inspection areas or the technical supervisors appointed by the engineering or architectural associations. If we talk about private companies, it should be noted that very few companies allocate investment to supervise the construction work.

In most of the buildings of private investment, it is the resident of work the one in charge of the supervision of work, becoming the supervisor of the tasks executed by him.

Supervising works in multifamily buildings is an essential activity due to the investment involved in executing the job and its social importance. It is necessary to control and keep statistics of all the tasks performed during construction and how they were completed. If modifications to the original project, their causes, and how they were executed, this information should be available to any owner or future property user. But at present, this is not the case; there are no statistics on the results of this participation of the supervision, nor of the observations made by the users to the final product, which does not contribute to delivering work with guarantee and quality (Bohorquez et al., 2020). 


\section{METHOD}

\subsection{TYPE OF RESEARCH}

Descriptive: It is oriented to the knowledge of the professional architect as supervisor, and it will be investigated as it develops its activity in the district Miraflores in the year 2019. Its characteristics will be determined and, if they allow influencing the conformity of the work (Cardenas, 2019).

Correlational: It aims to determine the degree of incidence between the variables of the supervising architect and the conformity of the work.

\subsection{POPULATION AND SAMPLE}

The size is finite and will cover new multifamily buildings that conform to work by the Municipality of the district Miraflores, city of Metropolitan Lima, in 2019. Therefore, the indicated data have been obtained from the same municipality of Miraflores, where the conformity of work delivered to multifamily buildings from January to December 2019 has been collected for each month, bringing the following data:

The "sample will be a significant representation of the population" of multifamily buildings with work conformity in the district of Miraflores, province of Lima, under the assumption of a $5 \%$ error; we will study the characteristics of this set (Carretero \& Moreno, 2019).

To find the "finite population sample size," the formula 1 shown below will be used:

It is necessary to define the "Confidence level" ( $\mathbf{Z}$ ) and "Absolute precision level" (d) for the equation shown above, based on the "experimental certainty level", shown in the following lines:

For the present investigation, we have $\mathrm{N}=53$ buildings.

The values of $p=0.5 q=0.5$ are assumed. 
From the above table, a $\mathrm{C}=95 \%(\mathrm{~d}=5 \%)$ is assumed, with a

$\mathrm{Z}=1.96$

Next, the values are replaced in the equation that was initially shown. Thus we have:

$$
n=\left[\frac{(53) *(1.96)^{2} *(0.5) *(0.5)}{(0.05)^{2} *(53-1)+(1.96)^{2} *(0.5) *(0.5)}\right]=46.6812179
$$

Rounding up our sample $=47$ multifamily buildings.

\section{RESULTS}

In this section, we can visualize the results of the survey taken from 47 participants, specifying the importance and incidence of the architect in the conformity of work in multifamily buildings in the district of Miraflores, all of this for its interpretation.

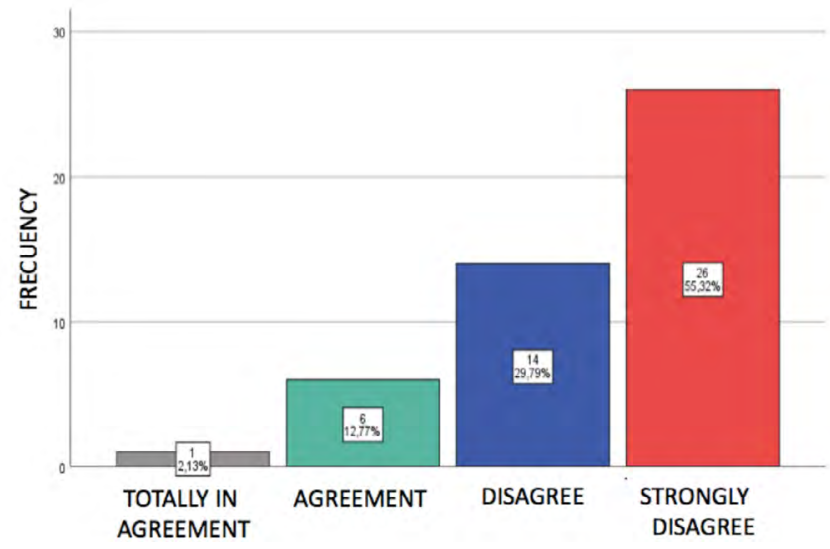

Figure 1. Graph of the question "A team is required for site supervision.".

Source: own elaboration. 
According to Figure 1, of the 47 respondents, more than half of them "Strongly agree" $26(55.3 \%)$ that a team is required for construction supervision, 14 (29.8\%) "Agree", 6 (12.8\%) "Disagree" and 1 $(2.1 \%)$ "Strongly disagree"; that is, more than half of the participants show that it is essential to have a construction supervision team in multifamily buildings (EcuRed, 2018).

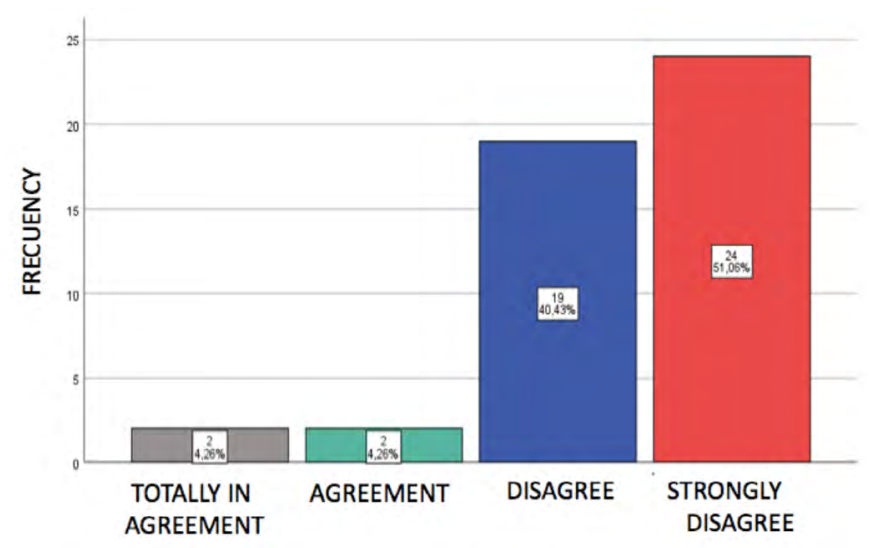

Figure 2. Graph of the question "The architect should be the supervisor of the architecture specialty."

Source: own elaboration.

Regarding Figure 2, that the participants, 24 (51.1\%) "Strongly agree" that the architect should be the supervisor of the architecture specialty, 19 (40.4\%) "Agree," 2 (4.3\%) "Indifferent," 2 (4.3\%) "Strongly disagree"; that is, they consider the specialty necessary at the time of supervision in the area of architecture. 


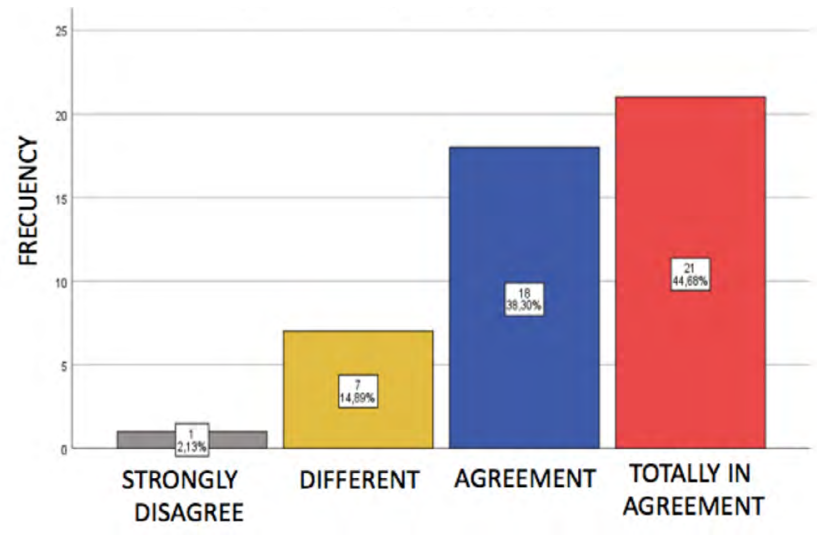

Figure 3. Graph of the question "The architect should be part of the supervision team".

\section{Source: own elaboration.}

Regarding Figure 3, of the participants, 21 (44.7\%) are "Strongly agree," 18 (38.3\%) "Agree," 7 (14.9\%) "Indifferent," 1 (2.1\%) "Strongly disagree"; i.e., the majority considers that the participation of the architect in the supervisory team is essential for the compliance of work, offering a more multidisciplinary team, with different perspectives (Davila, 2019).

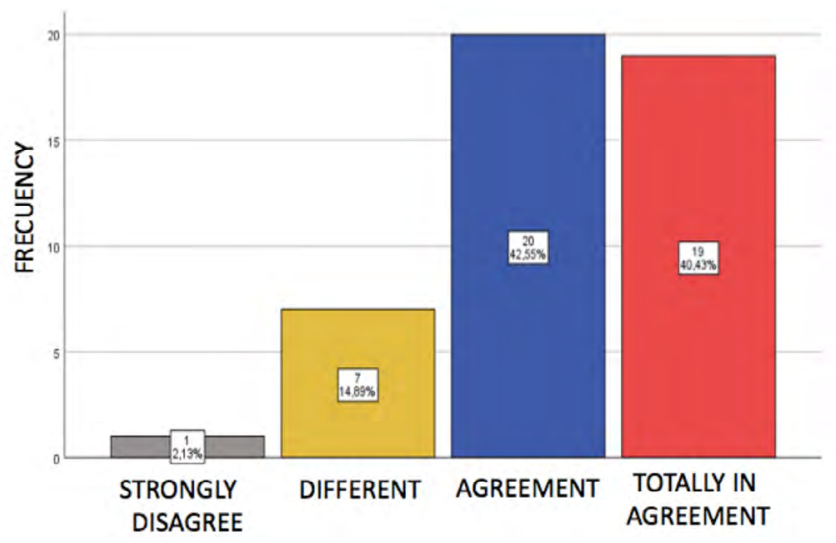

Figure 4. Graph of the question "This item affects the quality of the work.".

Source: own elaboration. 
According to Figure 4, the answer that stood out is "Strongly agree" and "Agree", with 20 (42.6\%) for both solutions, followed by $7(14.9 \%)$ "Indifferent" and $1(2.1 \%)$ "Strongly disagree" concerning the control of the drawing and stakeout items for the quality of work and that leads to the conformity of the work, decreasing the observations on the variation of measures and dimensions of the rooms of the real estate unit (El Comercio, 2018).

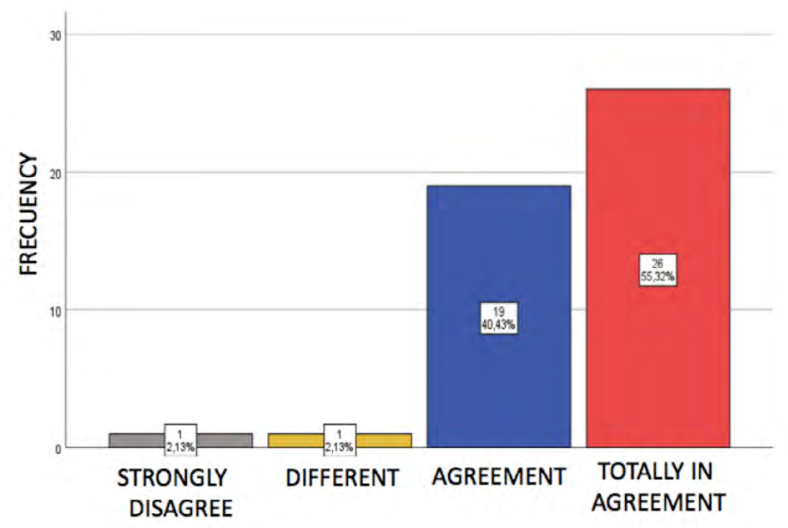

Figure 5. Graph of the question "This item affects the quality of the work".

Source: own elaboration.

In Figure 5 shows that the answer that stands out is "Strongly agree" 26 (55.3\%), "Agree" 19 (40.4\%), "Indifferent" 1 (2.1\%), and "Strongly disagree" both with 1 (2.1\%); that is, the control of the finishes fixed to the structure achieves a decrease in the observations to the conformity of work, which affects the agreement of work in multifamily buildings. (Fernandez, Moyano, \& Chaza, 2019). 


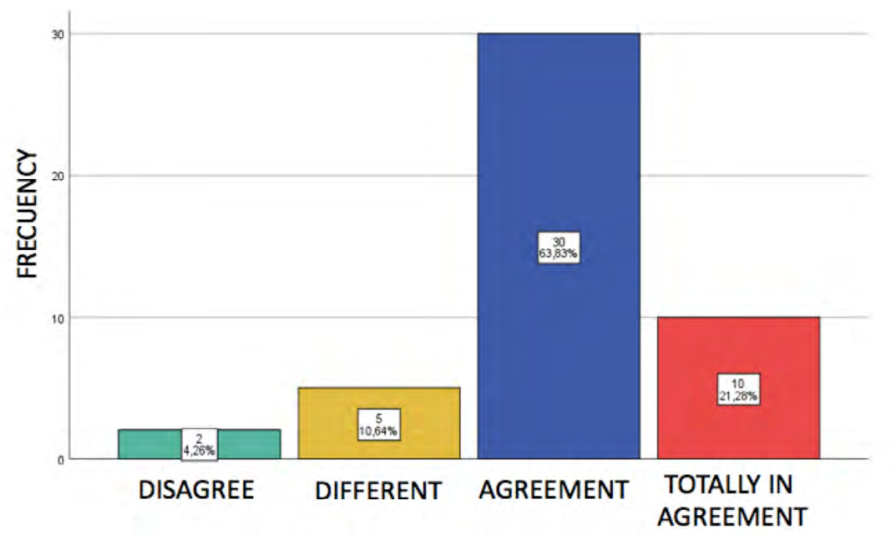

Figure 6. Graph of the question "Should the architect participate in the items (scaffolding and veneer)."

Source: own elaboration.

According to Figure 6, has as the most definitive answer "Agree" with 30 (63.8\%), followed by "Strongly agree" 10 (21.3\%), "Indifferent" 5 (10.5\%), "Disagree" 2 (4.3\%), this shows that the participation of the architect of the supervising team is essential in the control of items of fixed finishes to the structure (tiling and veneers), thus decreasing the observations (Flores, 2019).

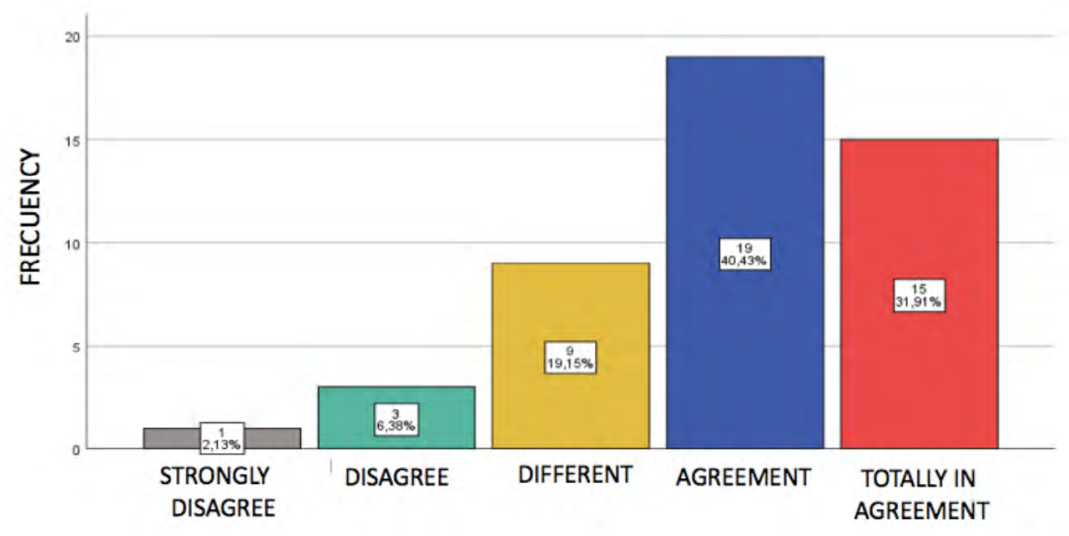

Figure 7. Graph of the question "This item affects the quality of the work".

Source: own elaboration. 
According to the present Figure 7, the answers of the respondents show "Agree" 19 (40.4\%), "Strongly agree" 15 (31.9\%), "Indifferent" 9 (19.1\%), "Disagree" 3 (6.4\%), and "Strongly disagree" 1 (2.1\%). These data show us that the quality of work also depends on the control of the fixed finishing items, consequently, the conformity of the work (Hernandez et al., 2020).

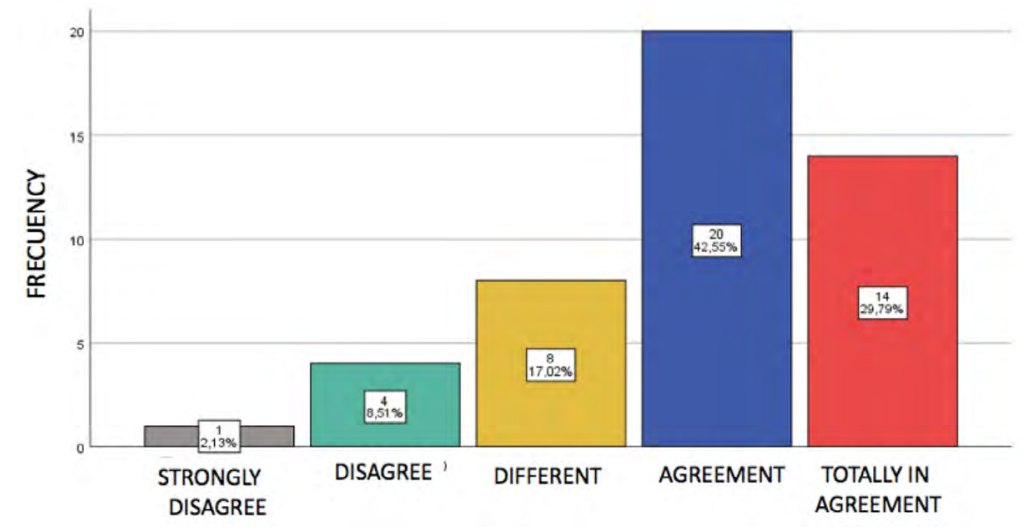

Figure 8: Graph of the question "Should the architect participate in the carpentry of openings, floors, furniture."

Source: own elaboration.

Regarding Figure 8, the results obtained are 17, "Agree" 20 (42.6\%), "Strongly agree" 14 (29.8\%), "Disagree" 8 (17.0\%), "Disagree" 4 (8.5\%), and "Strongly disagree" 1 (2.1\%), which leads us to conclude that the architect's participation in the control of carpentry items is essential for the conformity of a work (Hernandez, 2018).

\section{DISCUSSIONS}

According to the first objective of determining the incidence of the architect of the supervisory team in the compliance of work, it was obtained as a result that the architect of the supervisory team directly affects the submission of work in multifamily buildings in the district of Miraflores in the city of Metropolitan Lima, in the year 2019, with a considerable positive correlation. 
With the above mentioned, the studies found either national and international, which precede this work, do not present a direct relationship because the work is novel that seeks to propose the architect as supervisor (Lengua, 2018).

Therefore, the investigations that partially coincide with the research are the following: architects and future construction professionals cannot be left aside, it is necessary to contribute supported by a strong sense of responsibility, obtaining the best results in the activities that have been entrusted to them, making in turn, more efficient the personnel in their charge (Vela et al., 2021).

In the case of the specific objectives, the result obtained from the first clear objective: the control of the layout and stakeout items have a favorable impact on the conformity of a multifamily building, with a significant positive association" between the two variables, this coincides with "the adequate control of the layout and stakeout items in the value of the building works, which generally is not given due importance, perhaps due to ignorance of some indicators or references that allow quantifying it, which emphasizes the importance of controlling these items to minimize losses either economic or time, which falls on the conformity of the work (Pacheco, 2020).

According to the second specific objective, to analyze the incidence of the control of the items of fixed finishes in the conformity of a multifamily building, its result was that the power of the things of appointed finishes to the structure generates a positive incidence in the agreement of a multifamily building being these variables correlative (Reyes, 2018).

The close relationship between the company and the subcontractor and the trim control in the supervision give rise to non-compliance with the deadline and a preliminary order of the various items of finishes, this reaffirms the research on management of the things, for the best quality of work, as well as the conformity of this and the support of the architect, is a proposal that would help in the control of the items as a supervising professional (Rodriguez \& Sanchez, 2019). 
Finally, the third objective that seeks to examine the incidence of the control of the non-fixed finishes items to the structure in the conformity of the client of a multifamily building, obtained. As a result, the power of the non-fixed finishes items to the design affects positively in the unity of a multifamily building, and that keeps a robust positive correlation between the non-fixed finishes to the system with the agreement of the work; The research that supports this assertion, the study conducted on the four items reveals that in the finishing phase there is a large inventory of partial products with up to one month of waiting time. It should be decided to prioritize the activities and place some of them at the end of the schedule so that there are no long waits. Set clear goals to reduce waiting times, i.e., this involves, directly and indirectly, the control of these items for the efficiency of all these requirements that need the finishes, whether fixed or not fixed, with the supervision of an architect who has the capacity for this purpose (Villanueva et al., 2021).

\section{CONCLUSIONS}

The association of the architect of the supervisory team and the compliance of work in multifamily buildings presented a result of 0.715 evidenced by the answers given by the participants, which are mentioned below: "A team is required for site supervision", the responses that most highlighted "agree" and "strongly agree" (29.8\% and 55.3\%) respectively; "The team should be permanently on site" (36.2\% and 40.4\%); "The architect should be the supervisor of the architectural specialty" (40.4\% and 51.1\%); "Does the architect have the academic training to be part of the supervisory team" (46.8\% and 29.8\%); "The architect should be part of the supervisory team" (38.3\% and 44.7\%); "He has an impact on the compliance of the work" $(63.8 \%)$ and for the question "His participation would delay the work" the answers that stood out the most were "totally disagree" and "disagree" (44.7\% and 36.2\%) respectively. This shows that the architect's role as a supervisor is a function that can be carried out on a construction site to achieve compliance in multifamily buildings. This as a proposal of involvement or action of the architect as the person in charge of the supervisory area; therefore, he must be adequately trained and prepared for any case or problem that may occur and be solved efficiently. 
Although the architect has a preconceived misconception that he is only for architectural design, part of his training is to supervise and control the project from beginning to end, construction planning, etc. This makes him a person professionally capable of generally developing in the supervision of multifamily buildings.

In the case of correlation of control of the items of layout and stakeout for the conformity of work of multifamily buildings, it shows an association of 0.838 , evidenced by the questions related to these variables, such as the following: "The item has an impact on the quality of the work", the answers that stood out the most were "agree" and "totally agree" (42.6\% and 40.4\%) respectively; "The architect should participate in the initial layout of the work" (36.2\% and 19.1\%); "He should participate in the other stakeout items during the work" (53.2\% and 12.8\%); "These items have an impact on the conformity of the work" ( $55.3 \%$ and $8.5 \%$ ). Therefore, it is essential to consider that planning involves the quality of work and the reduction of observations on the variation of measures and dimensions of the real estate unit rooms that make the project compatible with the work area. Therefore, reasonable control and supervision in this phase directly impact the conformity of the work.

Regarding the association between the control of the items of fixed finishes to the structure and the conformity of the work, a correlation of 0.798 was obtained, evidenced by the questions related to these variables, such as the following: "This item affects the quality of work", the answers that stood out the most were "agree" and "totally agree" (40.4\% and 55.3\%) respectively; "The architect should participate in the items (Tarrajeo and veneers)" (63.8\% and 21.3\%); "These items have an impact on the conformity of the work" (63.8\% and 14.9\%); for the question "If he participates, he should be permanent", the answers that stood out the most were "indifferent" and "agree" (25.5\% and 8.5\%) respectively. This shows a decrease of observations in the process of work compliance, which involves the execution and deficient finishes of walls, floors, and ceilings and affects work compliance and the quality of multifamily buildings achieved based on the individual supervision either by the architect. 
In conclusion, according to the correlation between the variable of control of the items of non-fixed finishes to the structure and conformity of work of multifamily buildings, the figure obtained was 0.870 , which is supported by the following questions: "Does this item have an impact on the quality of the work", with a higher percentage of "agree" and "totally agree" answers (40.4\% and 31.9\%) respectively; "Should the architect participate in the items of carpentry in openings, floors, furniture" (42.6\% and 29.8\%); "In the case of the question "If he participates, he should be permanently on-site", the most important answers were "indifferent" and "in agreement" (46.8\% and 25.5\%). The shows mentioned above that the control of the non-fixed finishing items to the structure, although it is a final part of the construction process, its supervision is essential, since it decreases the observations of the owner, as well as increases the quality of the work, complying with the requirements in the building and of course reaching the conformity of the work, for the satisfaction of both the company and the client.

\section{REFERENCES}

20 Minutos Editora S. L. (2019). Aplican penas a contratistas por obras mal ejecutadas en Tijuana. 20 Minutos. https:/ /www.20minutos.com.mx/noticia/466782/0/aplican-penas-a-contratistas-por-obrasmal-ejecutadas-en-tijuana/

ADI PERÚ. (2018). Surquillo con potencial para grandes proyectos. ADI PERÚ. https://adiperu.pe/noticias/ surquillo-con-potencial-para-grandes-proyectos/

Álvarez, M. (2018). A pie de obra. Descubriendo los secretos de la construcción. Universidad Politécnica de Valencia.

Barbaran, C. (2018). Aplicación de mapeo de cadenas de valor en la etapa de acabados en un edificio multifamiliar (Tesis). Pontificia Universidad Catolica del Perú. 
Bohorquez, F., Esenarro, D., Rodriguez, G., Tafur, V., \& Tafur, G.(2020) Modular construction camp as an architectural model and its different construction systems - Moquegua, Perú 2020, Materials Today: Proceedings. https://doi.org/10.1016/j.matpr.2021.04.399

Cardenas, Y. (2019). Alcalde de Lince: "Los vecinos sienten que se está perdiendo la residencialidad". Semana Económica. https://semanaeconomica.com/legal-politica/sector-publico/358968-alcalde-delince-los-vecinos-sienten-que-se-esta-perdiendo-la-residencialidad-del-distrito

Carretero, M. J., \& Moreno, A. (2019). Cuantificación porcentual de los daños existentes en los revestimientos interiores de las viviendas españolas. Informes de la Construcción, 71(555). https:// doi. org/10.3989/ic.65059

Dávila, I. (2019). Certifican en Edomex a directores de obras. La Jornada, pág. 28. https://www.jornada.com. $\mathrm{mx} / 2019 / 01 / 25 /$ estados/028n lest

EcuRed. (2018). Arquitecto. https: / / www.ecured.cu/index.php?title=Arquitecto\&oldid=3177696

El Comercio. (2018). Barranco no detiene su explosión inmobiliaria. https://elcomercio.pe/economia/peru/ barranco-detiene-explosion-inmobiliaria-noticia-564975-noticia/

Fernández, P., Moyano, J., \& Chaza, M. (2019). Gestión de riesgos de costes de posconstrucción en edificios residenciales en alquiler. Informes de la Construcción, 71(555). https://doi.org/10.3989/ ic.63759

Flores, L. (2019). Se llamará a cuentas a las constructoras que incumplan: César Cravioto. Diario La Jornada, pág. 29. https://www.jornada.com.mx/2019/04/17/capital/029n1cap

Hernandez, F., Esenarro, D, Rodriguez, G., Vela, L., \& Calvo, R. (2020) Earned Value Method Management Applied to The Construction of The Multifamily Building - Lima, Peru 2020. Fournal of Contemporary Issues in Business and Government, 27(3), 838-848. https://doi.org/10.47750/ cibg.2021.27.03.117 
Hernandez, S. (2018). Publican lineamientos para rehabilitar edificios dañados por el 19-S. El Universal. https:// www.eluniversal.com.mx/metropoli/cdmx/publican-lineamientos-para-rehabilitar-edificiosdanados-por-el-19-s

Lengua, M. (2018). Proyecto inmobiliario de vivienda multifamiliar sostenible en el distrito de San Miguel. http:// tesis.pucp.edu.pe/repositorio/handle/123456789/11614

Pacheco, D. (2020). Pasion por el Derecho Corporation. https://lpderecho.pe/ley-regularizacion-edificacionesley-27157-actualizado/

Reyes, J. (2018). ADI/Peru/gestion. https:/ / gestion.pe/noticias/adi-peru

Rodríguez, M., \& Sánchez, E. (2019). Vivienda Vertical Social en la frontera norte de Mexico: criterios para una densificación sustentable. Revista invi, 34(95), 167-194.

Vela, L., Esenarro, D., Rodriguez, G., Hernandez, F., \& Calvo, R. (2021). Plan Grid in the Process of Purchasing Services in the Construction Site Nuevo Santa Clara Stage 4,5,6, Lima. Annals of R.S.C.B., 25(4), 12260 - 12266. https://www.annalsofrscb.ro/index.php/journal/article/ view/4149

Villanueva, O., Esenarr, D., Rodriguez, G., \& Guerra, P. (2021). Evaluation of the additional public infrastructures during the execution of the construction. Turkish Fournal of Computer and Mathematics Education, 12(10), 554-559 


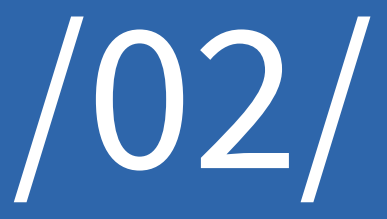




\title{
QUALITATIVE BENCHMARKING STUDY OF SOFTWARE FOR SWITCH PERFORMANCE EVALUATION
}

\author{
Ángel Bernardo Julca Coscol \\ University César Vallejo, (Peru). \\ E-mail: abjulcaj@ucvvirtual.edu.pe ORCID: https://orcid.org/0000-0002-2609-0214 \\ Ghristian David Tapia Prado \\ University César Vallejo, (Peru). \\ E-mail: ctapiapr87@ucvvirtual.edu.pe ORCID: https://orcid.org/0000-0003-4078-7015 \\ Francisco Manuel Hilario Falcón \\ University César Vallejo, (Peru). \\ E-mail: fhilariof@ucvvirtual.edu.pe ORCID: https:/ / orcid.org/0000-0003-3153-9343
}

Cheyer Marcelino Gorpus Giraldo

University César Vallejo, (Peru).

E-mail: cheyergc@gmail.com ORCID: https:// orcid.org/0000-0002-4024-8065

Recepción: 20/08/2021 Aceptación: 16/11/2021 Publicación: 14/12/2021

\section{Citación sugerida:}

Julca A. B., Tapia, C. D., Hilario, F. M., y Corpus, C. M. (2021). Qualitative benchmarking study of software for switch performance evaluation. 3C Tecnología. Glosas de innovación aplicadas a la pyme, 10(4), 35-49. https://doi. org/10.17993/3ctecno/2021.v10n4e40.35-49 


\section{ABSTRACT}

The objective of the research was to compare network software technologies to evaluate the performance of switches based on year of inception, countries implemented, versions, type of software, operating system, programming language, features, tools, benefits, and cost range of implementation. It was concluded that OpUtils is the licensed software with more experience in the market in the technological platforms based on the evaluation of the performance of the software to manage the switches being one of the national and international companies that had a great apogee for its low cost and its quality service. On the other hand, Open vSwitch is the software that shows a high-level index in terms of software updates that allow blocking errors in the source code and patches in poorly developed configurations and maintain security in the management of ports and interfaces for switches. This is due to the fact that the software is based on open-source code allowing to optimize its processes. Finally, it is possible to maintain high standards for privileged users, stop anomalies in real time and stop the cause of the problem is necessary to use a licensed software such as Cisco Open SDN Controller for its full functionality. Finally, some recommendations for future studies were indicated, such as: (a) to perform a classification research covering more than 6 switch management software to increase the alternatives for the selection of a complete software that meets the needs of the stakeholders, (b) to increase the number of variables with the aim of taking the research to a deeper study to provide the support to technical network administrators in the security of devices (switches).

\section{KEYWORDS}

OpenStack, Open vSwitch, OpenQRM, Cisco Open SDN controller, Ni switch executive, OpUtils. 


\section{INTRODUCTION}

Today, the greatest demand for networking organizations to structure traditional network architectures is for quality services. Therefore, for some time now, software-based networking technology platforms have been developed to evaluate the performance of ICT-enabled tools based on virtualization, enabling communication between devices, and maintaining predictable control between these systems. Also, the virtual switch is the backbone of all data center networks because companies employ tools in order to use software resources and have economical and complete networking solutions (Morillo, 2014; Nicolalde, 2021).

Likewise, hubs or switches can have rules created to avoid collisions or traffic increase through the network channels (Toapanta, 2006; Cujilema, 2011). Similarly, they can work at the same speed as all interconnected ports, facilitating the work of each device (Toapanta, 2006; Cujilema, 2011). However, they can make packet forwarding decisions based on specific addresses providing a higher bandwidth for each computer since their configuration is simple and maintains multiple protocols for data transfer in networks of different segmentation in order to end data congestion in the network (Toapanta, 2006; Cujilema, 2011).

In addition, the switch is a tool that has diverse functionalities to manage networks based on protocols that allow seamless communication between systems (Nicolalde, 2021). Therefore, for the evaluation of software it is necessary to perform stress or performance tests in search of various alternatives that can meet the access, scalability, network flexibility, data processing, security and process automation (Cardona, 2019). Regarding this, the switches are modern equipment and in essence those of CISCO can restrict ports and create security policies this is due to the software of the entity that allows to execute these actions when it detects anomalies within the network (Luna, 2019). In that sense, Valencia (2013) developed a graphical network diagram platform of different wiring systems in telephony headquarters to interact through switches in a LAN network allowing DHCP servers and DNS servers to obtain data from the hosts and display it in real time in the technological network diagram in order to manage 
anomalies or connection problems (Valencia, 2013; Cujilema, 2011).

In this research it is proposed to compare software for the evaluation of the performance of switches using free and licensed software based on indicators of previous studies in order to provide relevant information to entities of interest such as those responsible for handling and managing networks allowing them to make a decision based on characteristics that are more suited to the entity, likewise increases the rate of innovation based on software meeting the essential requirements of a software (security, quality of service, routing users, programmable and easy to manipulate) (Morillo, 2014; Valencia, 2013; Luna, 2019; Nicolalde, 2021).

\section{MATERIALS AND METHODS}

The purpose of this study was to compare free software and licensed software for network switch performance evaluation based on the following indicators: Year of inception, Countries Deployed, Versions, Software Type, Operating System, Programming Language, Features, Tools, Benefits and Implementation Cost Range.

The study was qualitative since it describes and defines software technologies to evaluate the performance of switches based on cross-sectional data mining (Sánchez, Fernández y Díaz, 2021). In this regard, Sanchez, Fernandez and Diaz (2021) mentioned that qualitative research has an important potential before society since it is methodology, processes, procedures of concrete and particular performance when collecting data since being evident that it is a technique of greater depth of search. In addition, the design of the study has been topical, with the objective of reaching the specialists or technical managers who make the decision to opt for optimal and quality systems that meet the requirements for the entity. Several researches were evaluated in Scopus, Dyna, EBSCO, Scielo, Elsevier and the technical data of suppliers of these software's focused on switches (Sánchez, Fernández y Díaz, 2021). 


\section{RESULTS}

After detailing the comparative tables of free software and licensed software for the evaluation of switch performance, the most influential characteristics are compared with the results of previous research in order to obtain a similarity, difference and/or comparison with the present study. Likewise, when carrying out the structure of free software and licensed software, it is possible to identify similarities and/or differences found in the indicators selected in the present study with the results of previous research. Therefore, the comparison of data extracted in the comparative tables is shown, disagreed and/or justified. Likewise, it could be observed in the results, that the OpUtils software shows many years of antiquity in the technological and labor market. In this way, it has approximately 25 years in the dedication and practice to offer solutions to users, network administrators who use software for the management and monitoring of switches, where this result shows the difference in the work of Martinez, Valencia and Osorio (2010) where they justified as a result that the Cacti and Nagios software are those technological platforms that currently predominate the operation of the system in the face of anomalies.

On the other hand, the Open vSwitch software versions prove to be constant developments by performing updates in short periods, with the aim of correcting bugs, errors and bad structure in the source code, to maintain security and information in users, this result shows similarity by Pfaff et al. (2015) where they justified as a result that it is advisable to use the Open vSwitch software given the large-scale increase on the variability in the flow and optimization routes to minimize these problems by reducing changes in the software (Pfaff et al., 2015). In addition, OpUtils software is able to adapt to any operating system (Windows and Linux) since its software distributions are easy to install and monitor, this result shows difference to Melwani's work where he mentioned as a result that virtualization is more efficient since its libraries and dependencies, are helpful in creating Docker containers instead of existing as a complete operating system, only including the binaries, necessary libraries and the software we want to virtualize (Melwani, 2018). 
Table 1. Comparison of open-source software for switch performance evaluation.

\begin{tabular}{|c|c|c|c|}
\hline \multirow{2}{*}{ INDICATORS } & \multicolumn{3}{|c|}{ SOFTWARE } \\
\hline & OpenStack & Open vSwitch & OpenQRM \\
\hline START YEAR & $\begin{array}{l}\text { In } 2010 \text { the software was } \\
\text { released for the first time } \\
\text { (OpenStack, 2020). }\end{array}$ & $\begin{array}{l}\text { The foundation of the } \\
\text { software is in } 2009 \\
\text { (Open vSwitch, 2020). }\end{array}$ & $\begin{array}{l}\text { The founding year of } \\
\text { the software was } 2004 \\
\text { (OpenQRM, 2021). }\end{array}$ \\
\hline $\begin{array}{l}\text { COUNTRIES } \\
\text { IMPLEMENTED }\end{array}$ & $\begin{array}{c}\text { United States } \\
\text { (OpenStack, 2020). }\end{array}$ & $\begin{array}{c}\text { United States } \\
\text { (Open vSwitch, 2020). }\end{array}$ & $\begin{array}{l}\text { Australia, Germany } \\
\text { (Cardona, 2019). }\end{array}$ \\
\hline VERSIONS & $\begin{array}{l}\text { Ussuri, Train, Stein, Rocky, } \\
\text { Queens, Pike, Ocata, } \\
\text { Newton, Mitaka, Liberty, Kilo, } \\
\text { Juno, Icehouse, Havana, } \\
\text { Grizzly, Folsom, Essex, } \\
\text { Diablo, Cactus, Bexar, Austin } \\
\text { (OpenStack, 2020). }\end{array}$ & $\begin{array}{c}\text { v2.15.0, v2.14.2, v2.14.1, } \\
\text { v2.14.0, v2.13.3, v2.13.2, } \\
\text { v2.13.1, v2.13.0, v2.12.3, } \\
\text { v2.12.2, v2.12.1, v2.12.0, } \\
\text { v2.11.7, v2.11.6, v2.11.5, } \\
\text { v2.11.4, v2.11.3, v2.11.2, } \\
\text { v2.11.1, v2.11.0, v2.10.7, } \\
\text { v2.10.6, v2.10.5, v2.10.4, } \\
\text { v2.10.3, v2.10.2, v2.10.1, } \\
\text { v2.10.0, v2.9.9, v2.9.8, } \\
\text { v2.9.7, v2.9.6, v2.9.5, v2.9.4, } \\
\text { v2.9.3, v2.9.2, v2.9.1, v2.9.0, } \\
\text { v2.8.11, v2.8.10, v2.8.9, } \\
\text { v2.8.8, v2.8.7, v2.8.6, v2.8.5, } \\
\text { v2.8.4, v2.8.3, v2.8.2, v2.8.1, } \\
\text { v2.8.0, v2.7.13, v2.7.12, } \\
\text { v2.7.11, v2.7.10, v2.7.9, } \\
\text { v2.7.8, v2.7.7, v2.7.6, v2.7.5, } \\
\text { v2.7.4, v2.7.3, v2.7.2, v2.7.1, } \\
\text { v2.7.0, v2.6.10, v2.6.9, } \\
\text { v2.6.8, v2.6.7, v2.6.6, v2.6.5, } \\
\text { v2.6.4, v2.6.3, v2.6.2, v2.6.1, } \\
\text { v2.6.0, v2.5.12, v2.5.11, } \\
\text { v2.5.10, v2.5.9, v2.5.8, } \\
\text { v2 } 5.7, \text { v2.5.6, v2.5.5, v2.5.4, } \\
\text { v2.5.3, v2.5.2, v2.5.1, v2.5.0, } \\
\text { v2.4.0, v2.3.2, v2.3.1, v2.3.0, } \\
\text { v2.1.2, v2.1.1, v2.1.0, v2.0.0, } \\
\text { v1.11.0, v1.10.0, v1.9.0, } \\
\text { v1.7.0, v1.6.1, v1.5.0, v1.4.2, } \\
\text { v1.4.1, v1.4.0, v1.3.0 } \\
\text { (Open vSwitch, 2020). }\end{array}$ & $\begin{array}{l}\text { v.5.3.40, v.5.3.8, v.5.3.5, } \\
\text { v.5.3.2, v.5.3.1, v.5.0.2, } \\
\text { v.4.7, v.4.6, v.4.5, } \\
\text { v.4.4, v.4.3, v. } 4.2, \text { v.4.1 } \\
\text { (OpenQRM, } 2021 \text { ). }\end{array}$ \\
\hline TYPE OF SOFTWARE & $\begin{array}{l}\text { Free software } \\
\text { (Garcia, 2020). }\end{array}$ & $\begin{array}{c}\text { Free Software } \\
\text { (Open vSwitch, 2020). }\end{array}$ & $\begin{array}{c}\text { Free software } \\
\text { (OpenQRM, 2021). }\end{array}$ \\
\hline
\end{tabular}




\begin{tabular}{|c|c|c|c|}
\hline \multirow{2}{*}{ INDICATORS } & \multicolumn{3}{|c|}{ SOFTWARE } \\
\hline & OpenStack & Open vSwitch & OpenQRM \\
\hline OPERATING SYSTEM & $\begin{array}{c}\text { GNU/Linux } \\
\text { (OpenStack, 2020). }\end{array}$ & $\begin{array}{c}\text { GNU/Linux BSD } \\
\text { (Open vSwitch, 2020). }\end{array}$ & $\begin{array}{c}\text { GNU/ Linux } \\
\text { (Gómez, 2013). }\end{array}$ \\
\hline $\begin{array}{l}\text { PROGRAMMING } \\
\text { LANGUAGE }\end{array}$ & $\begin{array}{c}\text { Python } \\
\text { (Garcia, 2020). }\end{array}$ & $\begin{array}{c}\text { Python } \\
\text { (Melwani, 2018). }\end{array}$ & $\begin{array}{c}\text { C, PHP, JAVA } \\
\text { (OpenQRM, 2021). }\end{array}$ \\
\hline CHARACTERISTICS & $\begin{array}{l}\text { It constitutes a network } \\
\text { infrastructure where it is } \\
\text { possible to manage IP } \\
\text { addresses and generate } \\
\text { virtual networks where there } \\
\text { is compatibility with neutron. } \\
\text { Also, the software has a } \\
\text { firewall implementation in the } \\
\text { network with neutron } \\
\text { (Garcia, 2020). }\end{array}$ & $\begin{array}{l}\text { The database information is } \\
\text { protected in new software } \\
\text { updates. On the other hand, } \\
\text { the control configuration in } \\
\text { the kernel module is called. } \\
\text { In such a way, it manages } \\
\text { the control of data flow } \\
\text { between bridges for virtual } \\
\text { interfaces. It also has a } \\
\text { high level of control for the } \\
\text { software service } \\
\text { (Open vSwitch, 2020). }\end{array}$ & $\begin{array}{l}\text { It contains different } \\
\text { virtualization points for IT } \\
\text { support. Also, the software } \\
\text { automates the configuration } \\
\text { automatically under its } \\
\text { entirety } \\
\text { (Gómez, 2013). }\end{array}$ \\
\hline TOOLS & $\begin{array}{l}\text { NetFlow SPAN, RSPAN, } \\
\text { LACP, y 802.1q } \\
\text { (Garcia, 2020). }\end{array}$ & $\begin{array}{l}\text { The domain configuration is } \\
\text { based on the kernel module } \\
\text { control. Thus, it is managed } \\
\text { in the virtual interfaces of } \\
\text { the switches. Likewise, } \\
\text { the control of the data flow } \\
\text { between bridges } \\
\text { (Melwani, 2018). }\end{array}$ & $\begin{array}{l}\text { Virtual machines such as } \\
\text { Debian GNU/Linux, Ubuntu } \\
\text { Linux, CentOS, SuSE/SLES, } \\
\text { Fedora } 9 \text { are used to use } \\
\text { the tools } \\
\text { (OpenQRM, 2021). }\end{array}$ \\
\hline BENEFITS & $\begin{array}{l}\text { It contains a high level of } \\
\text { data security and reliability. } \\
\text { In addition, it acquires a high } \\
\text { distribution and acceptance } \\
\text { in the IP address. Thus, it is } \\
\text { possible to have virtualization } \\
\text { under IP addresses in } \\
\text { Neutron } \\
\text { (OpenStack, 2020). }\end{array}$ & $\begin{array}{l}\text { The network functionality } \\
\text { is incorporated into the } \\
\text { various access points. In } \\
\text { this way, the OVS software } \\
\text { is constituted in two } \\
\text { configurable flow modes in } \\
\text { OVSDB and OpensFlow. } \\
\text { Also, the software is based } \\
\text { on having a compatibility in } \\
\text { bridges } \\
\text { (Open vSwitch, 2020). }\end{array}$ & $\begin{array}{l}\text { It performs in having variety } \\
\text { of plugins in the software } \\
\text { functionality such as the } \\
\text { basics of a DHCP, TFTP } \\
\text { and Local Server. Also, it } \\
\text { manages virtual resources } \\
\text { in plugin activation where it } \\
\text { is mentioned with Xen and } \\
\text { Storage-Xen } \\
\text { (OpenQRM, 2021). }\end{array}$ \\
\hline
\end{tabular}

Source: own elaboration. 
Table 2. Comparison of licensed software for switch performance evaluation.

\begin{tabular}{|c|c|c|c|}
\hline \multirow[b]{2}{*}{ INDICATORS } & \multicolumn{3}{|c|}{ SOFTWARE } \\
\hline & $\begin{array}{c}\text { Cisco Open SDN Controller } \\
\text { (Cisco Open SDN Controller, } \\
\text { 2014). }\end{array}$ & NI Switch Executive. & OpUtils. \\
\hline START YEAR & $\begin{array}{l}\text { In the foundation year of the } \\
\text { proposed software was } 2014 \\
\text { (Cisco Open SDN Controller, } \\
\text { 2014). }\end{array}$ & $\begin{array}{l}\text { The year the software was } \\
\text { founded was } 2004 \text { (Ni Switch } \\
\text { Executive, 2021). }\end{array}$ & $\begin{array}{l}\text { The founding year of the } \\
\text { proposed software was } \\
1996 \text { (OpUtils, 2020). }\end{array}$ \\
\hline $\begin{array}{l}\text { COUNTRIES } \\
\text { IMPLEMENTED }\end{array}$ & $\begin{array}{c}\text { United States, Canada } \\
\text { (Cisco Open SDN Controller, } \\
\text { 2014). }\end{array}$ & $\begin{array}{l}\text { United States, Spain, and } \\
\text { Latin America (Ni Switch } \\
\text { Executive, 2021). }\end{array}$ & $\begin{array}{l}\text { United States, Japan, Spain, } \\
\text { Germany, China (OpUtils, } \\
\text { 2020). }\end{array}$ \\
\hline VERSIONS & $\begin{array}{c}\text { v.1.2, v.1.2.1, v.1.1, v.1.0 } \\
\text { (Cisco Open SDN Controller, } \\
\text { 2014). }\end{array}$ & $\begin{array}{c}\text { v.3.5, v.3.0, v. } 2.0 \text { (Ni Switch } \\
\text { Executive, } 2021)\end{array}$ & $\begin{array}{l}\text { v.12.3, v.11.0, v.6.0, v.5.0 } \\
\text { (OpUtils, 2020). }\end{array}$ \\
\hline $\begin{array}{l}\text { TYPE OF } \\
\text { SOFTWARE }\end{array}$ & $\begin{array}{c}\text { Licensed Paid Software } \\
\text { (Cisco Open SDN Controller, } \\
\text { 2014). }\end{array}$ & $\begin{array}{l}\text { Licensed Paid Software (Ni } \\
\text { Switch Executive, 2021). }\end{array}$ & $\begin{array}{l}\text { Free Software/ Licensed } \\
\text { Paid Software (OpUtils, } \\
\text { 2020). }\end{array}$ \\
\hline $\begin{array}{l}\text { OPERATING } \\
\text { SYSTEM }\end{array}$ & $\begin{array}{l}\text { Linux (Cisco Open SDN } \\
\text { Controller, 2014). }\end{array}$ & $\begin{array}{l}\text { Windows (Ni Switch } \\
\text { Executive, 2021). }\end{array}$ & $\begin{array}{l}\text { Windows, Linux (OpUtils, } \\
\text { 2020). }\end{array}$ \\
\hline $\begin{array}{l}\text { PROGRAMMING } \\
\text { LANGUAGE }\end{array}$ & $\begin{array}{l}\text { Java (Cisco Open SDN } \\
\text { Controller, 2014). }\end{array}$ & $\begin{array}{c}\text { C\#, VB .NET, C/C++ y } \\
\text { ActiveX, Python (Ni Switch } \\
\text { Executive, 2021). }\end{array}$ & Java (OpUtils, 2020). \\
\hline CHARACTERISTICS & $\begin{array}{l}\text { The software is distributed, } \\
\text { enforced, validated, and } \\
\text { supported by its commercial } \\
\text { distribution. On the other } \\
\text { hand, high availability } \\
\text { and quality in clustering is } \\
\text { maintained. In addition, ease } \\
\text { of service is maintained for } \\
\text { monitoring, metrics collection } \\
\text { and risk management (Cisco } \\
\text { Open SDN Controller, 2014). }\end{array}$ & $\begin{array}{l}\text { The integration of several } \\
\text { modules can be automated. } \\
\text { Likewise, it is identified in } \\
\text { the configuration of the } \\
\text { deployment of switches from } \\
\text { a file or network. Where the } \\
\text { configuration of software } \\
\text { modules and drivers is } \\
\text { guaranteed (Ni Switch } \\
\text { Executive, 2021). }\end{array}$ & $\begin{array}{l}\text { IP addresses are managed. } \\
\text { Ports are also managed. } \\
\text { In this way, the control } \\
\text { of unauthorized devices. } \\
\text { It is managed in the } \\
\text { Configuration Files (OpUtils, } \\
\text { 2020). }\end{array}$ \\
\hline TOOLS & $\begin{array}{l}\text { Allows you to manage Cisco } \\
\text { OpensFlow. Thus, it is } \\
\text { administered in Cisco PCEP. } \\
\text { It also allows to manage } \\
\text { Cisco BGPLS (Cisco Open } \\
\text { SDN Controller, 2014). }\end{array}$ & $\begin{array}{l}\text { LabVIEW, LabVIEW NXG, } \\
\text { LabWindows/CVI (Ni Switch } \\
\text { Executive, 2021). }\end{array}$ & $\begin{array}{c}\text { SNMP Tool, CISCO Tools, } \\
\text { Diagnostic Tools, Network } \\
\text { Monitoring Tools, IP Address } \\
\text { Monitoring Tools, Network } \\
\text { Tools (OpUtils, 2020). }\end{array}$ \\
\hline
\end{tabular}




\begin{tabular}{|c|c|c|c|}
\hline \multirow{2}{*}{ INDICATORS } & \multicolumn{3}{|c|}{ SOFTWARE } \\
\hline & OpenStack & Open vSwitch & OpenQRM \\
\hline BENEFITS & $\begin{array}{l}\text { Automate standards-based } \\
\text { network infrastructure. It } \\
\text { also allows optimizing the } \\
\text { acceleration in information } \\
\text { technology. (Cisco Open } \\
\text { SDN Controller, 2014). }\end{array}$ & $\begin{array}{l}\text { Manage network } \\
\text { performance on the } \\
\text { switch. In this way, it } \\
\text { allows to stimulate the } \\
\text { values of the network } \\
\text { domain. It also enables } \\
\text { logging and reporting of } \\
\text { performance test failures. } \\
\text { It also allows directing } \\
\text { switching operations. Where } \\
\text { calculations and data } \\
\text { manipulation are performed } \\
\text { (Ni Switch Executive, 2021). }\end{array}$ & $\begin{array}{l}\text { Monitor packet losses and } \\
\text { discards of errors that you } \\
\text { have in the network under } \\
\text { critical metrics. In such } \\
\text { a way, it visualizes the } \\
\text { services of the physical } \\
\text { servers. It also allows to } \\
\text { manage the WAN and VolP } \\
\text { network (OpUtils, 2020). }\end{array}$ \\
\hline $\begin{array}{l}\text { IMPLEMENTATION } \\
\text { COST RANGE }\end{array}$ & $\begin{array}{c}\text { Standard } \\
\$ 795.00-\$ 928.00 \\
\text { Professional } \\
\$ 1,031.00-\$ 5,995.00 \\
\text { Enterprise } \\
\$ 6,216.0-\$ 300,000.00 \text { (Cisco } \\
\text { Open SDN Controller, 2014). }\end{array}$ & $\begin{array}{c}\$ 1,690.00 \\
\text { (Ni Switch Executive, 2021). }\end{array}$ & $\begin{array}{r}\$ 195.00 \text { - \$2,995.00 } \\
\text { (Martínez et al., 2010). }\end{array}$ \\
\hline
\end{tabular}

Source: own elaboration.

The OpenStack software demonstrates better technological qualities based on the quality of service control for integrated storage management, allowing the automation of modules, port management, IP addresses, configuration files and drivers of the application software, where this result is similar to the study of Garcia when mentioning that the OpenStack software has future possibilities to adapt to new technological changes, achieve constant updates and the possibility of having a distributed IaaS private cloud (Nicolalde, 2021).

On the other hand, OpUtils software then there are different types of tools that have facilitated the user to have network security. Similarly, the OpUtils software is very feasible with its management processes, such as: diagnostics, network monitoring, IP address monitoring, port management and anomaly 
detection, this result is different from Ramos when describing the Open vSwitch software maintains a controlled configuration and an organized database scheme given by its tools: Ovs- vsctl, Ovs-ofctl and Ovs-testcontroller which are utilities and drivers to administer, configure, query and manage the ports of the switch interfaces. Next, the Open vSwtich software incorporates functionalities within the network based on the processes of the switches by the use of configurable flows, software compatibility and its high margin in its processing in sending software packages to hardware, this study is different from that of Martinez, Valencia and Osorio (2010) when performing an evaluation of analysis and management tools (Cacti and Nagios) for its ability to identify and analyze functionalities in the ports of the switches in the network, easy configuration, process optimization and meet the needs of the case based on the performance of the default software (Martínez et al., 2010).

Finally, the Open vSwitch open-source software shows to be a good function for medium-sized organizations for its ease of use, modification of the software itself and user domain, in addition to maintaining a phase of installation and management of resources mitigating problems such as ports and interfaces of the switches on the network, in this regard coincides with the work of Martinez, Valencia and Osorio (2010) mentioned that it is necessary to have monitoring tools for network devices to solve problems based on ICT resources, which is why they mention having licensed software to maintain high standards for users on the network and not being able to limit solutions to anomalies with a margin from \$195 to \$2,995 (Martínez et al., 2010).

\section{CONCLUSIONS}

The conclusions of the research were as follows: OpUtils is the most experienced licensed software in the market in technology platforms based on the evaluation of the performance of the software to manage switches being one of the national and international companies that had a great heyday for its low cost and quality service (OpUtils, 2020). On the other hand, Open vSwitch is the software that shows a high level of software updates that allow blocking errors in the source code and patches in poorly developed 
configurations and maintain security in the management of ports and interfaces for switches. This is due to the fact that the software is based on open-source code allowing to optimize its processes (Open vSwitch, 2020). Thus, OpUtils software is the best option because it can be adapted to the operating systems most commonly used in technological entities (Windows and Linux); since its distributions and dependencies are the easiest way to install and manipulate the software based on the management, administration and monitoring of the switches in the network (OpUtils, 2020).

Next, the OpenStack software shows a great difference compared to the switch software, since it shows technological peculiarities focused on the quality of service control, allowing to manage, automate and optimize port modules and controllers of the application software, adapting to the existing technological changes (OpenStack, 2020; Garcia, 2020). On the other hand, OpUtils is the software that has the most popular and applied options for medium-sized organizations because it is able to facilitate the user in keeping the network secure in the switches given in its management processes (diagnostics, network monitoring, port management and anomaly detection (OpUtils, 2020).

In addition, Open vSwtich software proved to be a good choice for SMEs because it incorporates security functionalities on switch ports in the network due to its simple configurable flow, software compatibility and high processing margin in sending software packages to hardware (OpenStack, 2020). In addition, Open vSwitch software is the only open-source brand suitable for small and medium-sized organizations due to its ease of use, proprietary software modification and user control. In addition, it maintains full resource management by mitigating problems on ports and switch interfaces in the network (Open vSwitch, 2020). Finally, it can maintain high standards for privileged users, real-time anomaly detention and stop the cause of the problem is necessary to employ a licensed software such as Cisco Open SDN Controller for its full functionalities (Cisco Open SDN Controller, 2014). 


\section{RECOMMENDATIONS}

The recommendations of this research are the following: this qualitative study can be continued in a quantitative way by assigning variables, numerical and statistical data to measure the selected and mentioned indicators. To carry out a classification study is a good option to obtain the evaluation software in the performance of switches and which one is the most suitable for specific sectors and network administrators. To develop the research work using the convergent mixed method to obtain qualitative and quantitative data and to compare the information in search of similarity and/or difference. It is recommended to conduct longitudinal studies to analyze and detail technological changes in the evaluation of switch software performance. Perform a classification research covering more than 6 switch management software to increase the alternatives for the selection of a complete software that meets the needs of the stakeholders. Finally increase the number of variables with the objective of taking the research to a more in-depth study to provide support to technical network administrators in the security of ports on switches.

\section{REFERENCES}

Gardona, J. (2019). Design of a theoretical and practical guide on software-defined networks (SDN) for the Santiago de Cali University (Thesis). https://repository.usc.edu.co/handle/20.500.12421/4158c

Gisco Open SDN Gontroller. (2014). Cisco Open SDN Controller. Cisco. https://www.cisco.com/c/en/ us/support/cloud-systems-management/open-sdn-controller/series.html?dtid=osscdc000283

Gujilema, D. (2011). Proposed Solution to Insecure Access to Resources in Corporate LAN Networks Using Free Software Network Access Control Applications (Thesis). Chimborazo Polytechnic Higher School, 114 pp. http://dspace.espoch.edu.ec/bitstream/123456789/983/1/38T00274\%20UDGTFIYE.pdf 
Garcia, D. (2020). OpenStack: An Infrastructure as a Service alternative for higher education institutions. Information Technology Research fournal: RITI, 8(15). 1-17. https://dialnet.unirioja.es/ servlet/articulo? codigo $=7237680$

Gómez, G. (2013). Processing of large volumes of data in CLOUD COMPUTING environments using HADOOP MAPREDUCE (Thesis). University of Almería. http://repositorio.ual.es/bitstream/ handle/10835/2189/TRABAJOCarlos\%20Gomez\%20Martinez.pdf?sequence=1

Luna, A. (2019). Switch port security. Networks and telecommunications. http://ri.utn.edu.mx/handle/ 123456 $789 / 114$ ? show $=$ full\&locale-attribute $=$ en

Martínez, F., Valencia, J., \& Osorio, O. (2010). Using Open Source Tools to Manage Network Devices: An Automotive Security Components Company Case. In XIV International Congress of the Academy of Administrative Sciences A.C. (ACACIA). 1-30. http://acacia.org.mx/busqueda/pdf/ C11P14C.pdf

Melwani, K. (2018). Simulation of a Commercial switch on Open vSwitch. University of the lagoon. https:// riull.ull.es/xmlui/bitstream/handle/915/8630/Simulacion\%20de\%20un\%20switch\%20 comercial $\% 20$ sobre $\% 200$ pen $\% 20$ vSwitch $\% 20$.pdf? sequence $=1$

Morillo, D. (2014). Implementation of a prototype of a software-defined network (SDN) using a softwarebased solution (Thesis). National Polytechnic School, 196 pp. https://bibdigital.epn.edu.ec/ bitstream/15000/7360/1/CD-5509.pdf

NI Switch Executive. (2021). Small size, big performance. https://www.ni.com/

Nicolalde, W. (2021). Design of an intrusion detection system (IDS), based on neural networks for a softwaredefined network (SDN) in the faculty of engineering in applied sciences (fica) of the northern technical university (Thesis). Technical University of the North, 199 pp. http://repositorio.utn.edu.ec/ bitstream/123456789/10907/2/04\%20RED\%20254\%20TRABAJO\%20GRADO.pdf 
Open vSwitch. (2020). Production quality, multilayer open virtual switch. http:/ /www.openvswitch.org/

OpenQRM. (2021). Professional open source data center and cloud management. https://openqrm-enterprise. $\mathrm{com} /$

OpenStack. (2020). The most widely deployed open source cloud software in the world. https://www.openstack. org/

OpUtils. (2020). OpUtils - Product overview. ManageEngine. https://www.manageengine.com/products/ oputils/oputils.html

Pfaff, B., Pettit, J., Koponen, T., Jackson, E., Zhou, A., Rajahalme, J., Gross, J., Wang, A., Stringer, J., \& Shelar, P. (2015). The Design and Implementation of Open vSwitch. In 12th USENIX Symposium on Networked Systems Design and Implementation (NSDI '15). 1-15. https://www. usenix.org/system/files/conference/nsdi15/nsdi15-paper-pfaff.pdf

Sánchez, M., Fernández, M., \& Díaz, J. (2021). Information gathering techniques and instruments: analysis and processing carried out by the qualitative researcher. UISRAEL Scientific fournal, 8(1), 107-121. https://doi.org/10.35290/rcui.v8n1.2021.400

Toapanta, B. (2006). Design and implementation of a basic Linux-based layer 3 switch prototype. Thesis (Title in Information and Computing Systems (ISIS)), Quito: Escuela Politécnica Nacional. 193 pp. https://bibdigital.epn.edu.ec/bitstream/15000/146/1/CD-0164.pdf

Valencia, G. (2013). Network map, contingency plan update, installed software control, maintain tools from previous practices, support, documentation - telefonica de Pereira in 2012 (Thesis). Catholic University of Pereira. 40 pp. https://repositorio.ucp.edu.co/bitstream/10785/1365/1/CRISTIAN\%20CAMILO\%20 VALENGIA\%20CORREA.pdf 


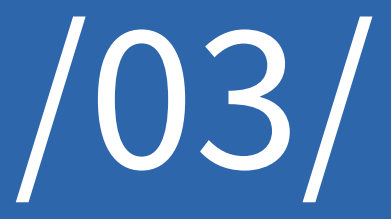




\section{CENTER OF TERRITORIAL DOMAINS AND THE NETWORK OF THE INCA ROAD - QHAPAQ ÑAN, IN THE PROVINCE OF TUMBES - PERU}

Ruben Martinez Cabrera

National University Federico Villarreal UNFV- INERN, (Peru).

E-mail: rmartinezc@unfv.edu.pe ORCID: https://orcid.org/0000-0002-4561-8627

Doris Esenarro

EUPG Escuela Universitaria de Posgrado - National University Federico Villarreal, (Peru).

E-mail: desenarro@unfv.edu.pe ORCID: https://orcid.org/0000-0002-7186-9614

Pedro Amaya

National University Federico Villarreal UNFV- INERN, (Peru). E-mail: pamaya@unfv.edu.pe ORCID: https://orcid.org/0000-0001-9123-0124

Violeta Vega Ventosilla

National University Federico Villarreal UNFV- INERN, (Peru). E-mail:vvega@unfv.edu.pe ORCID: https://orcid.org/0000-0002-7763-6993

Recepción: 10/07/2021 Aceptación: 22/10/2021 Publicación: 14/12/2021

Citación sugerida:

Cabrera R. M., Esenarro, D., Amaya, P., y Ventosilla, V. V. (2021). Center of territorial domains and the network of the inca road - Qhapaq Nan, in the province of Tumbes - Peru. 3C Tecnología. Glosas de innovación aplicadas a la pyme, 10(4), 51-87. https://doi.org/10.17993/3ctecno/2021.v10n4e40.51-87 


\section{ABSTRACT}

The present research aims to mathematically determine an archaeological site through spatial range-size analysis of limits and cultural boundaries. The methodology used collects information from archaeological sites in the province of Tumbes, identifies the urban centers of more significant extension, are spatially located using ArcGis software with ArcMap tool; with the spatial model, X-Tent also determined the territorial domains of attachment, in the analysis of the road network, generates the longitudinal profile and areas of influence through Thiessen polygons with which the domain areas are compared. With the values obtained, the territorial proportion has a constant $\mathrm{K}=1 / 555$; with these values, the domains of the archaeological sites of "Cabeza de Vaca" with an extension of 142,671.15 has an "El Guinea" with an area of 17,836.73 has been determined, located in the province of Tumbes district of Corrales and San Jacinto, separated by a distance of $60 \mathrm{~km}$, linear. The boundaries intersect territorially at the Huásimo archaeological site. It is concluded that the domain "Cabeza de Vaca" has an occupation of 80.62\% and "El Guineal" of $10.08 \%$ of the province of Tumbes; it was determined that in the intersection of both is located an archaeological site that was used as Tambo by the Incas, currently called Huásimo at an altitude of 787 meters above sea level.

\section{KEYWORDS}

Domains, Networks, Nodes, X-Tent, Thiessen Polygons. 


\section{INTRODUCTION}

The great Inca empire was interconnected by a network of roads called "Quapaq Nan," this network is distributed throughout Peru, including neighboring countries, the major network of the Inca road that goes from Cuzco - Cajamarca - Quito, has a detour in Piura (Poechos) to the west to intercept the Qda. Cuzco, continuing along this road you reach the archaeological site known as Guineal, continues through the dry forests of the protected natural area Cerros de Amotape, arriving at Rica Playa (CCPP), the road continued westward to reach the archaeological site of Cabeza de Vaca (Province) (Esenarro $e t$ al., 2021).

During Inca times, the Inca provinces were a critical territorial unit of imperial organization and administration (Vitry, 2017) These provinces were not mapped or physically restricted due to border limitations, and there is no clear information in ethnohistoric sources about their administrative and economic role. Regarding the Inca provinces, there is little discussion of their participation in the Tawantinsuyo and rarely an archaeological analysis of the provincial organization (Chacaltana et al., 2017).

Tumbes was peacefully annexed to the great Tahuantinsuyo Empire during the rule of the Inca Tupac Yupanqui, who, after subjugating Quito, decided to incorporate the "valleys of the plains" (Tumbes). The Incas introduced the customs of the Inca Empire, teaching to worship the Sun (Inti) and the Moon (Killa), so it was ordered to build a temple for the worship of the Sun, a house for the chosen virgins, a fortress where they were located as a garrison of war to people loyal to the Inka, a residence for the Inka "Huayna Capac" during his stay in the region (Hernandez, 2012). Likewise, many warehouses were built with supplies for the people who resided there or the warriors who passed through. All this represented the central city of Tumbes - Inka, which today is known as the monumental archaeological complex Cabeza de Vaca. 
Commercially Tumbes - Inka, and its city Cabeza de Vaca-, was a port of exchange, where it entered by sea from the north; the Spondylus heading south, by land by means of llama herds by "The way of the plains or Inca Trail." For this, it is presented as evidence over the entire scope of the project between Cabeza de Vaca and Rica Playa that, during the late horizon, "the Spondylus entered in rafts through ancient Tumbes, were transported by land and were carved in the tambos, also considering the findings of these shells along the coastal road between Poechos and Serran that confirm this transport" (Marcone, 2020).

The Guineal Center is located $8 \mathrm{~km}$ southwest of the hamlet of Capitan Hoyle and $64 \mathrm{~km}$ from Tumbes, in the lower middle course of the Quebrada Cusco, the current boundary between the Departments of Tumbes and Piura. It is located at 250 masl, UTM coordinates 9543363 N and 551195 E. 


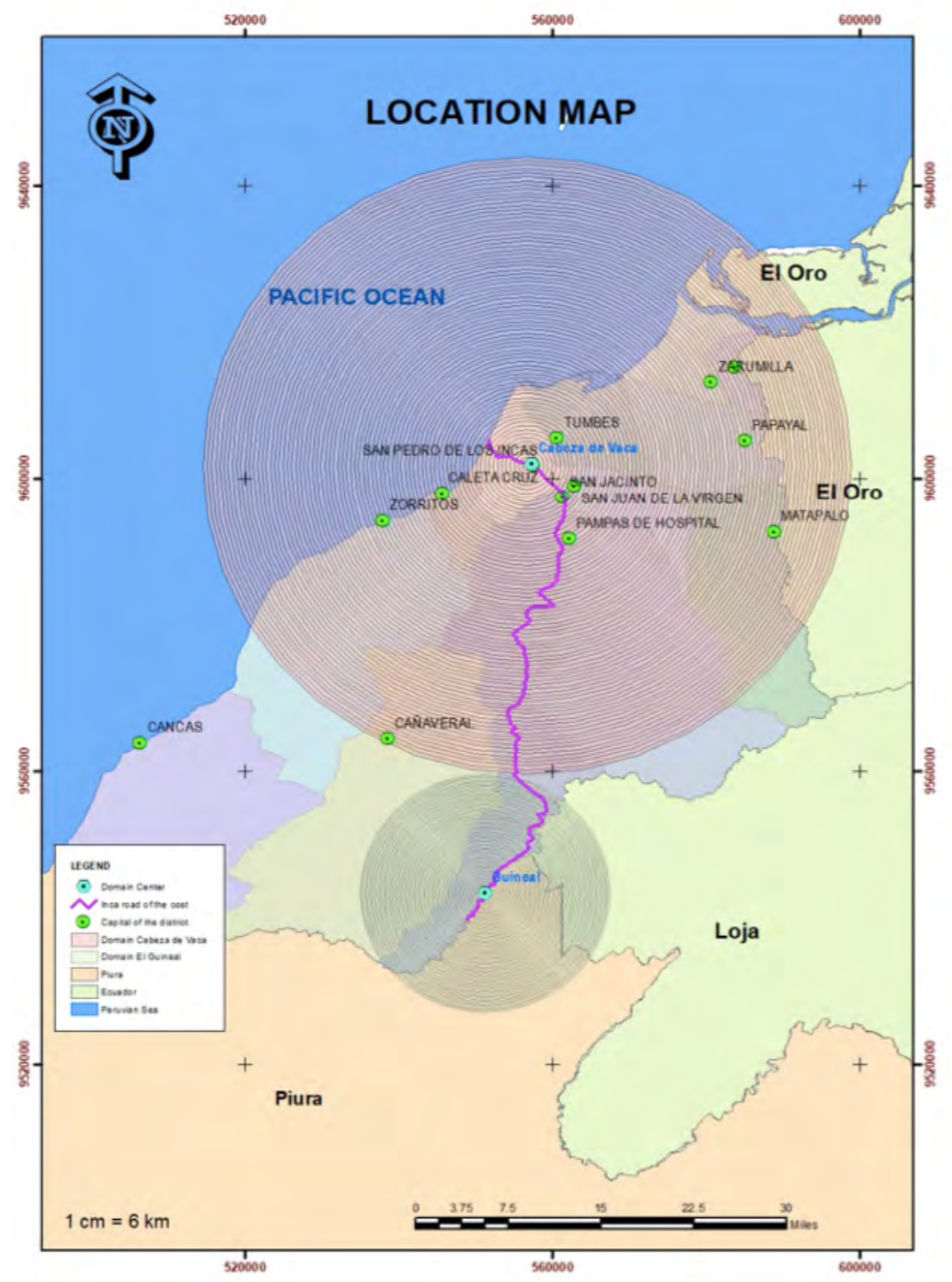

Figure 1. Location Map.

Source: own elaboration. 


\section{The Inca Road}

Approximately five hundred years ago, when Europe was on its way to the American coasts, a vigorous process of development and integration was taking place in large part of the territory now occupied by the countries of the Andean region, which was the product of one of the greatest civilizations in the world, the Incas (Ministerio de la Cultura, 2013).

The Inca empire was the most crucial state in American history, and its creation would have been impossible without the road system that served transportation, communications, and administration. Elevated roads in the Andean region take on particular importance when compared to those of other societies. For this reason, early Europeans repeatedly praised Inca roads and found them superior to those of 16th century Europe (Sternfeld, 2007).

Many of the Inca roads are still intact, and some are in excellent condition. Using this road system, diverse activities were developed, which are indispensable in the development and functioning of a state. It was as if a single, enormous entity replaced our air, rail, and land networks, our postal and telephone system, as well as part of the national administrative system (Vilchez, 2013).

The Inca roads represented the power of a state around not only its space articulated by 23,000 km of roads but also the link between the natural and the supernatural, within a cultural universe that stretched from the north of Argentina and Chile to the plains of Venezuela.

For the Incas, the Capac Ñan or Inca Nan (Great Road or Inca Trail) was a complex administrative, transportation, and communications system and a means of delimiting the four primary divisions of the Empire. The main road led from the capital, Cusco, to each of the four suyos into which the Inca Empire was divided (Antisuyo, Contisuyo, Chinchaisuyo, and Collasuyo). The Inca roads also described the geography of the state and the control it exercised over the peoples that formed it (Moralejo, 2012). For the conquered peoples throughout the empire, the roads constituted an omnipresent symbol of the power and authority of the Inca state. There must probably have been very few individuals subject to 
the empire who had not at some time seen an Inca Trail. The vassal populations also understood that the roads were built and maintained with their labor; as part of their obligations to the dominant state, the Inca Empire had to be seen as a symbol of the power and authority of the Inca state.

The Inca road system had two major longitudinal roads, one from the coast, which linked the current Chilean territory with Tumbes; the other, the backbone of the kingdom, linked Cusco with Quito, crossing the entire highlands; in many sections, it was paved and equipped with drains, bridges, retaining and defense walls, embankments and steps. The Great Road or Capac Nan of the Sierra was up to 16 $\mathrm{m}$ wide in some places. Some passes had a double roadway, one paved and wide and the other narrow and solid; through one passed the Inca and his court and through the other the supplies and helpers. On the southern coast of Peru, in the Waca ravine, there is a transversal road that carried fresh fish from the sea to the imperial capital of Cusco.

The Chinchaisuyo road was the most important of all. Its construction under the government of Tupac Yupanqui was the most significant state work of the imperial phase of the Quechua Cusco. When the territory of the Cañaris and the humid mountain ranges of the north were incorporated, the Incas weaved their network of roads according to the social system, and thanks to this way of organizing themselves, they developed an admirable road technology, which knew how to take advantage of previous traces and left, paradoxically, a precious inheritance to their European conquerors (Matos, 2017).

At its northern end, from Cajamarca, the Capac Nan took the Ecuadorian province of Loja to Tomebamba (now Cuenca). In Loja, the road passed through the Mariviña and Bola tambo. In Cuenca, a place of admirable roads, the great tambos were Tambo Blanco, Tomebamba itself, Paredones and Ingapirca, in the area called Hatun Cañar.

The transformation of the social organization accompanied the Inca entrance to the current Ecuadorian territory; the organization of work was made according to the Inca rotation systems to supply goods and services to the state structures (especially roads and tambos) (Pino, 2016). That is why this road appeared 
due to the last conquests, in the highest phase of Inca development, and its construction is of excellent quality.

In Inca times, the journeys were measured so that at the end of a trip (more or less every $30 \mathrm{~km}$ ), there was a large inn or Tambo. The Tambos Reales were equipped with authentic palaces with deposits for food, called colcas, meeting spaces and rooms for permanent service personnel. In addition, there were also post-like way points, the chasquiwasis, used by travelers and couriers (chasquis) (Smith, 2017).

\section{METHODOLOGY}

\subsection{THE INCA DOMAIN}

His political-social organization responds to the needs of a population, considering the potentials that the soil, air, and water give us; in this sense, urban growth was fixed since Inca times in good soil (agricultural) and water sources. In addition to the connectivity provided by a good road, the analysis of the streets should be carried out with the integration of multiple layers of information that include the review of data from archaeology, history, toponymy, ethnography (oral tradition), photographic and cartographic documentation, whether historical or recent, as well as other sources related to these that allow us to recognize the characteristics of the object of study: in our case, the Inca road network (Verhagen, 2018).

In the archaeological sites of the province of Tumbes, 99 vestiges were identified among mounds, enclosures, headwalls, tambos, canals, roads, among others, of which 25 are recognized as sites that housed population (Diaz, 2013).

A historical identification of these sites is made to determine the centers that had a more significant extension or larger structures over the other archaeological sites; in this sense, the El Guineal Center is identified, which has an attachment of 0.45 has and Cabeza de Vaca with 2.5 has; the constant (k) is 
calculated, placing the smaller area over the larger one, obtaining the value of $\mathrm{k}=1 / \mathrm{x}$ where $\mathrm{x}$ is the value of small size over a large area.

$\mathrm{I}=\mathrm{f}(\mathrm{C})=\mathrm{k} * \mathrm{~d} \quad \mathrm{X}$-Tent Model

I = Measure of Potential Political Influence of the Population Center

$\mathrm{f}(\mathrm{C})=$ Domain Center (size of infrastructure)

$\mathrm{k}=$ Constant (proportional size of the comparison of the structures of the centers)

$\mathrm{d}=$ Distance from the radius

Obtained the values we accept that our constant is $\mathrm{K}=1 / 5.55$ this value we multiply it by 100 getting a deal of $100 \%$ for Guinea and $555.55 \%$ for Cabeza de Vaca, with these values the domains are determined through the Arc Gis program. 


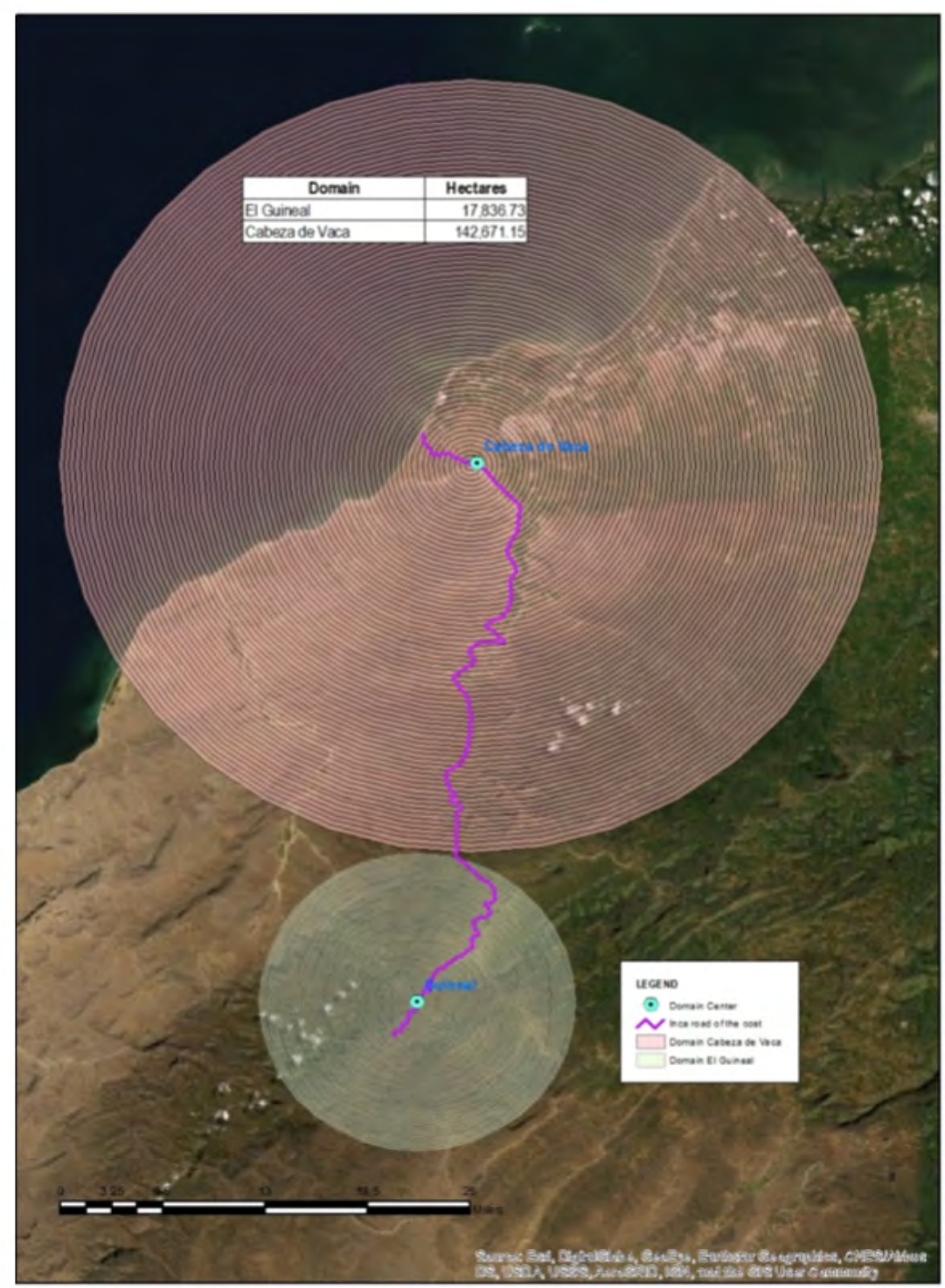

Figure 2. Territorial Domain of Cabeza de Vaca and El Guineal.

Source: own elaboration. 


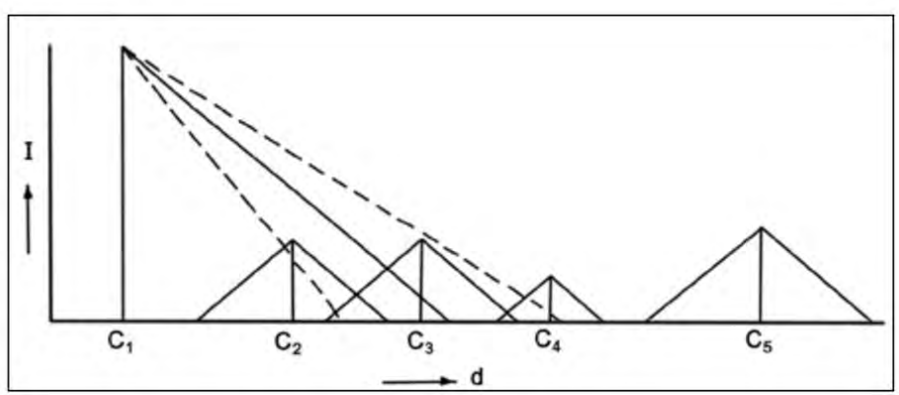

Figure 3. The X-Tent model.

\section{Source: own elaboration.}

Figure 3 presents the domain influence between the centers named C1, C2, C5, with a distance separating them (d); the size of each center is represented by a vertical line (I), The domain radius of each is given by the intersection of the continuous oblique line, which corresponds according to the size and growth constant. The dashed lines indicate the variation effect. In the figure, it is seen that C2 and C3 is influenced by C1, while part of C4 is out of reach and C5 totally out of the influence of C1.

\subsection{CURRENT AND INCA ROAD NETWORK}

The road network analysis is focused on identifying the connection of these with the various current and Inca population centers. To do this, using the geographic information system tool, we will spatially identify the current roads and the position of the population centers from which we will obtain the areas of influence through Thiessen's polygons (Martinez, 2010).

To obtain the measures of centrality, I will base myself on the current map of the Inca Road Network of the study area (Figure 2-3), dividing this network into sections defined by nodes and the connections between them; each identified Inca center corresponds to a node (point or vertex). Each unit is defined by two nodes located at the ends and the Inca Trail that links them. 
The Thiessen polygons (interpolation method, based on the Euclidean distance) are constructed from nodes (population centers) and networks (straight lines that join the nodes), with the nodes unions, are generated forming triangles and finding the point of the circumcenter from this point the perpendicular bisectors are traced to each segment, the intersections of these perpendicular bisectors determine a series of polygons of two-dimensional form (Peña et al., 2019).

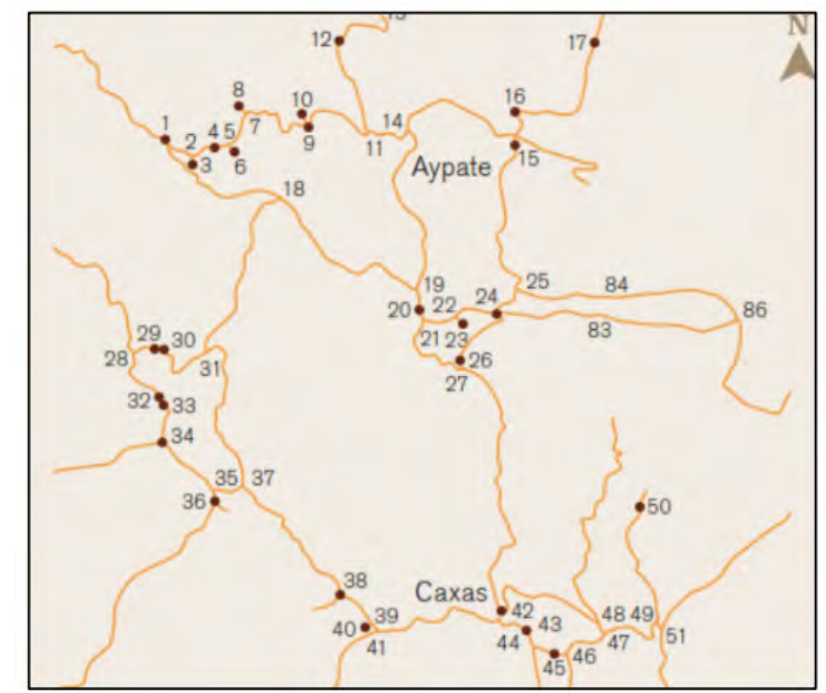

Figure 4. Inca roads in the highlands of Piura and associated sites.

Source: own elaboration.

The Inca road was understood as a road network. This network served as the articulator of a hierarchical administrative system of sites, including administrative centers and tambos. At the end of the day, these were the imperial structures that allowed an adequate administration of the imperial area. The Inca Trail and Inca archaeology in general, allowing not only to change the scale of analysis and link the past with the present, but also to give meaning to heritage management by linking the trail with its territory and its people. Figure 4 shows the Inca road network that reached Tumbes (Bernabe, 2017). 


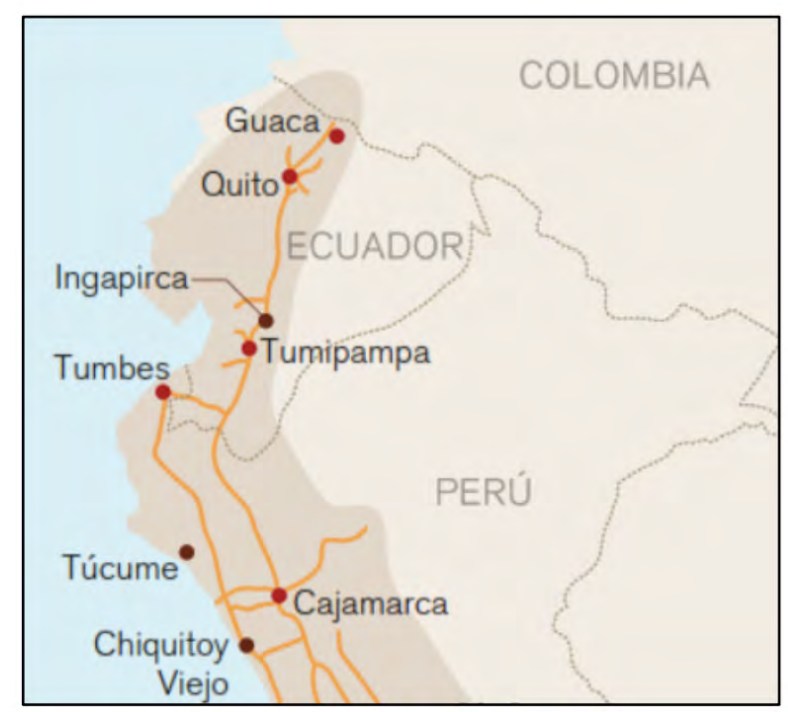

Figure 5. The Red Inca of Quapaq Ñan.

Source: own elaboration.

The great Inca Trail was an extraordinary achievement in design and engineering, unifying the Empire both physically and conceptually. Four main roads led from Cusco, the capital, to the four parts of the kingdom, while two longitudinal roads on a north-south axis formed the backbone of the entire territory. 


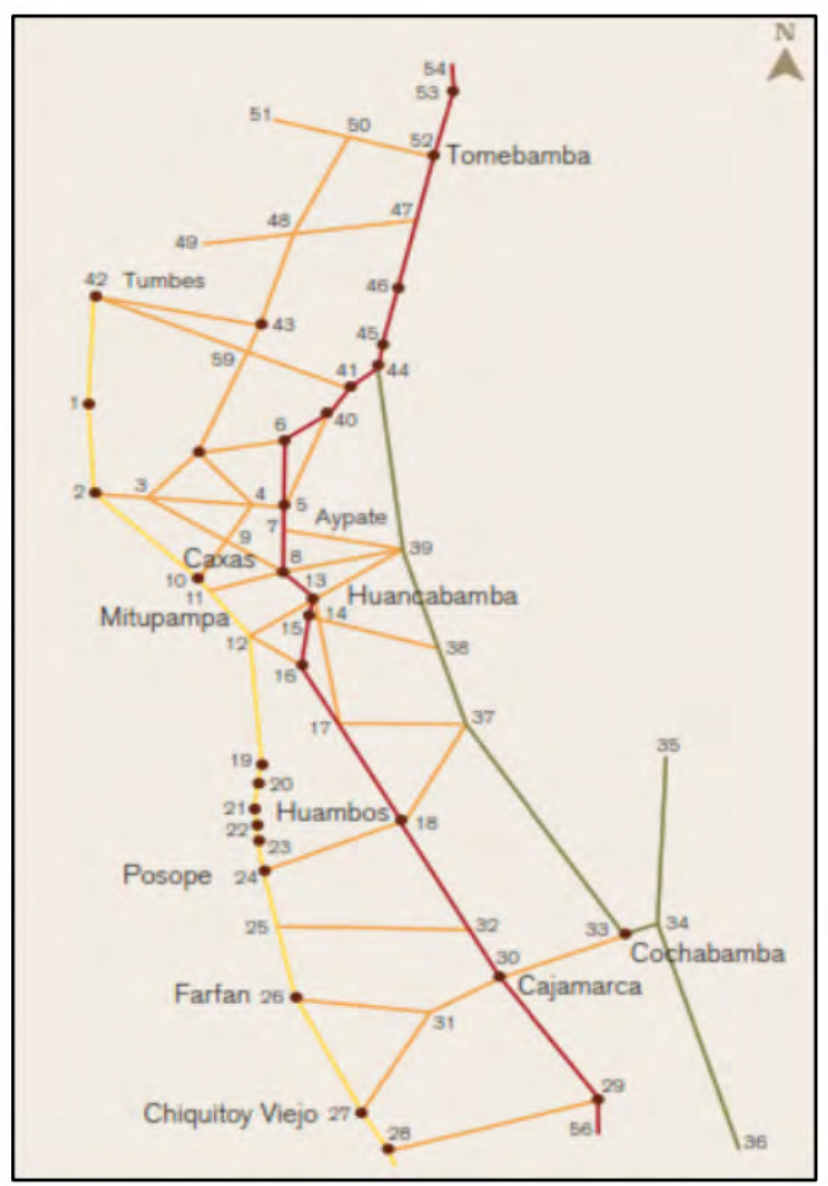

Figure 6. Typology of Inca roads and associated centers in southern Ecuador and northern Peru, considering the environmental characteristics.

\section{Source: own elaboration.}

Figure 6 shows the red line, a longitudinal road (Qhapaq Ñan) that associates the leading and most significant urban centers. In contrast, the Inca road of study in this research is a transverse road (orange color) but transcendental for the Inca commercial period and the area's locals (Bar, 2017). 


\section{RESULTS}

\subsection{CENTER OF DOMINION}

According to X-ten, the urban centers gave the Inca Domain Centers respect to their size, which considers that the dominance of the provincial centers is related to their size or the distance between these centers.

\subsection{CABEZA DE VACA CENTER}

Location, It is located on the left bank of the Tumbes River, Lower Valley. In the current hamlet of Cabeza de Vaca, district of Corrales, province, and department of Tumbes. It rises above 23 meters above sea level. With UTM Coordinates of $9602000 \mathrm{~N}$ and 557300 E., It is bordered on the north by the Pan-American Highway, on the east by the town of Corrales, on the west by La Garita hill, and the south by Loma del Viento.

It is accessed from Tumbes, $5 \mathrm{~km}$ from the Pan-American Highway north to the Corrales intersection. Take the Via de Evitamiento for 500 meters to the Cabeza de Vaca intersection and continue along a dirt road to the Cabeza de Vaca Sur hamlet. It is located at the junction of the hilly area with the plain; the site is bisected by the current irrigation canal and the Pan-American Highway North.

Type of Site: It is a Monumental Complex (Ceremonial Administrative Center), which currently occupies a space of approximately 100 hectares and consists of a series of stone and adobe structures, from which sectors are defined with functional and hierarchical differences (Administrative - religious - productive), such as:

The Huaca del Sol: It is the monumental structure of greater volumetric not only within the Archaeological Complex of Cabeza de Vaca but in the Valley of Tumbes; it is a truncated pyramid of adobe, erected in staggered levels, it is of rectangular plant oriented from southwest to northwest, it measures 250 meters long, 100 meters wide and 15 meters high. However, it appears to be a solid body inside. There 
are enclosures, passageways, patios, with walls 3 meters high, currently buried, whose heads are barely drawn on the ground as slight longitudinal elevations (González, 2017).

Malacological Workshop: Located in one of the hills located to the east of the Huaca del Sol. On the surface, there are a large number of malacological remains such as bivalves (Spondylus, Anadara, Ostrea) and shells (Strombus, Conus, Melongena) in different stages of work: complete, cut, totally or partially polished fragments; likewise, nodules, silhouettes of figures (preforms) and beautiful tiny figurines with anthropoid, Phyto and zoo morph representations have been recovered from this workshop; as well as lithic instruments that served to polish, cut, scrape and drill the raw material. Private collectors in the Department of Tumbes have valuable samples obtained in this workshop.

Huacas Menores: A group of mounds, whose floors do not exceed 40 x 30 meters and their height ranges between 3.8 and 1.5 meters, erected on the plain that extends to the north of the Huaca del Sol. These structures have been built with adobe and stone foundations, and their original size and shape have been destroyed by farmers using heavy machinery (Vilchez, 2015).

Irrigation Canal: It crossed the archaeological zone from east to west. Its line has disappeared, although versions indicate that the modern canal that runs parallel to the west side of the Huaca del Sol is the same line of the pre-Hispanic channel.

Associated Material and Cultural Filiation: Surface concentrations of cultural material are observed, both ceramic fragments of local style, tallán, Chimú, and Inca; malacological remains, both carving debris and remains of food, in addition to bone remains and stone tools (Albeck, 2016).

State of Conservation: The site is in a deplorable state of conservation. Currently, the Monumental Archaeological Zone of Cabeza de Vaca is subject to systematic destruction, accelerated during the last few years due to natural factors but, above all, to human action. Population growth and the expansion of the agricultural frontier are currently the significant impacts, as the need to install services for the population settled on the ruins (water and sewage networks, electrification, access roads, street paving, 
land clearing, etc.) have a significant impact on the destruction of archaeological contexts and the deterioration of the movable and immovable property.

In recent months, the population, instigated by some politically motivated individuals, has been demanding the execution of public works, threatening the Regional Cultural Directorate of Tumbes if they are not granted the permits they are requesting (Alessandri, 2016).

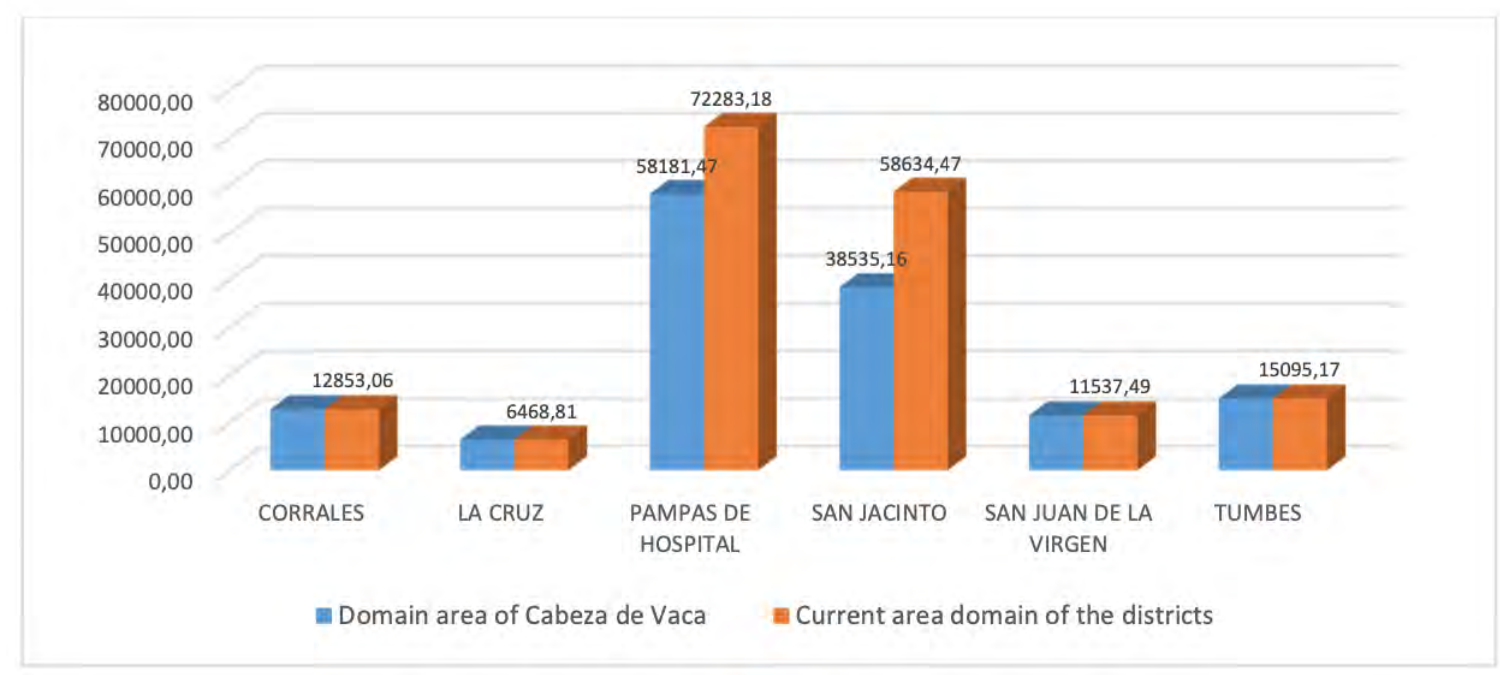

Figure 7. Areas of the Cabeza de Vaca Center domain and the current locations of the districts of the Province of Tumbes.

Source: own elaboration.

Figure 7 shows that the districts of Corrales, La Cruz, San Juan de la Virgen, and Tumbes were dominated, while the communities of Pampas de Hospital (80.5\%) and San Jacinto (65.7\%) were overwhelmed by the Cabeza de Vaca Center. 


\subsection{GUINEAL CENTER}

Politically it belongs to the Province of Tumbes, District of San Jacinto in the Department of Tumbes, and the Province of Sullana, District of Lancones, in the Department of Piura. It is located $8 \mathrm{~km}$ southwest of the town of Capitan Hoyle and $64 \mathrm{~km}$ from Tumbes, in the lower middle course of the Quebrada Cusco, the current boundary between the Departments of Tumbes and Piura. It is located at 250 masl, in UTM coordinates $9543363 \mathrm{~N}$ and $551195 \mathrm{E}$.

It is accessed from the city of Tumbes by following the Pan-American Highway North for 35 minutes to Bocapán. At this point, take the paved road to Casitas for 1 hour until the turnoff to Huásimo. After 3 hours, you arrive at the town of Capitán Hoyle, formerly Cazaderos, where you begin a 2-hour hike along the Cusco Creek upstream to the Guineal sector (Bernal, 2020).

In this section, the Cusco Creek has a regular surface, wide, sandy-stony bed. In contrast, the Guineal or El Mango Creek, which flows into the left bank, has an irregular surface, winding course, and a narrow, rocky bed with permanent water even in years of extreme drought. On the right bank, the surrounding hills are of medium elevation (sector 1); the lower part is an alluvial terrace with flat relief (sector 2), while the opposite side is higher with a moderate slope at the bottom (sectors 3 and 4). The vegetative cover consists of carob, pego pego, black huayacán, lion's ear, barbasco, charán, pasallo, polo polo, angolo, huápala, negrito, huarapo, sapote, hualtaco, palo santo, and shrubs such as aserrilla, frejolillo, and tongo (Diaz, 2013).

Type of Site: It is an archaeological complex composed of several stone structures, occupying approximately 14 hectares, on both banks of the Quebrada Cusco. To facilitate the study and description of the site, the site has been divided into four sectors. Each occupies a defined topographic location and shows peculiar characteristics in terms of the structures' density, shapes, and sizes. 
Table 1. Divided into four sectors.

\begin{tabular}{|c|c|}
\hline Sector 1 & $\begin{array}{l}\text { On the top of a hill, on the right side of the Quebrada Cuzco, there is a small structure of } 5 \times 4 \\
\text { meters, built with two staggered levels of one meter high, from where the environment is visually } \\
\text { dominated, on both sides of the slope there are retaining walls of rustic manufacture. }\end{array}$ \\
\hline Sector 2 & $\begin{array}{l}\text { At the foot of the hill mentioned above, a set of rectangular structures with a series of internal } \\
\text { divisions associated with a stepped design on a relatively flat relief. The slope towards Cuzco } \\
\text { Creek has been protected with retaining walls. }\end{array}$ \\
\hline Sector 3 & $\begin{array}{l}\text { It is the sector of greater hierarchy; it is a truncated Pyramid, achieved with three staggered levels; } \\
\text { it is approximately } 100 \text { meters long, } 45 \text { meters wide, and } 6 \text { meters high. The upper part is flat and } \\
\text { is divided into three large rectangular rooms; the second and third rooms have smaller enclosures } \\
\text { in one of its corners and an oval-shaped mound inside these enclosures. There is a stairway in } \\
\text { the front of the pyramid that connects with an epimural path on the lower level. Towards the sides } \\
\text { of the pyramid, there are attached in the lower part, expansive rooms of rectangular plan erected } \\
\text { with quite wide walls ( } 1.20 \text { meters) which are of double facing and have been built with stones } \\
\text { of significant size ( } 80 \times 90,78 \times 82) \text {. The front of the pyramid is located in front of the Quebrada } \\
\text { Cusco, while the Quebrada Guineal delimits the back and the right side. }\end{array}$ \\
\hline Sector 4 & $\begin{array}{l}\text { On the slope located on the left bank of the Quebrada Guineal, there is a set of three architectural } \\
\text { structures with internal divisions defined by walls of different dimensions, which are separated from } \\
\text { each other by runoffs of } 2 \text { to } 3 \text { meters wide, which have been channeled. Associated Material and } \\
\text { Cultural Filiation: The surface cultural material has always been very scarce; however, during the } \\
\text { last visit, a forging made by a local some weeks ago in sector } 4 \text { allowed finding abundant ceramic } \\
\text { fragments in the corner of one of the enclosures, which corresponds to the Inca and paleteado } \\
\text { style, confirming our initial appraisals on the place (20). }\end{array}$ \\
\hline
\end{tabular}

Source: own elaboration.

The state of Conservation. During the last few years, there has been an increase in visits, especially from high school students, which affects the conservation of the site because they spend one or more nights there: they use the stones from the walls to build fire pits and campsites, they walk on the top of the walls causing them to come loose, and they leave non-degradable garbage such as bags, cans, and bottles.

The nearest town is located 2 hours away on foot (Capitán Hoyle, Ex Cazaderos), but they have always felt great respect for the site, which explains why they have not depredated it; however, the progressive increase of visitors to the site has also awakened their curiosity, especially the younger ones, being the cause of the mentioned forging that allowed the identification of the ceramic material (Chacaltana $e t$ al., 2017). 


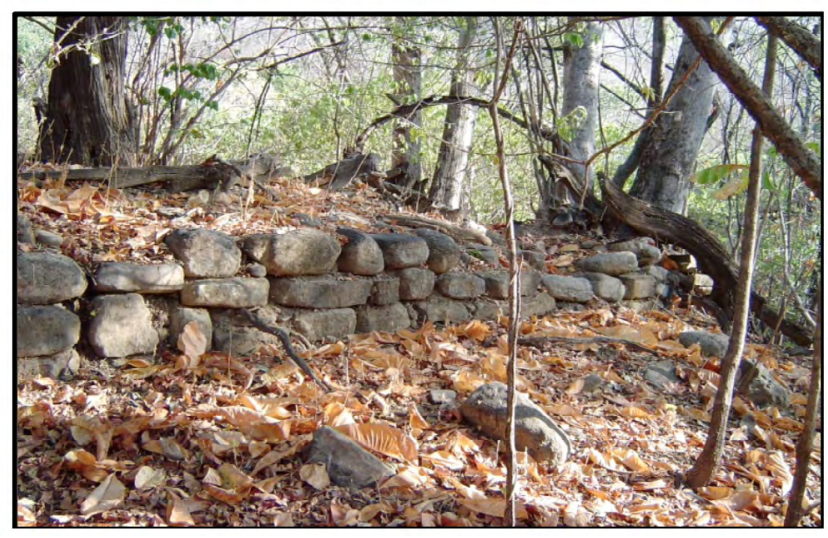

Figure 8. The Guineal Archaeological Center.

Source: own elaboration.

On the other hand, a destructive agent in Guineal has always been natural: the growth of trunks and roots of trees and bushes have managed to dislocate the masonry in varying degrees of intensity in the four sectors. In sector 4, it is observed that the descent of mud and stones that clogged the natural drains have affected the nearby architectural units, especially in the upper level.

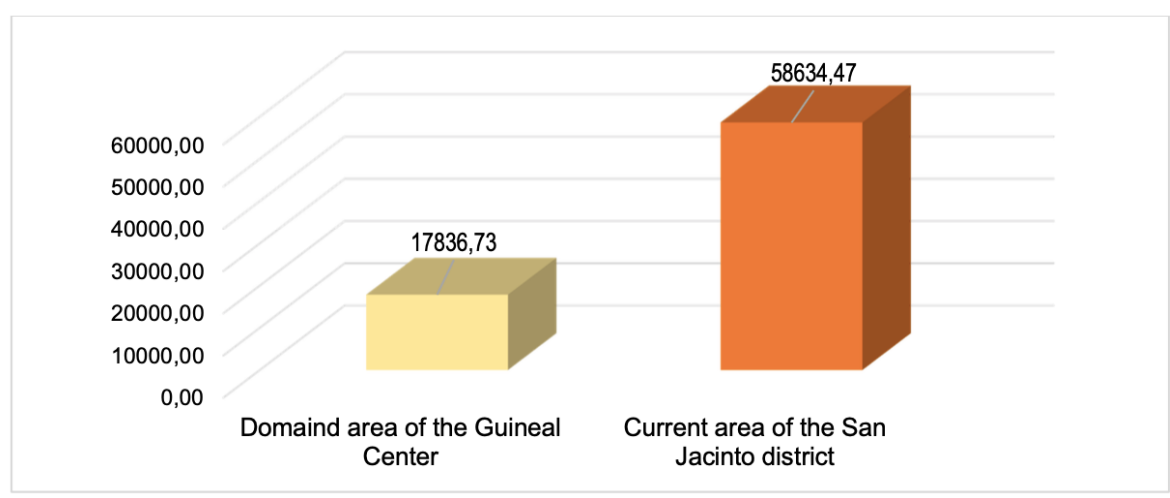

Figure 9. Areas of the domain of the Guinean Center and the current.

Source: own elaboration. 
Figure 9 shows that the only district influenced by the environment was the district of San Jacinto $(30.4 \%)$.

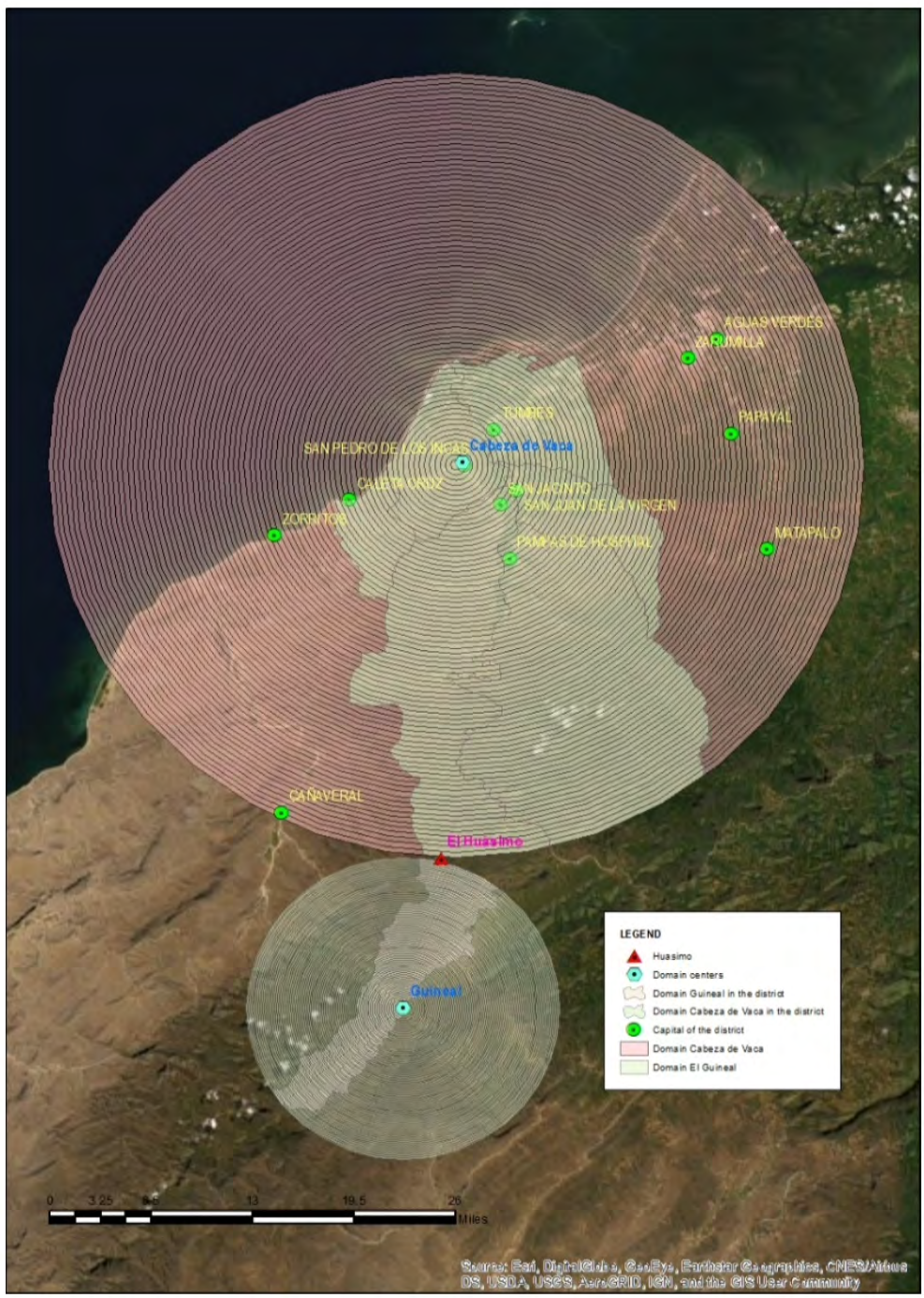

Figure 10. Cabeza de Vaca and Guineal Spatial Domain Center.

Source: own elaboration. 
The spatial domain of the Cabeza Vaca Center covers an area of 142,671.15 ha, while the Guinea Center amounts to $17,836.73$ ha; the sums of both areas represent $90.70 \%$ of the current province of the city of Tumbes.

The Centro de Cabeza de Vaca had a territorial extension of 100 ha; while Guineal was represented by 14 ha; the city of Cabeza de Vaca was 2.5 ha, while that of Guineal was 0.45 ha; with this information, the constant was obtained.

\section{$\mathrm{I}=\mathrm{f}(\mathrm{C})=\mathrm{k} * \mathrm{~d} \quad \mathrm{X}$-Tent Model}

$\mathrm{I}=$ Measure of the potential political influence of the population center.

$\mathrm{f}(\mathrm{C})=$ Domain Center (size of the infrastructure)

$\mathrm{k}=$ Constant (proportional size of the comparison of the structures of the centers)

$\mathrm{d}=$ Radius distance

Considering the data of both centers, it was obtained that the constant was $1 / 5.55$, which is applied progressively on both centers until its cohesion; this cohesion spatially coincides with the archaeological site called "Huasimo" according to the archaeological information this place had multipurpose (surveillance center, warehouse, rest) considered at that time as a Tambo (Tambo).

\subsection{THE ROAD NETWORK}

According to the spatial information of the Ministry of Transportation and Communications, the current road network in the province of Tumbes is represented by roads considering a classification into national, provincial, and district; in addition to the carriage roads, there are 301,309.10 meters of roads in the province. 


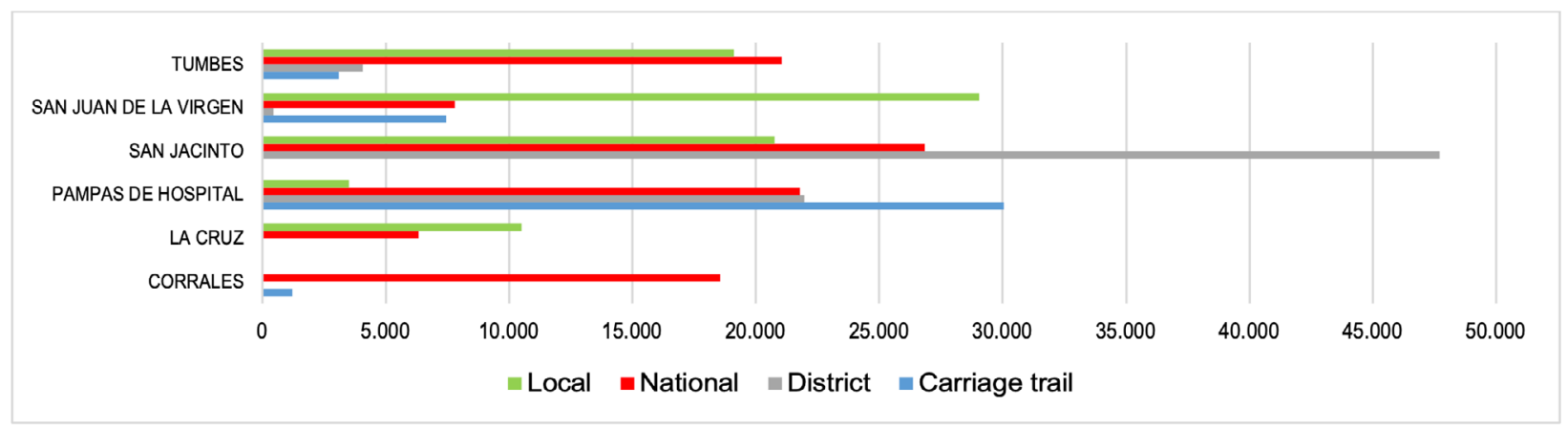

Figure 11. Current Road Network.

Source: own elaboration.

Figure 11 shows that national roads represent $33.97 \%$, while local roads represent $27.33 \%$, district roads represent $24.62 \%$, and dirt roads represent $13.88 \%$. The most significant number of roads is in the district of San Jacinto with 31.64\%, while the community of Pampas de Hospital represents 25.66\%, Tumbes with $15.71 \%$, San Juan de la Virgen with 14.85\%, Corrales with 6.56\%, and La Cruz with $5.58 \%$ (Moralejo, 2012).

The detailed classification of the local road network is shown in Figure 11, while Figure 12 shows the spatial distribution of the roads according to their classification. 


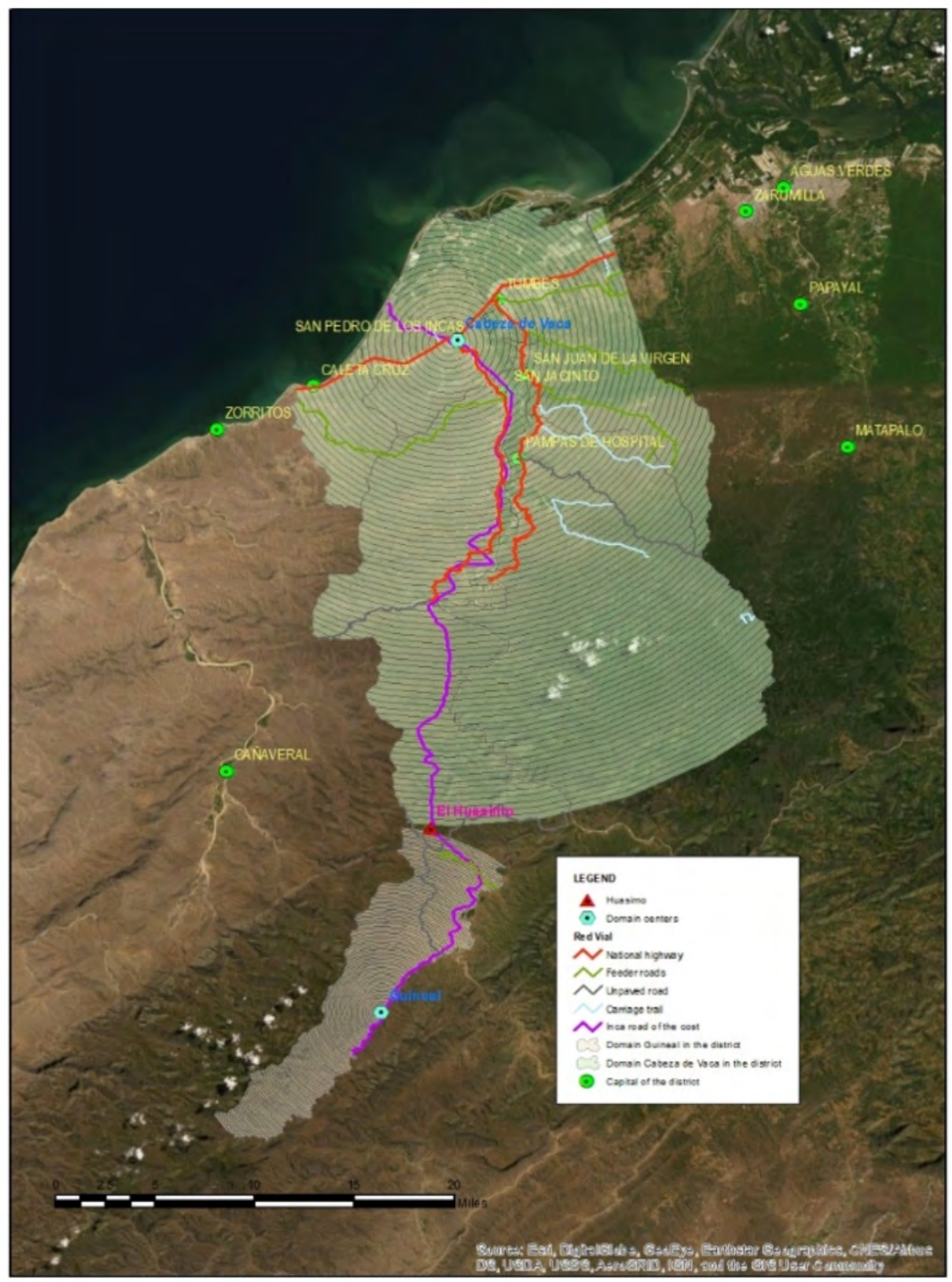

Figure 12. National Road Network and Inca Road Network in the Province of Tumbes.

Source: own elaboration.

The Inca road network enters the Tumbes Region in the southern area of the Cerros de Amotapepe

National Park following upstream along the Cuzco Creek near the hamlet called Captain Hoyle, which 
moves along the summits of the am tapes until reaching the Huasimo, an essential point because it is considered the limit of the domain and watershed, the road continued to get another critical population center called Rica Playa, from there the road moves parallel upstream left bank of the Tumbes River passing through San Jacinto and Corrales, in the latter, is located the Monumental Archaeological Zone Cabeza de Vaca, from there the road continued to reach near the Estero la Chepa, continuing to the seashore.

Table 2. Comparison of the National Road Network and the Coastal Inca Trail (meters)

\begin{tabular}{|c|c|c|c|}
\hline TYPE OF NETWORK & San Jacinto (Stretch in $\mathbf{~ m t )}$ & Corrales (Stretch in $\mathbf{m t})$ & Total (mt) \\
\hline $\begin{array}{c}\text { NATIONAL ROAD } \\
\text { NETWORK }\end{array}$ & 95325.76 & 18557.88 & 113883.65 \\
\hline INCA TRAIL & 79922.47 & 11837.83 & 91760.30 \\
\hline
\end{tabular}

Source: own elaboration.

Table 1 shows data on the Inca road network in the San Jacinto district, which covers $83.84 \%$ of the national road network, and in the Corrales district, which covers $63.79 \%$ of the national road network. In general terms, the Inca road network covers $80.57 \%$ of the national road network (no dirt roads or carriage roads were considered).

Figure 13 shows the coincidence of the limits of the domains of the two main archeological sites in the province of Tumbes and the Inca road, which according to its longitudinal profile, this intersection occurs at the highest altitude $(787$ m.a.s.l.), which is $29.7 \mathrm{~km}$ from the El Guineal Center (Chacaltana $e t$ al., 2017). 


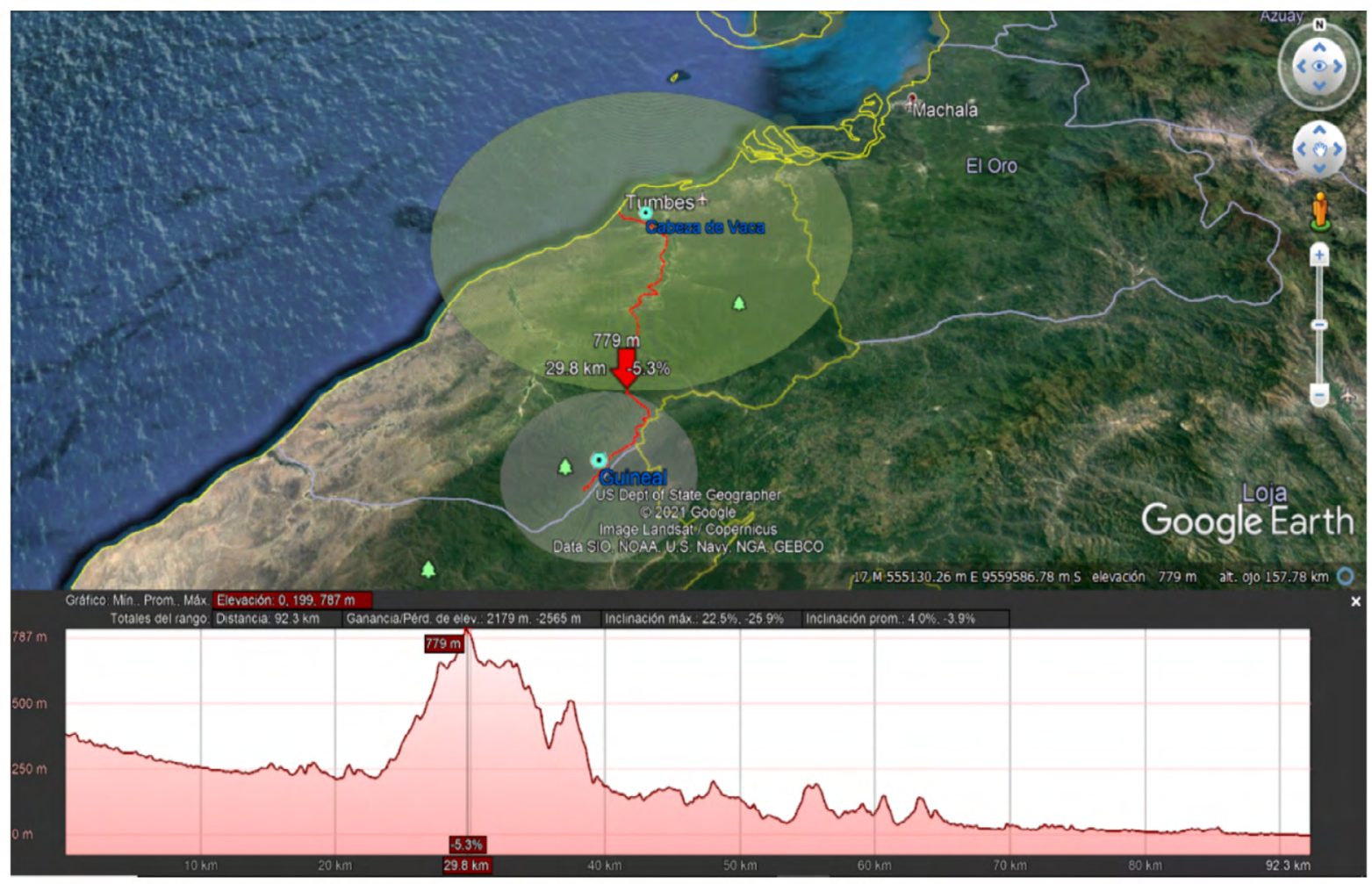

Figure 13. Profile of the Inca Trail and coincidence of Dominio de Cabeza de Vaca and El Guineal.

\section{Source: own elaboration.}

The maximum elevation of the Inca road profile is 787 meters above sea level. This coincides with the domains of the centers, which have been estimated from a constant due to the size of the structure of these archaeological sites. 

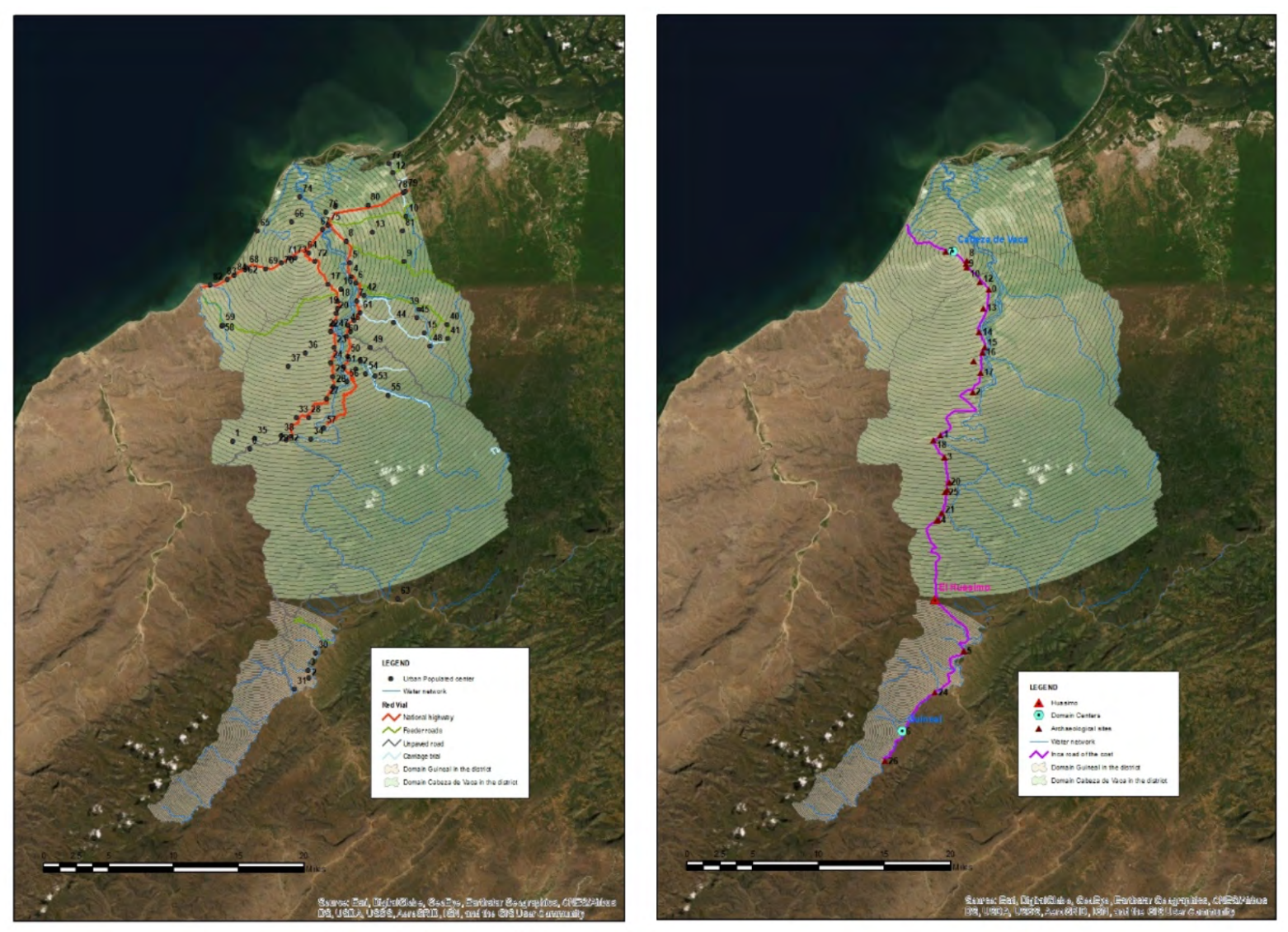

Figure 14. Current road network (right) and network in Inca times (left) in Cabeza de Vaca and El Guineal Center domains.

\section{Source: own elaboration.}

Figure 14 shows the road network of Tumbes and the Inca Trail and its connectivity with the population centers in current times and in Inca times. For the national grid, 85 population centers have been considered, and those near the road are 53. Table 2 shows the population centers located on the national highway or very close to it, with 33 hamlets, 07 towns, 02 annexes, one city, and one village, and 09 have no category. 
Of the villages, 33 are located on the national road, 02 in the district and one in the province, the towns with the category in the city 06 are located on the national highway, and one in the community, the villages with the type of annex are situated on the national road as well as the city and the town, of the 09 that do not have category four are located in the province, 03 in the national highway and 02 in the district.

Table 4. Inca Settlement Centers (Archaeological Remains) located along the Inca Trail.

\begin{tabular}{|c|c|c|c|c|c|}
\hline \multirow{2}{*}{$\begin{array}{l}\text { ARCHAEOLOGICAL } \\
\text { SITE NAME }\end{array}$} & \multirow{2}{*}{ DISTRICT } & \multirow{2}{*}{$\begin{array}{c}\text { TYPE OF } \\
\text { ARCHAEOLOGICAL SITE }\end{array}$} & \multicolumn{2}{|c|}{ UTM-Z17 COORDINATES } & \multirow{2}{*}{$\begin{array}{l}\text { ALTITUDE } \\
\text { M.A.S.L. }\end{array}$} \\
\hline & & & EAST & WEST & \\
\hline Miraflores & San Jacinto & Settlement (wall bases) & 561726 & 9597347 & 31 \\
\hline Higuerón & San Jacinto & Head of enclosure walls & 559762 & 9584810 & 78 \\
\hline Mal Paso & San Jacinto & Rectangular structure & 556293 & 9576845 & 157 \\
\hline Teniente Astete II & San Jacinto & Rectangular structure & 558660 & 9553150 & 232 \\
\hline Guineal & San Jacinto & Complex settlement & 551195 & 9543363 & 311 \\
\hline Huaca Cabeza de Vaca & Corrales & Complex settlement & 556450 & 9601977 & 23 \\
\hline EI Rodeo (Malval) & Corrales & Settlement (mound) & 559011 & 9600072 & 200 \\
\hline Santa Rosa (Plateros) & San Jacinto & Structure s/f & 561086 & 9595049 & 200 \\
\hline Vaquería & San Jacinto & Settlement & 561189 & 9590335 & 200 \\
\hline Casa Blanqueada & San Jacinto & Enclosure & 560693 & 9587196 & 200 \\
\hline
\end{tabular}




\begin{tabular}{|c|c|c|c|c|c|}
\hline El Tablazo & San Jacinto & Semicircular structure & 554944 & 9578925 & 200 \\
\hline Tierras Coloradas & San Jacinto & Rectangular Enclosure & 556941 & 9573749 & 200 \\
\hline Pellejitos & San Jacinto & Rectangular structure & 556637 & 9572893 & 123 \\
\hline Calabacitas I & San Jacinto & Rectangular structure & 555968 & 9570044 & 200 \\
\hline Ucumares I & San Jacinto & Rectangular structure & 555360 & 9569120 & 138 \\
\hline Teniente Astete I & San Jacinto & Rectangular enclosures & 558695 & 9553240 & 233 \\
\hline Capitán Hoyle & San Jacinto & Rectangular structure & 555142 & 9548120 & 261 \\
\hline Modroño & San Jacinto & Associated enclosures & 549031 & 9539737 & 357 \\
\hline
\end{tabular}

Source: own elaboration.

Eighteen archaeological remains show signs of population centers - Archaeological Inventory of the Qhapaq Ñan Project, 2009.

Figure 14 shows the areas of influence of the main Inca urban centers in the province of Tumbes, determined by the Thiessen polygons; on this influence, the current urban population centers are shown as a result: 


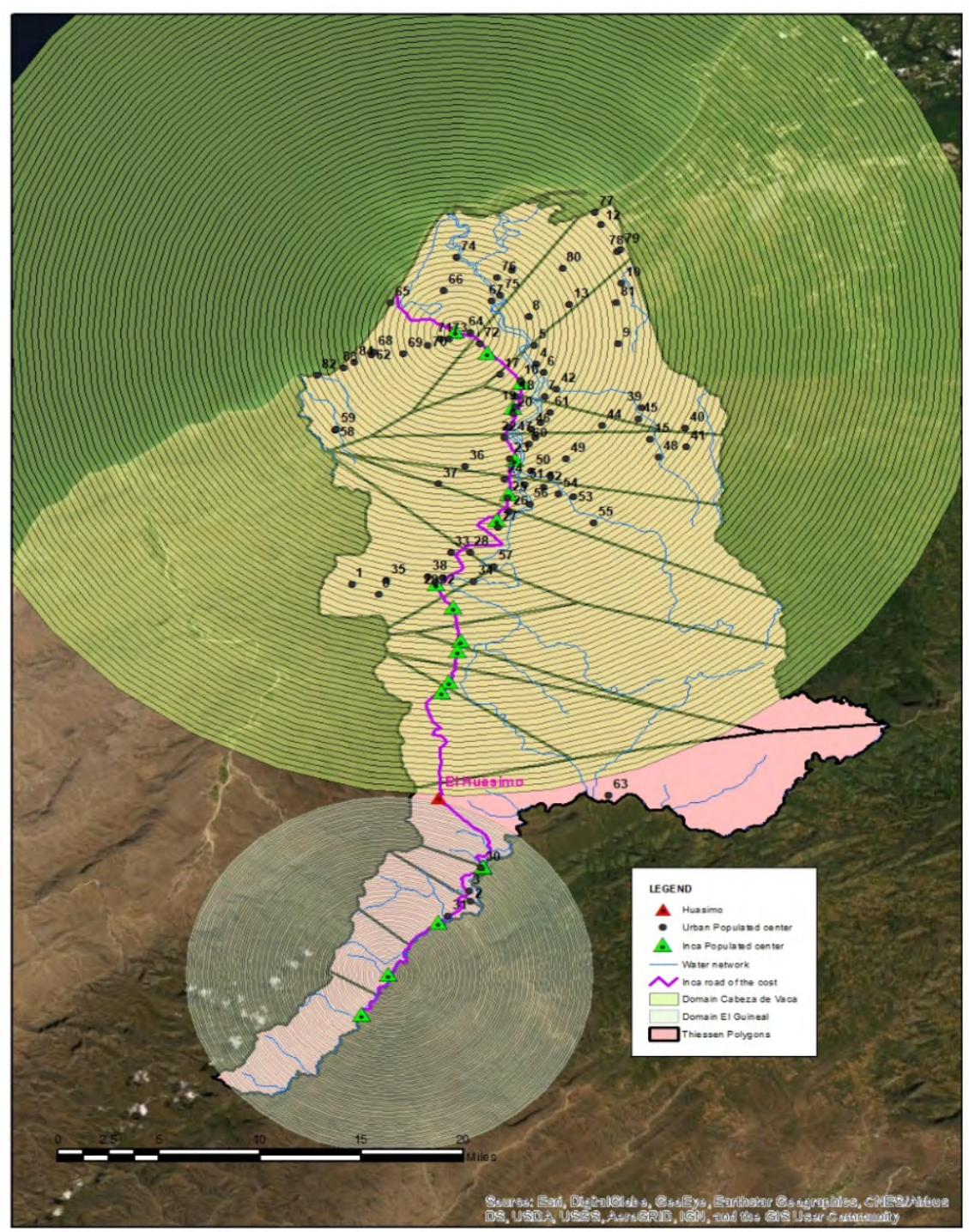

Figure 15. Areas of Influence (Thiessen polygons) of Inca Settlements and Urban Settlements (Current).

Source: own elaboration. 
The population center of Teniente Astete $\mathrm{I}$ is the largest in the province at $11.64 \%$. It currently has only one population center called El Zapayal, located in the Tumbes National Reserve. Huaca Cabeza de Vaca is the second-largest population center, representing $11.08 \%$. There are 19 urban population centers (see Table 3-2), and the third-largest in Tierras Coloradas, which currently has no population centers. This is because it is located in the Cerros de Amotape National Park.

\section{DISCUSSION}

The modeling methodology to determine the territorial domains of the Inca cities has not been expressed in detail since it is a hypothesis that determines the domain area through the size of the site. The X-Tent model shows the influence of a site based on the distance without knowing for sure how to handle this data.

In the investigation considering the information of the X-Tent model, it has been possible to develop the domain of two important Inca cities, Cabeza de Vaca and El Guinea based on the size of the structure that was the primary data for the calculation of the constant, applying distance according to this value through buffer the limits were determined, which coincide in an archaeological vestige called "Huasimo" that appear in Inca times was a Tambo, a place of multiple uses. It has not been done anywhere in Peru to apply this hypothesis that in the limits of domain of main Inca cities, there must be a place of vigil or control of the parts of the Inca cities.

The study and analysis of roads should be carried out with the integration of multiple layers of information that include the review of data from archaeology, history, toponymy, ethnography (oral tradition), photographic and cartographic documentation, whether historical or recent, as well as other sources related to these that allow us to recognize the characteristics of the object of study: in our case, the Inca road network. 
According to the author gives a methodological definition of the analysis of roads through the use of history and cartography, but does not present the location of nodes and networks as a practical case, in the research a current analysis of the situation of the roads (grids) and their coincidence with the population centers (nodes) is made, generating a comparison of the Inca cities and the Inca road network, including the influence of these through Thiessen's polygons, identifying the current population centers that are located in these areas of influence.

\section{CONCLUSIONS}

The X-Tent modeling gives us an approximation to the determination of the dominions of the Inca cities, based on a constant and a distance that starts from the center of each city through a buffer of proportion.

It was determined that the proportion of the Cabeza de Vaca Center with the El Guineal Center is 7 to 8 times greater in their domains and that their limits have as a meeting an Inca place, which according to current studies by archaeologists would be the Tambo called Huasimo.

The domain of Cabeza de Vaca covers an area of 142,671.15 hectares, while the El Guineal Center covers an area of $17,836.73$ hectares, the addition of both fields covers $90.70 \%$ of the current province of Tumbes.

The Inca road network has an extension of 91,760.30 meters, which represents $80.57 \%$ of the current road network travels over 18 Inca population centers, generating the same number of areas of influence determined by Thiessen's polygons, where 85 current population centers have been identified. Cabeza de Vaca has the most significant number of current population centers. El Guineal is located in the Cerros de Amotape National Park forests, a protected natural area with intangibility legislation, possibly because this fact has not allowed human settlements. 
Between the domains of Cabeza de Vaca and El Guineal is the site of Huasimo, which according to its longitudinal profile, is located at the highest point (787 m.a.s.l.) of the Inca Trail; this coincidence has been determined according to X-Tent calculations and the analysis of the Google Earth program.

\section{REFERENCES}

Albeck, M. E. (2016). Producción y lógica de la red vial incaica en el extremo septentrional del NOA. Arqueología, 22(1), 61-79. http://revistascientificas.filo.uba.ar/index.php/Arqueologia/article/ view/2465

Alessandri, L. (2016). Exploring territories: Bubble Model and Minimum Number of Contemporary Settlements: A case study from Etruria and Latium Vetus from the Early Bronze Age to the Early Iron Age. Origini, XXXVII, 173-197. https://research.rug.nl/en/publications/exploringterritories-bubble-model-and-minimum-number-of-contempo

Bar, A. (2017). Perspectivas del proyecto Qhapaq Ñan en torno al registro de la red vial inca: propuestas de su sectorización y nomenclatura. Boletín del Museo Chileno de Arte Precolombino, 22(2), 31-46. https://www.scielo.cl/scielo.php?script=sci_arttext\&pid=S0718-68942017000200031

Bernabé, J. (2017). La ruta inca a los Huaylas. estudio de la vialidad inca en la Pampa de LampasChoquerecuay, en el departamento de Ancash, Perú. Boletín del Museo Chileno de Arte Precolombino, 22(2), 47-63. https://www.scielo.cl/scielo.php?script=sci_arttext\&pid=S0718-68942017000200047

Bernal, A. (2020). Los límites septentrionales del imperio inca y el Qhapaq Ñan vistos desde la arqueología y la historiografía del Sur Andino de Colombia. Chungará (Arica), 52(3), 381-94. https://www.scielo.cl/scielo.php?script=sci_arttext\&pid=S0717-73562020000300381

Ghacaltana, S., Arkush, E., \& Marcone, G. (eds.). (2017). Nuevas tendencias en el estudio de los caminos (2nd ed.). Conferencia Internacional en el Ministerio de Cultura. Qhapaq Nan-Sede Nacional; 465 p. https://qhapaqnan.cultura.pe/sites/default/files/mi/archivo/Nuevas\%20tendencias.pdf 
Díaz, S. (2013). Qhapaq Ñan, Sistema Vial Andino: el desafío de su conservación en Chile en el marco de su nominación a la Lista del Patrimonio Mundial. Intervención (México DF), 4(8), 33-46. http:// www.scielo.org.mx/scielo.php?script=sci_arttext\&pid=S2007-249X2013000200005

Esenarro, D., Martinez, R., Miranda, M., Begazo, L., \& Segovia, E. (2021). Sustainable Construction of Ancasmarka and Its Functionality in the Pre-Inca and Inca Period, Calca - Cusco - Perú. Journal of Green Engineering (fGE), 11(2), 1244-1243. http://www.jgenng.com/volume11issue2.php

González, G. (2017). Arqueologia Vial del Qhapaq Nan en Sudamérica: análisis teórico, conceptos y definiciones. Boletín del Museo Chileno de Arte Precolombino, 22(1),15-34. https:/ /www.scielo.cl/scielo. php?script=sci_arttext\&pid=S0718-68942017000100015

Hernández, F. (2012). La Sucesión Entre Los Incas. Chungará (Arica), 44(4), 655-67. https://scielo. conicyt.cl/scielo.php? script=sci_abstract\&pid $=$ S07 17-73562012000400008\&lng=pt\&nrm $=$ iso

Marcone, G. (2020). Por las rutas del Qhapaq Nan: el rol de los caminos en la construcción de la historia y territorio peruano. Chungará (Arica), 52(3), 411-25. https://www.scielo.cl/scielo.php?script=sci_ arttext\&pid=S0717-73562020000300411\&lng=pt\&tlng=es

Martinez, G. (2010). Qhapaq Ñan: el camino inca y las transformaciones territoriales en los Andes Peruanos. Ería, (78-79), 21-38. https://doi.org/10.17811/er.0.2009.21-38

Matos, R. (2017). El gran camino Inka: construyendo un Imperio. Una exhibición sobre el Qhapaq Nan en el Museo Nacional del Indígena Americano, Smithsonian Institution. Boletín del Museo Chileno de Arte Precolombino, 22(2), 9-29. https://www.scielo.cl/scielo.php?script=sci_ arttext\&pid=S07 18-68942017000200009

Ministerio de Cultura. (2013). Cabeza de Vaca, investigaciones arqueológicas (Vol. 30). Biblioteca Nacional del Perú. 
Moralejo, R. A. (2012). El camino del Inka en el sector central de la provincia de Catamarca: actualización y perspectivas. Andes, 23(6), 19-36. https:/ /ri.conicet.gov.ar/handle/11336/79713

Pino, J.L. (2016). Qhapaq Ñan Wamanin: los lugares de libación como hitos de la memoria en cada paisaje sagrado de la ruta principal hacia el Chinchaysuyu. Diálogo Andino, (49), 167-80. https:// www.scielo.cl/scielo.php?script=sci_arttext\&pid=S0719-26812016000100018

Peña-Candia, L.Z., Baca-Zans, Y.R., \& Costa,J.F. (2019). Efecto de las actividades antrópicas en la red de caminos Inka, santuario histórico de Machupicchu, Cusco, Perú. Revista interamericana de ambiente y turismo, 15(1), 60-71. https://scielo.conicyt.cl/scielo.php?script=sci_abstract\&pid=S0718235X2019000100060\&lng=es\&nrm $=$ iso

Ramírez, S. E. (2008). Negociando el imperio: el Estado inca como culto*. Bulletin de l'Institut Français d'Études Andines, 37(1), 5-18. https://doi.org/10.4000/bifea.3201

Smith, M. E. (2017). Bounding Empires and Political/Military Networks Using Archaeological Data. OSF

Sternfeld, G. (2007). La organización laboral del Imperio Inca: las autoridades locales básicas. Iberoamericana Editorial Vervuert, S.L.

Verhagen, P. (2018). Spatial Analysis in Archaeology: Moving into New Territories. In: Siart, G., Forbriger, M., \& Bubenzer, O. (eds.), Digital Geoarchaeology. Natural Science in Archaeology. Springer, Cham. https://doi.org/10.1007/978-3-319-25316-9_2

Vilchez, G. (2015). El camino inca de la costa en el Parque Nacional Cerros de Amotape. Ministerio de Cultura.

Vilchez, G. (2013). El Taller de Spondylus de Cabeza de Vaca, Tumbes. Cuadernos del Qhapaq $\tilde{N} a n, \quad$ 1, 20. https://qhapaqnan.cultura.pe/sites/default/files/mi/archivo/Carolina \% 20 V\%C3\%ADlchez $\% 20-\% 20$ El $\% 20$ Taller $\% 20$ de $\% 20$ Spondylus $\% 20$ de $\% 20$ Cabeza $\% 20$ de $\% 20$ Vaca $\% 2 \mathrm{C} \% 20$ Tumbes.pdf 
Vitry, G. (2017). El rol del Qhapaq Nan y los Apus en la expansión del Tawantinsuyu. Boletín del Museo Chileno de Arte Precolombino, 22(1), 35-49. https://www.scielo.cl/scielo.php?script=sci_ abstract\&pid=S0718-68942017000100035\&lng=es\&nrm=iso 


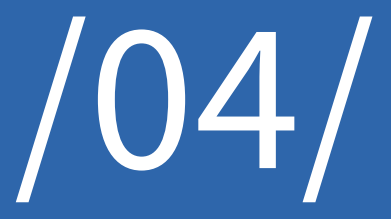




\title{
MODEL ELECTRIC CAR WITH WIRELESS CHARGING USING SOLAR ENERGY
}

\author{
Muhammad Osama Horani \\ Department of Mechatronics Engineering, SZABIST, Karachi, (Pakistan). \\ E-mail: m.osama.horani@gmail.com ORCID: https://orcid.org/0000-0002-0672-462X \\ Mariya Najeeb \\ Department of Mechatronics Engineering, SZABIST, Karachi, (Pakistan). \\ E-mail: mariynajeeb26@gmail.com ORCID: https://orcid.org/0000-0002-2317-7402 \\ Atif Saeed \\ Department of Mechatronics Engineering, SZABIST, Karachi, (Pakistan). \\ E-mail: m.atif@szabist.edu.pk ORCID: https://orcid.org/0000-0003-4369-2388
}

Recepción: 26/07/2021 Aceptación: 01/10/2021 Publicación: 14/12/2021

\section{Citación sugerida:}

Horani M. O., Najeeb, M., y Saeed, A. (2021). Model electric car with wireless charging using solar energy. 3C Tecnología. Glosas de innovación aplicadas a la pyme, 10(4), 89-101. https://doi.org/10.17993/3ctecno/2021. v10n4e40.89-101 


\section{ABSTRACT}

The current non-renewable energy-based transportation system is getting us places while simultaneously killing us. The global oil and gas markets are the most sizeable - 4677.45 billion-dollar industries - in the world in terms of revenue due to human dependency on fast transportation. In pre-industrial revolution times, the average rate of global temperature increase was 0.13-degrees Fahrenheit. The introduction of fossil fuel-based vehicles has more than doubled those numbers, thus resulting in accelerated global warming. Electrical vehicles have a few challenges of their own that we have discussed in this paper, finding solutions to them are based on Yoichi Hori's paper to make our model more energy efficient. Our model has been validated by researches done in the past, this paper combines the findings of formerly published papers to produce a working model of our current design with proof of concept. To reduce the carbon footprint of coal and fossil fuel-based electricity production, solar energy has been considered to charge the vehicle. It is not only an efficient choice, but it is also economical. It saves the consumer around $\$ 1778$ annually in fuel cost and $38.5 \mathrm{~g} / \mathrm{km}$ in carbon emissions. Using a wireless charging station solves a major UX design problem, making charging an effortless experience. This method is 88.05\% efficient at 31.5A. Supercapacitors have high power densities, therefore, being a good power source for the $\mathrm{EV}$ in theory, however, research shows that current supercapacitor technology is unable to perform as a standalone power source. Hence our model combines supercapacitors with conventional batteries to power the EV, additionally a break recovery system stores energy in the supercapacitor. This powers the car's acceleration. Our model priorities the use of materials that can be repurposed hence carbon-based electrodes are used - Graphene is a potential choice as it consists of high energy cycles.

\section{KEYWORDS}

Electric vehicles, Supercapacitors, Wireless power transfer, Solar energy, Sustainability, Power density, Climate change, Global warming, Resource management, Renewable energy. 


\section{INTRODUCTION}

Looking into the past, we can see how quickly we humans have taken advantage of our Earth's resources. The world was once a slow and simple place, where people travelled long distances through ships, walked to places, built everything with their bare hands. The first industrial revolution changed everything. We witnessed one of the biggest changes humanities had undergone in terms of mechanizing their work. The steam engine, one of the most important inventions in the history of mankind, although it had its caveats. Men started extracting coal exponentially and soon the entire industrial sector was running with the help of coal. At the end of the 18th century, we saw the second industrial revolution, where humans figured out ways to use gas, oil and electricity to their advantage.

Mankind, after just a few notable people's discoveries, had progressed substantially. Nearly all forms of the progress we humans have made, including computers, transportation, biology, economy have had an exponentially growing curve. Our planet is 4.5 billion years old; any system must reach an equilibrium after it has run its course with no interference.

The earth was in equilibrium for most of its existence. We, humans, have spent less than a per cent of earth's life here and have changed earth in unimaginable ways. What we do now will change the way we will be living in the next few decades. Huge changes are needed to be made for humans to survive on earth. Embracing sustainable goals will help us, humans, ensure a future for us all. The world will be a better place where humans don't take from the environment rather, live in conjunction with it or without it. Natural nonrenewable resources such as coal, oil, and gas, will run out shortly, so we will have to look for clean alternatives.

A sustainable environment will allow us to live a happy and healthy life. Reducing our carbon footprint is the least we can do to help. Engineers are one of the most important people when it comes to sustainable development, solving problems by applying their knowledge and refining existing technology to ensure that all our needs are met using sustainable practices. Engineers can design mass infrastructure, such 
as designing and building transportation systems that are good for the environment. They may help in finding new ways to recover and reuse existing resources to better make use of the waste we have.

Our research project tackles the biggest problem regarding the climate crisis, the transportation conundrum. Our transportation mediums are one of the largest contributors to global carbon emission levels. The model we have is an extension of an already working idea, the electric car. Our electric car uses supercapacitors to run which have a very high duty cycle, and are made using environmentally friendly resources. It is charged using solar panels through a wireless charging station. The goal of our project was to create something that has a closed-loop system, meaning there is no need for any external inputs to run our car. The solar panels take energy from the sun, provide it to the car, and the car can run without expelling any harmful gases, and with this, our cycle runs in a loop without damaging the environment.

\section{METHODOLOGY}

The design of our car is inspired by Tesla's Cyber truck, as it has a fairly minimal design while having a modern look. Our paper is an amalgamation of several other types of research which we reviewed extensively, to create a version of a future EV. We first worked on the idea of what realistically could be added to our version of the $\mathrm{EV}$ that would make it more complete, as a whole, for the user.

We looked into making our model primarily environmentally friendly, which would mean figuring out a way to charge it without using any fossil fuels or other unsustainable energy sources. Solar panels were the best and most efficient method to do that. We looked into papers that studied solar panels used for EV's to understand the economic as well as environmental factors. Charging time was another challenge, we wanted our power source to last as long as possible, consequently, we did not employ any of the fastcharging methods, as they would significantly reduce the battery's life span (Tomaszewska et al., 2019).

We explored ways to maximize battery efficiency by combining it with supercapacitors, which would 
additionally work as break recovery energy storage. To further improve the battery's efficiency, we allowed the supercapacitor to take over during periods of acceleration. The wireless power transfer system was added to give the user a seamless experience, where the car would enter the garage, it would start charging, being fully charged by the next day. This process helps combat range anxiety and gives users peace of mind. For each aspect of our car, we looked into what the prior research was telling us to ensure that our work was valid.

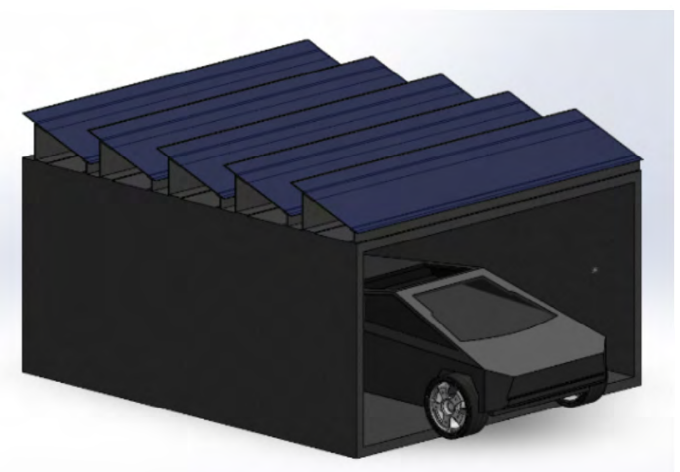

Figure 1. Wireless charging station and EV.

Source: own elaboration.

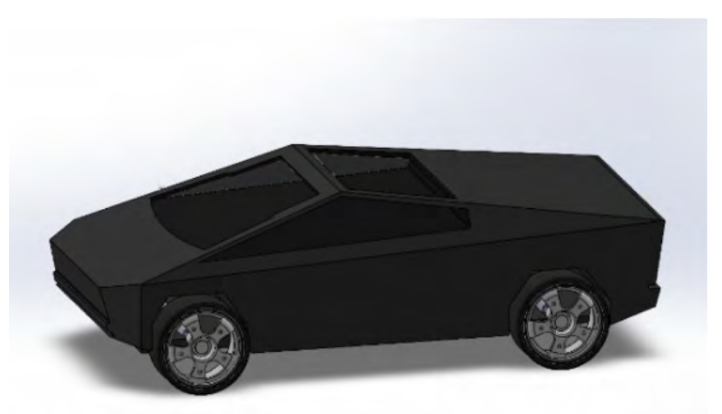

Figure 2. EV model inspired by Tesla Cyber Truck.

Source: own elaboration. 


\section{BACKGROUND STUDY}

When planning for this paper, we had to perform extensive research on every aspect of our model. Our idea was to build on the research done by Yoichi Hori (Hori, 2012). His research was regarding ideas for future EV development, where he mentioned how supercapacitors are the future due to their fast charging, high energy density, high duty cycle. In his paper he mentioned the use of quick charging systems, through a wireless power transfer system, discussing how cars would only need to stop for a few minutes for a full charge. Additionally. his paper considers motor usage, and several other technologies to use in conjunction with these systems. This paper provided a base to build on and produce a working model. After planning what we wanted to achieve, we had to verify proof of concept. A paper was published discussing their practical application of a wireless power transfer system for a sightseeing car (Ervin, 2015; Saeed et al., 2017). The car used a supercapacitor to hold its charge, charging after each tour. This research paper provided a detailed technical analysis of the wireless charging system while providing theoretical and practical findings.

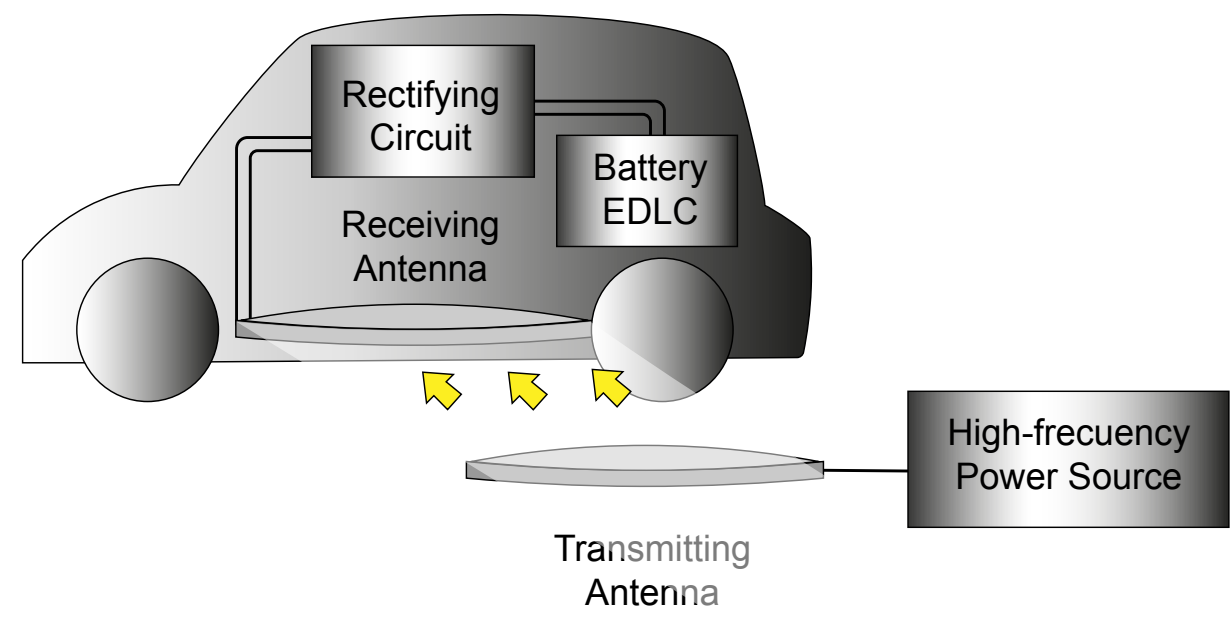

Figure 3. A representation of a wirelessly charged EV.

Source: (Hori, 2012). 
We had to consider if the current technology for supercapacitors is capable enough to run a car. The existing technology for supercapacitors is not quite adequate, however, development is continuing in the field, hinting at promising results. Currently, the best way to use supercapacitors is in conjunction with batteries. The research was done regarding this kind of amalgamation providing practical application of supercapacitor-battery run car while providing extensive information on each component in the system (Frenzel et al., 2011 ). It established all the advantages and disadvantages of the hybrid system and provided a clear plan of how this would be achieved.

The research was conducted regarding the idea of how feasible, using solar panels would be (Lee et al., 2017; Mouli et al., 2016). They discussed users wanting clean and green systems since electricity from companies uses up a substantial number of natural resources like coal and crude oil. The data regarding solar panels and their usage with EV's was immensely useful. They provided a complete analysis of solar energy production and how much an average car had charged given the size of the panels. Moreover, the papers considered solar power energy allocation helping realize how the power from the panels could be used for the home while the power for the car remains separately allocated for the car to charge it fully.

Throughout our research, we aimed to include components that were environmentally friendly in their making. The goal was to use materials that were repurposed or could be repurposed in the long run. The paper by Marichi et al. (2019), considered sustainable, clean energy and efficient storage devices. It predominantly explained the use of supercapacitors and how it was ideal that carbon-based waste materials be used to make electrodes for supercapacitors. This paper gave an excellent insight into how supercapacitors function and can work even better when made with carbon-based materials.

To know if supercapacitors would ever replace batteries in the future, we looked to Horn et al. (2019), where his paper explains the use of a supercapacitor and how it would be unviable to use them in their current state, though they did mention its uses in conjunction with batteries which was very useful as well. It provided a somewhat realistic prediction of how supercapacitors will progress in the future and was very inspired by the ideas it gave. 


\section{RESULTS}

Creating a model EV with features that were innovative, and convenient for real-world use was the goal of this paper. Dealing with such a complex design and feature set, our data-driven from several research papers has shown promising results with the way this car and its idea could function.

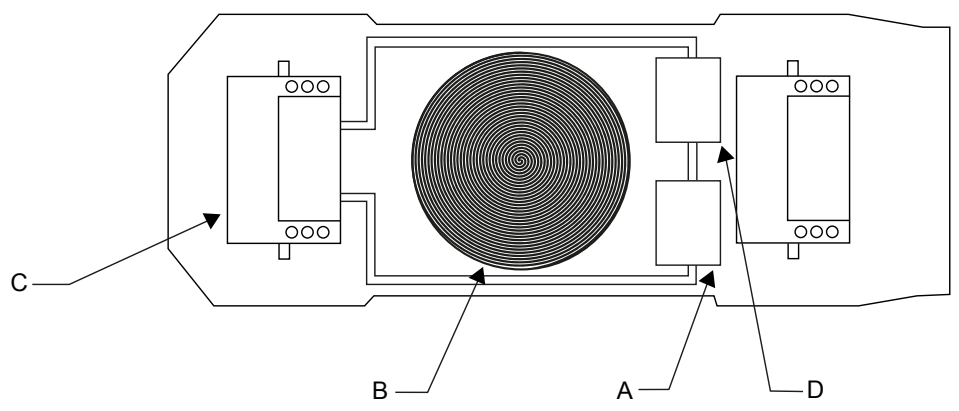

$$
\begin{aligned}
& \text { A - Supercapacitors } \\
& \text { B - receiving Antenna } \\
& \text { C - Inverter (Front and back) } \\
& \text { D - Rectifying Circuit }
\end{aligned}
$$

Figure 4. Internals of the model EV.

Source: own elaboration.

\subsection{COMBINATION OF SUPERCAPACITORS AND BATTERIES}

Despite supercapacitors having large duty cycles, an immensely high-power density and a long operating life, it is clear that present supercapacitor technology would be unable to make up for the requirement of driving for long distances. Hence the usage of batteries in conjunction with supercapacitors was proposed. Accelerating a car exerts strain on the battery causing it to consume energy at a faster rate, lowering its lifespan (Li \& Liu, 2019). A supercapacitor's high-power density allows it to supply and absorb large amounts of energy (Lee et al., 2017). We propose that whenever the car is accelerated for long periods, the supercapacitor is substituted as the energy source resulting in the battery operating only when speeds are somewhat stable. A system may be employed to smoothly alternate amongst the power sources without 
causing a delay. A similar idea was presented in Allègre et al. (2010), mentioning the energy absorbed by a brake energy recovery system would be stored in the supercapacitor, used to accelerate the car when it needs to move. Our idea allows the EV to take full advantage of the supercapacitor by giving it complete control of the car's acceleration - To achieve this future EVs require supercapacitors to have larger energy densities than the present ones. The use of Graphene could be presented as a potential solution for the energy density problem in supercapacitors (Ervin, 2015), although it may take time to develop.

\subsection{WIRELESS POWER TRANSFER SYSTEM}

Since, our power source consists of both batteries and supercapacitors, to increase charging efficiency, a charging system would need to be implemented that can take into account their equivalent resistance as they charge. We use findings from Li et al. (2017) to develop our design as it has proven to run at an efficiency of $88.05 \%$, with a constant current of $31.5 \mathrm{~A}$. Although, further study is required to create a more efficient design according to our requirements.

\subsection{USE OF SOLAR POWER FOR ELECTRIC VEHICLES}

Using an electric car instead of a gasoline car could result in an annual saving of \$1778 in fuel costs and reduce carbon emissions by an average of $38.5 \mathrm{~g} / \mathrm{km}$. In addition to this data, Mouli et al. (2016) discusses the various tax implications which gasoline-powered cars have to face, unlike EVs. Regardless of these economic and environmental advantages, power production in most countries is through burning fossil fuels. Charging a vehicle via electricity produced from nonrenewable sources accounts for $70.5 \mathrm{~g} / \mathrm{km}$ of $\mathrm{CO} 2$ per car on average. Electricity is a large expense in many countries, therefore factors to mass adoption issues of electric cars. Solar energy is the best solution, resulting in zero CO2 emissions as a whole, meanwhile being economically viable. The size and quantity of the solar panels would be as per the specifications and the manufacturer's recommendation. 


\section{CONCLUSIONS}

The goal of this project was to be able to realize our idea by researching and building upon proof-ofconcept papers. This entire project aims to create a self-sustaining closed-loop system. We were able to create an efficient design with eco-friendly materials and have its working be primarily sustainable. As our research dictated, supercapacitors in their current state will be best used in conjunction with a battery. A wireless charging station would make the switch from fuel-based vehicles to EV a significantly convenient experience. Using solar panels would save the consumers a considerable amount in electricity bills meanwhile reducing their carbon footprint. Making sustainable choices in all things is what we humans should aim for. As our life is short-lived, we must ensure future generations can have a life of comfort and ease

\section{REFERENCES}

Allègre, A. L., Bouscayrol, A., Delarue, P., Barrade, P., Chattot, E., \& El-Fassi, S. (2010). Energy storage system with supercapacitor for an innovative subway. IEEE Transactions on Industrial Electronics, 57(12), 4001-4012. https://doi.org/10.1109/TIE.2010.2044124

Ervin, M. H. (2015). Etching holes in graphene supercapacitor electrodes for faster performance. Nanotechnology, 26(23), 234003. https://doi.org/10.1088/0957-4484/26/23/234003

Frenzel, B., Kurzweil, P., \& Rönnebeck, H. (2011). Electromobility concept for racing cars based on lithium-ion batteries and supercapacitors. Fournal of Power Sources, 196(12), 5364-5376. https:// doi.org/10.1016/j.jpowsour.2010.10.057

Hori, Y. (2012). Novel EV society based on motor/ capacitor/ wireless - Application of electric motor, supercapacitors, and wireless power transfer to enhance operation of future vehicles. In 2012 IEEE MTT-S International Microwave Workshop Series on Innovative Wireless Power Transmission: Technologies, Systems, and Applications, IMWS-IWPT 2012 - Proceedings. https://doi.org/10.1109/ IMWS.2012.6215827 
Horn, M., MacLeod, J., Liu, M., Webb, J., \& Motta, N. (2019). Supercapacitors: A new source of power for electric cars? Economic Analysis and Policy, 61, 93-103. https://doi.org/10.1016/j. eap. 2018.08.003

Lee, S., Iyengar, S., Irwin, D., \& Shenoy, P. (2017). Shared solar-powered EV charging stations: Feasibility and benefits. In 2016 7th International Green and Sustainable Computing Conference, IGSC 2016. https://doi.org/10.1109/IGGG.2016.7892600

Li, L., \& Liu, Q. (2019). Acceleration curve optimization for electric vehicle based on energy consumption and battery life. Energy, 169, 1039-1053. https://doi.org/10.1016/j.energy.2018.12.065

Li, Z., Zhu, G., Jiang, J., Song, K., \& Wei, G. (2017). A 3-kW Wireless Power Transfer System for Sightseeing Car Supercapacitor Charge. IEEE Transactions on Power Electronics, 32(5), 3301-3316. https://doi.org/10.1109/TPEL.2016.2584701

Marichi, R. B., Sahu, V., Sharma, R. K., \& Singh, G. (2019). Efficient, Sustainable, and Clean Energy Storage in Supercapacitors Using Biomass-Derived Carbon Materials. In: Martínez, L., Kharissova, O., \& Kharisov, B. (eds.), Handbook of Ecomaterials. Springer, Cham. https://doi. org/10.1007/978-3-319-68255-6_155

Mouli, G. R. G., Leendertse, M., Prasanth, V., Bauer, P., Silvester, S., Van De Geer, S., \& Zeman, M. (2016). Economic and CO2 Emission Benefits of a Solar Powered Electric Vehicle Charging Station for Workplaces in the Netherlands. In 2016 IEEE Transportation Electrification Conference and Expo, ITEC 2016. https://doi.org/10.1109/ITEG.2016.7520273

Saeed, A., Ahmed, A., Junejo, F., \& Amin, I. (2017). Design of a small, cheap UUV for underwater exploration. In 2017 4th IEEE International Conference on Engineering Technologies and Applied Sciences (ICETAS), 1-5. https://doi.org/10.1109/ICETAS.2017.8277865 
Tomaszewska, A., Ghu, Z., Feng, X., O’Kane, S., Liu, X., Ghen,J.,Ji, G., Endler, E., Li, R., Liu, L., Li, Y., Zheng, S., Vetterlein, S., Gao, M., Du, J., Parkes, M., Ouyang, M., Marinescu, M., Offer, G., \& Wu, B. (2019). Lithium-ion battery fast charging: A review. eTransportation, 1, 100011. https://doi.org/10.1016/j.etran.2019.100011 


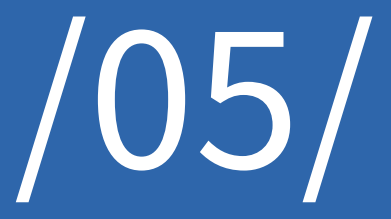




\title{
REMOTELY MEASURING AND CONTROLLING SPECIFIC PARAMETERS OF A PV MODULE VIA AN RF LINK
}

\author{
Ntombizanele Maqache \\ Central University of Technology, Free State, (South Africa). \\ E-mail:nsolfafa@cut.ac.za ORCID: https://orcid.org/0000-0001-9457-1573 \\ Arthur James Swart \\ Central University of Technology, Free State, (South Africa). \\ E-mail: aswart@cut.ac.za ORCID: https://orcid.org/0000-0001-5906-2896
}

Recepción: 05/07/2021 Aceptación: 15/10/2021 Publicación: 14/12/2021

Citación sugerida:

Maqache, N., y Swart, A., J. (2021). Remotely measuring and controlling specific parameters of a PV module via an RF link. 3C Tecnología. Glosas de innovación aplicadas a la pyme, 10(4), 103-129. https://doi.org/10.17993/3ctecno/2021. v10n4e40.103-129 


\section{ABSTRACT}

The efficiency of PV modules is affected by a number of factors, including installation parameters and the module surface temperature. Installation parameters of PV modules focus primarily on the tilt and orientation angles, which have to be considered for optimum output power. Furthermore, the operating temperature of a PV module must be kept within certain limits, in order to obtain optimum electrical energy efficiency, depending on the module used. The purpose of this study was to measure the instantaneous surface temperature, voltage and current of a remote PV module in order to monitor its output power. An energy monitoring system was developed that received measurement data over an RF link. The PC transceiver of the system featured a CG1101 RF transceiver connected to the PG via an Arduino UNO, using a USB cable. The PV transceiver featured an Arduino Mega 2560, connected to a CG1101 RF transceiver to make the ST board, which contained all the sensors of the system. In addition, a graphical user interface was developed for sending and receiving measurements between the PC transceiver and the PV transceiver. The PV module voltage and current data was verified using a Fluke 115 DMM. The results showed a 4.9\% error percentage for voltage measurements and a 3.9\% error percentage for current measurements. Furthermore, a 29-day period of data showed the surface temperature to rise significantly higher than the ambient temperature during the day, indicating that there was considerable heating of the PV Module when there was solar radiation. The system could be used to compare the effect of cooling the PV module on the output power as the orientation angle is adjusted.

\section{KEYWORDS}

PV Module, Voltage, Current, Surface Temperature. 


\section{INTRODUCTION}

Fifty percent of the overall power consumption in the Information and Communication Technology (ICT) field is dedicated to telecommunication networks (Koutitas \& Demestichas, 2010). In fact, research has shown that a mobile base station uses an average of $36000 \mathrm{kWh}$ per year. The study included a sample of 6 mobile base stations in the center of Italy for shelter, room and outdoor types (Spagnuolo $e t$ al., 2015). The 2018 Telkom SA integrated report reflects $563055930 \mathrm{kWh}$ electricity consumption by the telecommunications giant in South Africa (Telkom, 2018). In addition, a forecast study estimates that communication technology will consume 51\% of the world's electricity in 2030 (Andrae \& Edler, 2015). This amplifies the need for more renewable and sustainable sources of electricity.

Photovoltaic (PV) modules are devices that convert solar energy directly into electrical energy without requiring mechanical energy and without producing greenhouse emissions. PV modules undergo performance characterization in Standard Test Conditions (STC) by primarily measuring its voltagecurrent (I-V) curve (Schwingsshackl et al., 2013). One study found that the operating temperature plays a key role in the process of PV conversion (Swapnil, Jatin, \& Bharath, 2013). In addition, the aforementioned authors concluded that there is a linear dependence of electrical efficiency, and thus output power, of a PV module with regard to the operating temperature of a module. PV's only convert $4-17 \%$ of the solar energy to electrical energy, the rest is converted to heat energy that is not used (Bai et al., 2016). Solar radiation and other weather parameters, have an effect on a PV module's operating temperature, and as such on its Cell Temperature (Tc) (Swapnil et al., 2013). Ambient temperature (Ta) is defined as the temperature of the air around the PV module (Bhattacharya, Chakraborty, \& Pal, 2014; Liu et al., 2015). The agreement across board is that the open-circuit voltage decreases considerably (about $2.3 \mathrm{mV} / \mathrm{C}$ ), while the short circuit current only decreases somewhat with increased PV module temperature (Bai et al., 2016).

As such, field measurements of the voltage and current of a PV module, allow more accurate data to be collected for practical operating conditions that differ slightly from the Standard Test Conditions, in 
order to optimize the overall system performance. Researchers used a simple approach of a digital multimeter to measure the voltage and current in a study that increased the efficiency of a PV module by $47 \%$ using cooling (Peng, Herfatmanesh, \& Liu, 2017). This approach is not an automated one and requires one to physically save the measurements from the multi-meter. A more complex combination of super capacitors, step-up and step-up converters were used to acquire voltage measurements in a study that monitored PV modules using wireless sensor networks (Prieto et al., 2014). The aforementioned study made use of ACS711 current sensors from Allegro, an 8-bit PIC microcontroller from Microchip for processing and XBee PRO 802.15.4 for communication. The study was successful in obtaining real-time measurements of PV modules for monitoring purposes. Alternatively, the voltage divider is a simpler and cheaper method that has been used in PV monitoring systems to obtain voltage measurements effectively, and in real-time (El Hammoumi et al., 2018; Kekre \& Gawre, 2017). A variety of sensors have also been used in PV monitoring systems to measure temperature (Atsu et al., 2020), which includes the LM35 and Pt-100 sensors. Alternatively, a thermographic camera can be used to measure the temperature distribution over the module's surface (Nedelchev \& Zhivomirov, 2020), although it is again a manual approach. An automatic PV module monitoring system was designed in Spain with a complex control unit that connects a PV system physically to a computer to control the measuring circuit (Ortega et al., 2018). This design proved to be both complex and expensive.

The monitoring system presented in this paper aims to be both a non-complex and cost-effective solution as it eliminates physically connecting the PV module and the data recording system. The design and development of a cost-effective remote measuring and monitoring system that will record the voltage, current and surface temperature of a remote PV module via a Radio-Frequency (RF) link is contained herein. Measuring these remote parameters instantaneously will allow effective monitoring in order to maintain a high output power. The sections that follow will explore the sensing technologies used to obtain measurements as well as the results obtained over a given period. The communication technology 
used to send and receive data to a remote PV module will also be presented. Lastly, this paper will show the user interface used for the synergy of all the system parameters and controls.

\section{SYSTEM DESIGN AND PRACTICAL SET-UP}

The block diagram contained in Figure 1 shows the overall setup of the system design for remotely measuring current, voltage and temperature. Block 1 is the Master Transceiver (MT) where the user can see the real-time sensor data displayed on the PG that is sent from block 2 which is the Slave Transceiver (ST) responsible for collecting data using a microcontroller. Block 3 shows all the parameters of the PV module that are collected by the microcontroller.

When measurements are acquired from the PV module, there needs to be a method of processing and saving the data for monitoring or analysis. Hence the need for a microcontroller where three options were considered. Firstly, Rasberry Pi 3 model B+ is the latest release in the Rasberry Pi 3 range that makes use of the Broadcom BCM2837B0 processor with $1.4 \mathrm{GHz}$ operating speed. Although a RAM of $1 \mathrm{~Gb}$ makes it attractive, the drawback is that this board requires an external ADC, which will contribute to the cost and complexity of the design (Rasberry Pi, 2018). Secondly, the BeagleBone Black incorporates the TI Sitara AM3358 processor at the operating speed of $1 \mathrm{GHz}$ and 512Mb of RAM with six analog input pins. This option is more expensive and more complex to implement. Lastly, the Arduino Uno is based on the ATmega328 microcontroller, has 16 digital input / output pins, six analog inputs and a USB connection. It was chosen for designing a data logger for a PV system for its simplicity and modularity, in comparison with other boards (Arduino, 2018; Fuentes et al., 2014). The Arduino platforms allow for easy learning and adaptation, because it is open ware, as such there are modules and libraries readily available on the internet. 


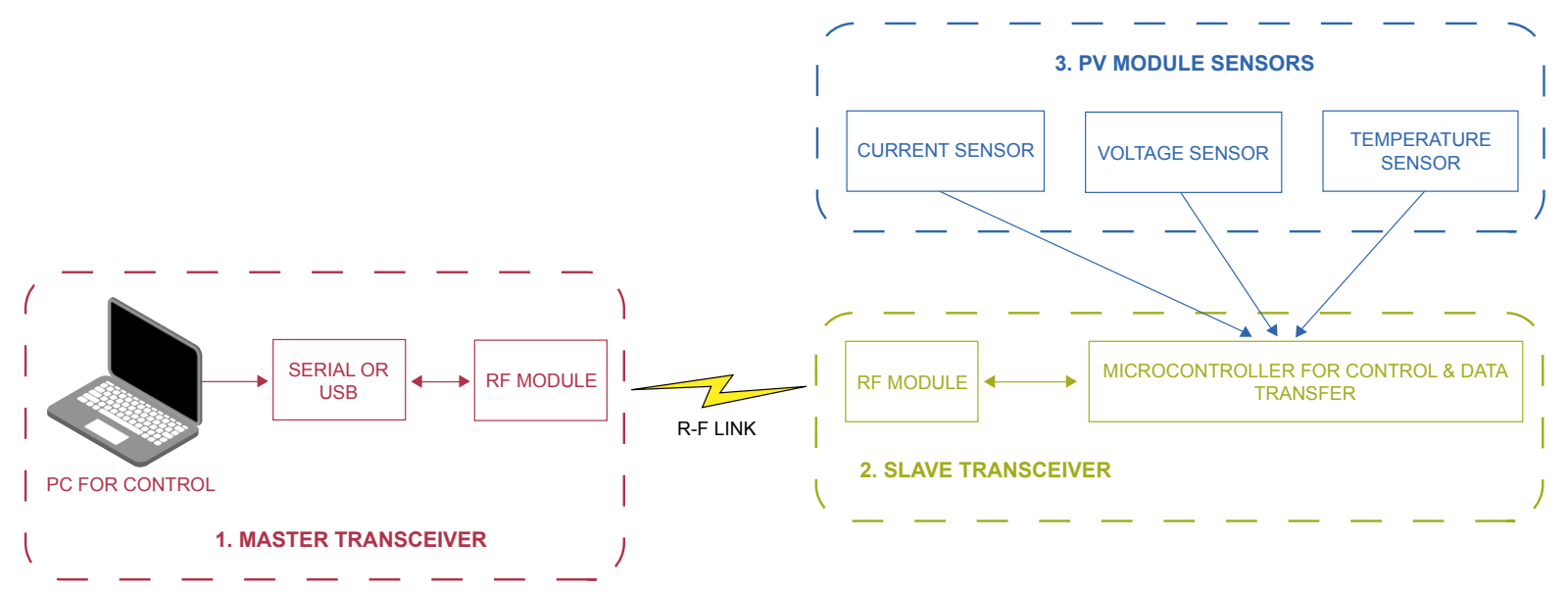

Figure 1. Block diagram of the practical set-up.

Source: own elaboration.

Wireless technology (the RF Link in Figure 1) is used to transfer information between two or more points that are not physically connected to form wireless communication. Wireless technologies prove useful when it comes to accessing data from a remote site that is without electricity or telephone lines. Wireless communication can be achieved through either radio frequency, microwave or infrared. An RF transceiver module is an integrated circuit that transmits and receives radio signals on a given carrier frequency (433 MHz as an example). The CG1101 is an example of such a module. It has different communication modes that can be changed by command. In addition, it can transmit over distances of up to $500 \mathrm{~m}$ in open-air line of sight without any obstacles to absorb radio signals at a rate of about 600 kBps (Texas Instruments, 2018). The usefulness of RF modules in remote-sensing and control is widely accepted in many industries. In wireless communication, power consumption is increased with bigger communication distances. It is therefore required for wireless communication to consume minimal power for remote sites. This is why RF modules are also widely used in renewable energy system monitoring, as they have very low power consumption and also for their low-cost and wide open-air range capabilities 
(Kama et al., 2017). Added to these advantages, they eliminate the need for physical wiring between two points that can complicate the installation of the energy monitoring system.

PV module sensors of Figure 1 include the voltage divider, the ACS712 and the DHT11. The voltage divider is commonly used in PV data acquisition to obtain higher voltage measurements because it is non-complex and inexpensive. The voltage divider is designed such that its output is proportional to the input voltage and small enough to be processed by a microprocessor. For current measurements, Hall Effect current transducers (LEM LA100-P, LA55p, Honeywell Microswitch CSLA1CF) have been used to measure current for more complex PV applications (Belmili et al., 2010; Tina \& Grasso, 2014). The ACS712 has a precise proportional voltage provided by the low-offset, chopper-stabilized BiCMOS Hall IC, which is programmed for accuracy after packaging (Allegro Microsystems, 2006). The DHT11 humidity and temperature sensor is a semiconductor thermometer device that is made up of a resistive type humidity measurement component and an NTG temperature measurement component. It connects to a microcontroller for excellent quality, fast response, anti-interference ability and cost-effectiveness (D-Robotics, 2010). Their digital output can be connected to a microcontroller without complex circuitry, which contributes to the overall cost of the setup.

\subsection{THE GRAPHICAL USER INTERFACE (GUI)}

The graphical user interface is used to connect the user (Master Transceiver) to the PV module sensors (Slave Transceiver) using the RF link as shown in Figure 1. The GUI is designed using Visual Studio C\# with its purpose being for the end user of the system to visually see the data being sent from the ST or to interact with the system. Figure 2 shows the GUI with numbered items that are used to illustrate its functionality. The numbered items of the GUI are presented below with their functionality explained: 
1. Serial port settings to be selected by the user.

The serial port settings are obtained from combo boxes where the user selects the appropriate port name, baud rate, parity, stop bits and handshake.

2. Tabs that can be selected to view different data representations.

The data grid sorts the data received into the 7 relative columns with the last column being the time the measurements are received. The columns are named after the measurement reading they collect; PV voltage, Battery voltage, Load voltage, PV current, Battery current, Load current and Temperature. The data grid is displayed in the second tab of the GUI that is named "Live table". The third tab displays the chart representation of all the PV measurements, this being the PV voltage vs time, PV current vs time, Temperature vs time and Power vs time. Tab four and five show the same charts (except for temperature) for the battery and the load.

3. The button used to turn on the water sprayer for 5 seconds at the PV module.

This functionality could be used to control the water sprayer used for cooling the PV module when the surface temperature gets too high. When clicked, a signal is sent to the ST to activate for 5 seconds.

4. Buttons used to move the PV module either left or right by $10^{\circ}$ to adjust the orientation angle. The orientation angle could be varied using these buttons to achieve the desired angle. When these are clicked, a signal is sent to the ST to either extend or retract the actuator for a set period. 


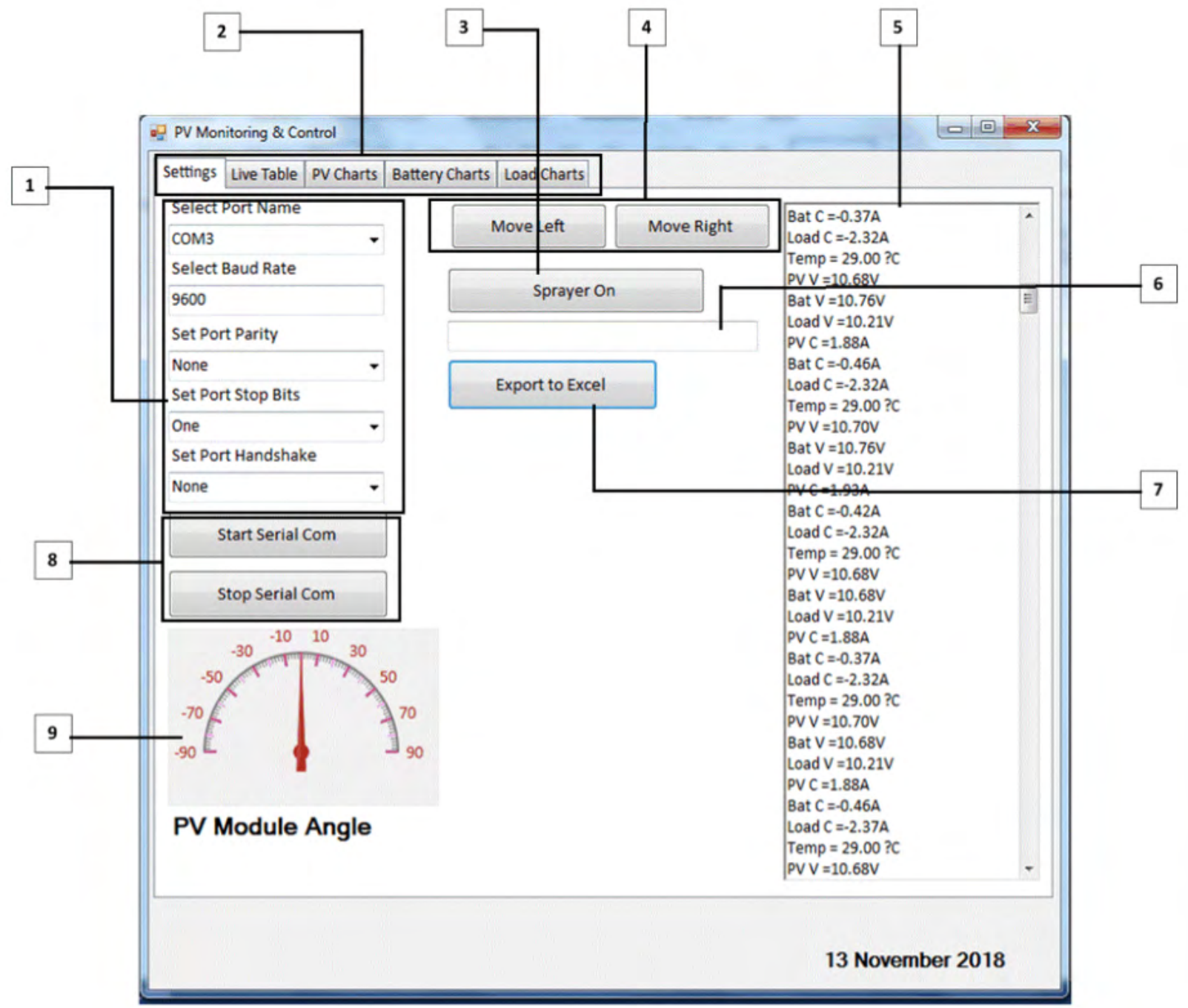

Figure 2. User interface.

Source: own elaboration. 
5. Displays the real time measurements as they are received from the ST.

Measurements received by the MT from the ST are displayed in this text box in rea-time and loaded in the live table in the GUI.

6. Displays commands that are sent to the ST when buttons are clicked for the water sprayer and actuator.

This enables the user to see the status of the control commands to avoid unwanted repetition.

7. The button that is used to send data to an excel sheet and save as a predetermined file name.

The export to Excel method is called after every 100 rows and when the user clicks the button. When this is done, an Excel file is created named "ExportedFromDatGrid". The file is saved to the path specified that includes the day's date and binary time format which ensures a unique file name each time.

8. Buttons used to either start or stop serial communication between the MT and the ST.

Communication between the MT and the ST is initiated or terminated by these buttons, giving the user control over when to start recording measurements.

9. Displays the real time orientation angle of the PV module.

This gauge displays the orientation angle of the PV module as it is adjusted either left or right by the control commands.

\subsection{MASTER TRANSCEIVER BOARD}

The GUI uses the MT to interface the user at the PC with the measurement system at the PV module (ST). The MT is responsible for receiving measurements and sending commands over the RF-link as well as saving it on the PC. The MT board in Figure 3 is designed to plug into the Arduino UNO board that connects to the PC using the USB port. 


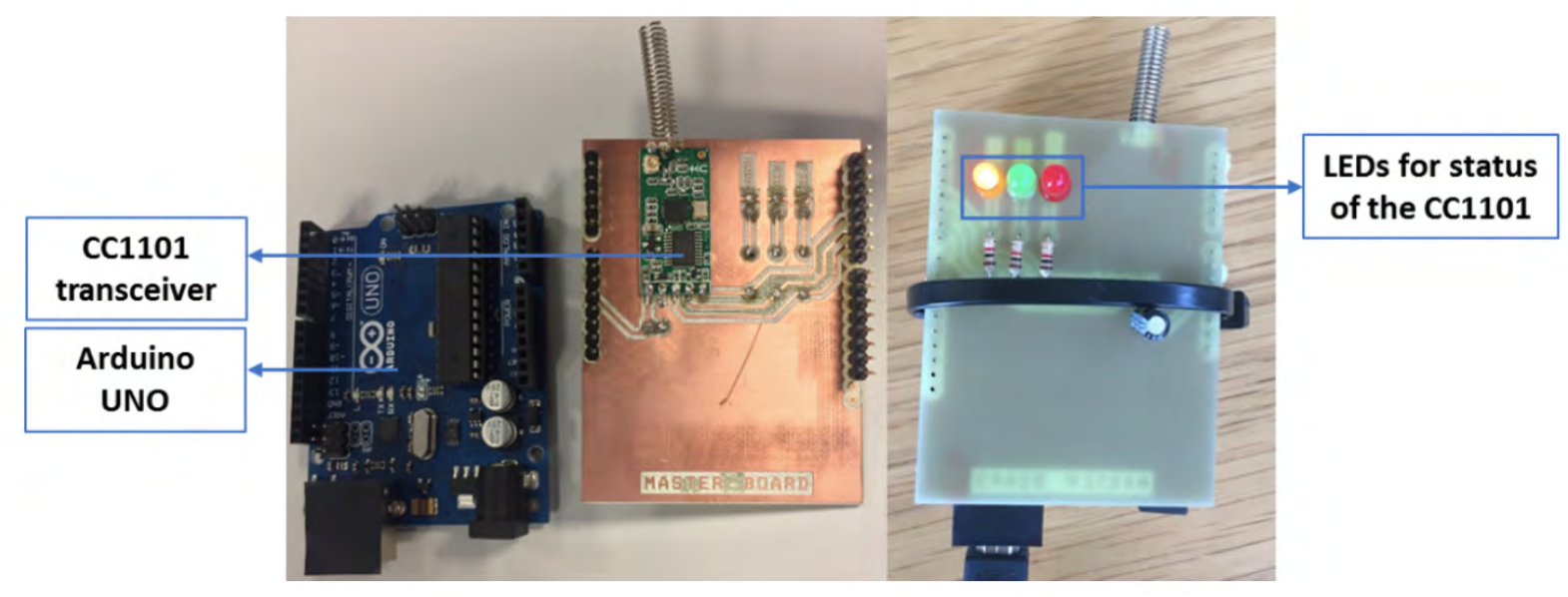

Figure 3. Arduino and Master Transceiver.

Source: own elaboration.

It houses the CG1101 transceiver for wireless communication with the three LEDs indicating the mode of the transceiver device; red being idle, green being receive data and yellow being transmit data. The microcontroller was only used for the wireless communication; hence the Arduino Uno was chosen because not many output pins were required for this function and for its simplicity, low cost and modularity.

\subsection{SLAVE TRANSCEIVER BOARD}

The MT receives measurements of the PV module from the ST to display on the GUI. The ST board (Figure 4) houses the second CG1 101 and the three sensors on the PV module side. The Arduino Mega that is used as the microcontroller has the same processing speed as the Arduino Uno with more RAM $(8 \mathrm{~Kb})$ and $\mathrm{I} / \mathrm{O}(54)$ pins allowing more data to be processed in and out by the microcontroller. This transceiver board was developed as a shield for the microcontroller and connects it to the voltage, 
current and temperature sensors that obtain data from the PV module, battery and the load. This data is transmitted to the MT board.

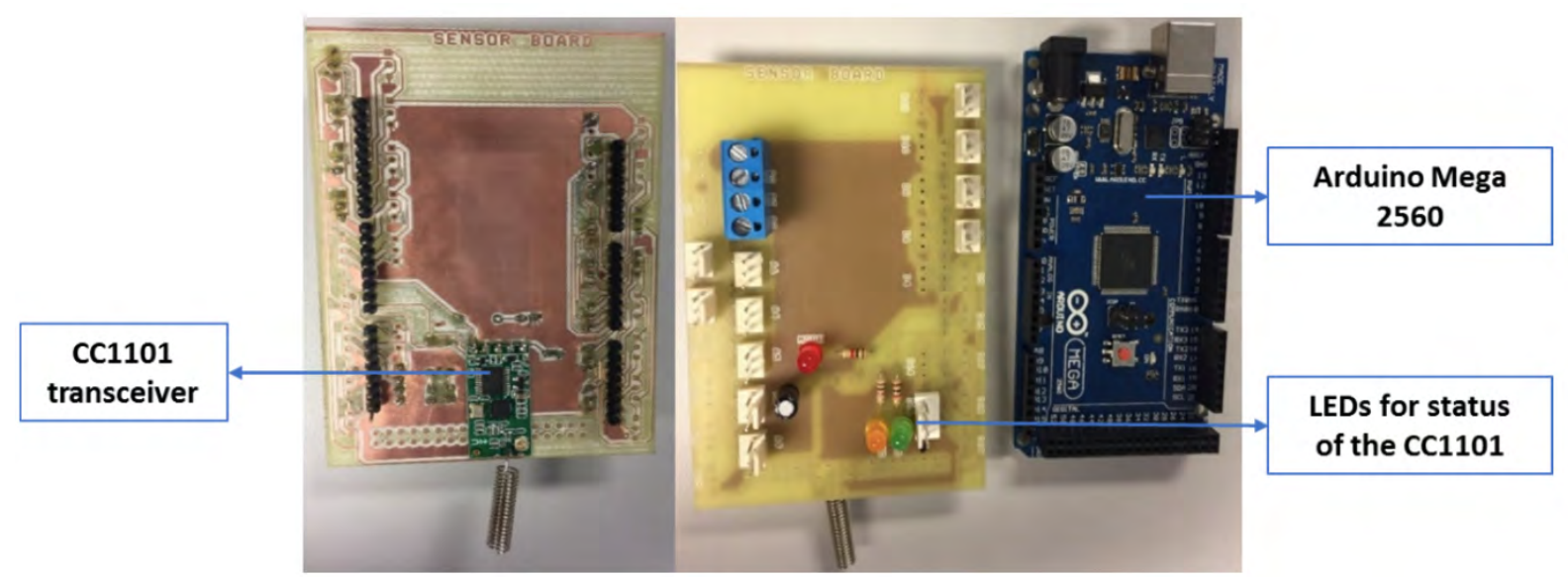

Figure 4. Slave Transceiver Board.

Source: own elaboration.

The measurements from the sensors are sent to the serial port of the Arduino Mega 2560. The transmitting device, CG1101 transceiver RX and TX pins are connected to this Arduino's serial port 0 at pin 0 and 1 respectively. This means that the measurements that are sent to the serial port of the Arduino Mega 2560 are then transmitted by the CG1101 transceiver. When the Arduino Mega 2560 is connected to a PC using a USB cable, terminal software can be used to display these measurements on the serial port of the PC through the USB port. This feature might be used in environments that are not remote and do not require wireless transmission.

\subsection{SLAVE TRANSCEIVER SENSORS}

Measurements are obtained using sensors connected on the ST board; they were designed to fit onto the Arduino Mega 2560 which processes the signals. Voltage dividers are used to obtain higher voltage 
measurements in a noncomplex and inexpensive manner, and are commonly used in PV data acquisition (Tina \& Grasso, 2014). The voltage divider is designed such that its output $\left(V_{\text {OUT }}\right)$ is proportional to the input voltage $\left(V_{P V}\right)$ and small enough to be processed by a microprocessor. The output of the voltage divider is calculated by:

$$
V_{\text {out }}=\left(\frac{10 K \Omega}{47 K \Omega+10 K \Omega}\right) \times V_{P V}
$$

Where $V_{P V}$ is the voltage from the PV modules 4 x SD ECO PLUS $10 \mathrm{~W}$ PV modules connected in parallel). The open circuit voltage $\left(V_{O C}\right)$ for these is $20.8 \mathrm{~V}$ and the short circuit current $\left(I_{S C}\right)$ is $0.78 \mathrm{~A}$. The Arduino Mega 2560 analog input pins can measure voltages from ground to $5 \mathrm{~V}$, supplying these pins with anything more will damage them. As such, voltage dividers are used to sense the voltages of the PV module, battery and load, while fuses are used to protect the circuitry against any unwanted currents.

$V_{\text {OUT }}$ from these sensors is connected to the 3 analog pins of the Arduino Mega 2560 respectively. The microcontroller then uses a programmed algorithm to process the voltage divider output and convert it to a relative voltage.

Hall-effect current transducers have been used to measure current for more complex PV applications (Tina \& Grasso, 2014). The Allegro ACS712 sensor comprises a precise, low-offset, linear Hall sensor circuit with a hall element. A precise, proportional voltage is provided by the low-offset, chopperstabilized BiCMOS Hall IC, which is programmed for accuracy after packaging (Allegro Microsystems, 2006). The analog input of the Arduino from the sensor is used in the formula below in order to arrive to the current reading:

$$
I=\frac{\left(\frac{\text { PinRead }}{1023} \times 5000\right)-2500}{100}
$$

PinRead is the analog input, the 1023 is the 10-bit resolution of the ADC and the 5000 is the reference voltage in $\mathrm{mV}$. Because the offset of the current sensor is $2500 \mathrm{mV}$, it must be subtracted to arrive to the actual current in $\mathrm{mA}$. 
The DHT1 1 humidity and temperature sensor is a semiconductor thermometer device that is made up of a resistive type humidity measurement component and an NTC (Negative Temperature Coefficient) temperature measurement component. It connects to a microcontroller for excellent quality, fast response, anti-interference ability and cost-effectiveness (Gay, 2018). This digital sensor was used to develop a humidity and temperature remote sensing system that was cost-effective and fast for real-time operations (Randhir \& Karhe, 2015). It can measure temperatures of up to $50^{\circ} \mathrm{C}$ with the accuracy of $+-2^{\circ} \mathrm{C}$. The temperature sensor also connects to the ST board and gives real time temperature of the PV module's surface in Degrees Celsius $\left({ }^{\circ} \mathrm{C}\right)$. As established in the previous section, the surface temperature of the PV module is important to its efficiency.

\section{METHODOLOGY}

The experimental set-up included the PV module, battery and 12 V LED flood light connected to a programmable solar charge controller on a balcony of a building at the Central University of Technology, Free State. The site is located in the city of Bloemfontein, South Africa where the latitude is -29.087 and the longitude is 26.154. The PV voltage and current were measured between the charge controller and the PV module. The battery voltage and current measurements were acquired between the battery and the charge controller. The temperature is a measurement of the PV module surface temperature and was obtained from the sensor that was attached to the back of the PV module. Measurement data was acquired every 100 seconds from the ST via RF using the MT and saved to an MS Excel sheet using the GUI. The data in MS Excel was analysed using Pivot Tables and then represented using line graphs. The results of the PV voltage and current are presented below for a cloudy and sunny day in September, as well as surface temperature measurements for a 29 day period in July and August of 2019. July and August are winter months where temperatures have been seen to go below $0^{\circ} \mathrm{C}$ whereas September is spring where warmer days can be found. 


\section{RESULTS}

\subsection{RESULTS OF THE PV MODULE VOLTAGE AND CURRENT MEASUREMENTS VERIFIED BY DMM}

Experimental results are presented here for different weather conditions with the load connected. The SD eco plus $10 \mathrm{~W}$ PV module was used with the rated parameters shown in Table 1 that are obtained under Standard Testing Conditions (STC). Four of these modules were connected in parallel, giving the expected parameters of Table 1.

Table 1. PV module parameters.

\begin{tabular}{|c|c|}
\hline STC parameters for one PV module & STC parameters for four PV modules in parallel \\
\hline $\mathrm{I}_{\mathrm{mp}}$ (maximum power current) $=0.61 \mathrm{~A}$ & $\mathrm{I}_{\mathrm{mp}}=2.44 \mathrm{~A}$ \\
\hline $\mathrm{V}_{\mathrm{mp}}$ (maximum power voltage) $=16.5 \mathrm{~V}$ & $\mathrm{~V}_{\mathrm{mp}}=16.5 \mathrm{~V}$ \\
\hline $\mathrm{I}_{\mathrm{sc}}$ (short circuit current) $=0.78 \mathrm{~A}$ & $\mathrm{I}_{\mathrm{sc}}=3.12 \mathrm{~A}$ \\
\hline $\mathrm{V}_{\mathrm{oc}}$ (open circuit voltage) $=20.8 \mathrm{~V}$ & $\mathrm{~V}_{\mathrm{oc}}=20.8 \mathrm{~V}$ \\
\hline Peak Power $=10 \mathrm{~W}$ & Peak Power $=40 \mathrm{~W}$ \\
\hline
\end{tabular}

Source: own elaboration.

A Fluke 115 digital multimeter (DMM) was used to verify the voltage and current measurements from the voltage divider and ACS712 sensors on the PV module transceiver. In Figure 5, a spreadsheet of sensor measurements obtained from the PV module transceiver for 27 September 2019 is observed, where a voltage and current reading was compared to a DMM voltage and current reading.

The accuracy of the voltage and current sensor measurements was evaluated by calculating the percentage error between the sensor measurements and the DMM readings as follows: 


$$
\% \text { error }=\frac{\text { sensor reading }-D M M \text { reading }}{D M M \text { reading }} \times 100
$$

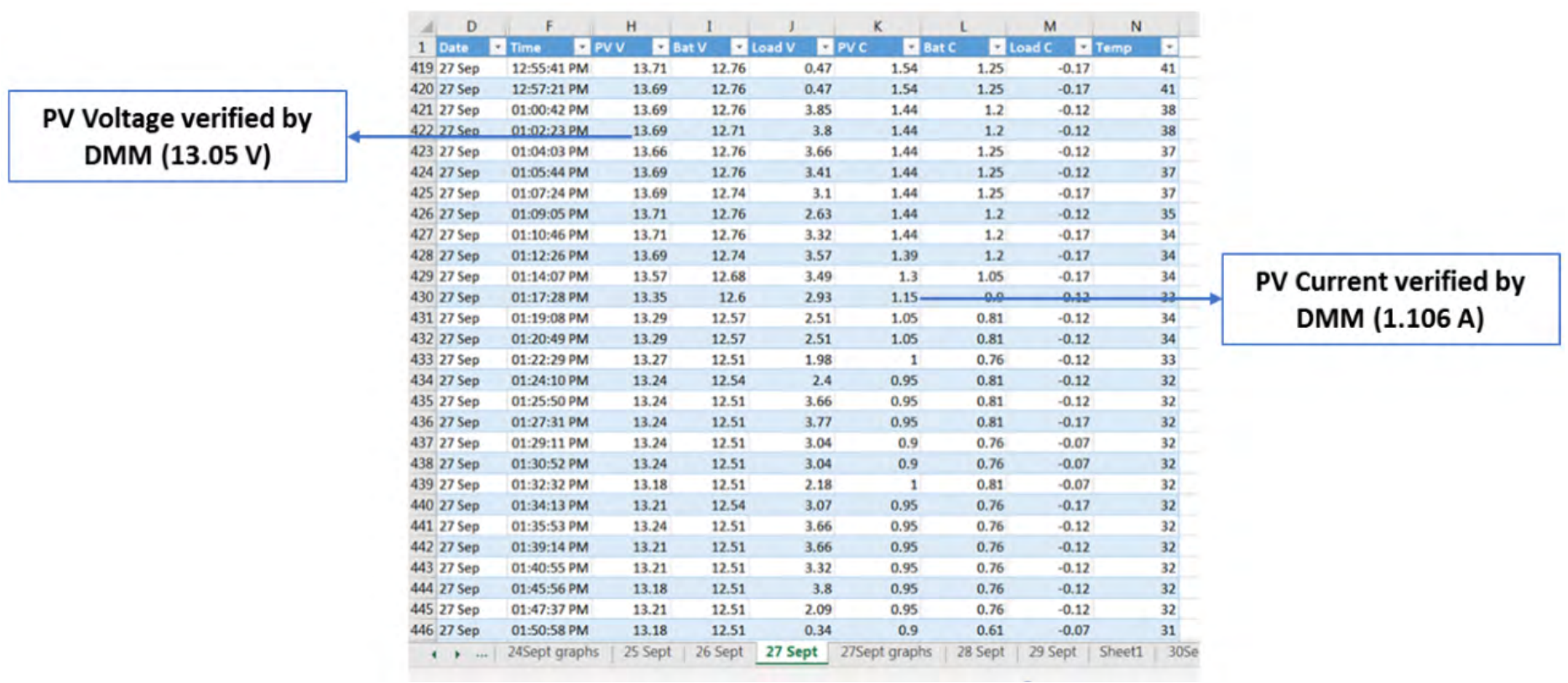

Figure 5. PV voltage and current measurements verified using a DMM.

Source: own elaboration.

The PV voltage of $13.69 \mathrm{~V}$ from the PV module transceiver and 13.05 V from the DMM were used in equation 3 to give an error percentage of $4.9 \%$. In addition, the error percentage for the current reading was calculated using the PV current of 1.15 A from the PV module transceiver and 1.106 A from the DMM, giving a value of $3.9 \%$. A percentage error of between $-10 \%$ and $+10 \%$ has been found to be acceptable for these type of measurements (Ertekin \& Yaldiz, 2000). 


\subsection{RESULTS OF THE PRACTICAL SETUP MEASUREMENTS OF PV VOLTAGE AND CURRENT OVER SEVEN DAYS}

Measurement data was acquired every 100 seconds from the ST via RF using the MT continually for a period of seven days. The data stored by the GUI was processed using pivot tables and summarized to hourly maximums. The daily PV voltage curve for the period above is presented in Figure 6 where the voltage can be observed to be higher for the days where the load is switched off. The PV module terminal voltage reaches $13.8 \mathrm{~V}$ when the load is on. When the load is switched off by the solar charge controller, the battery then acts as a load and draws current from the PV module. The terminal voltage the PV module, in this case, reaches is $15.44 \mathrm{~V}$ when the LED load is switched off and the battery is charging. Both values of PV voltage are less than the rated maximum power voltage of $16.5 \mathrm{~V}$, which indicates that the process of measuring is satisfactory. Hourly maximum measurements of PV voltage for 24 September show a maximum of $12.76 \mathrm{~V}$ at $12 \mathrm{pm}$. Hourly maximum PV voltage for 27 September show a maximum of $13.8 \mathrm{~V}$ at $10 \mathrm{am}$. The maximum terminal voltage of the PV module is less than the rated maximum power voltage throughout the presented period.

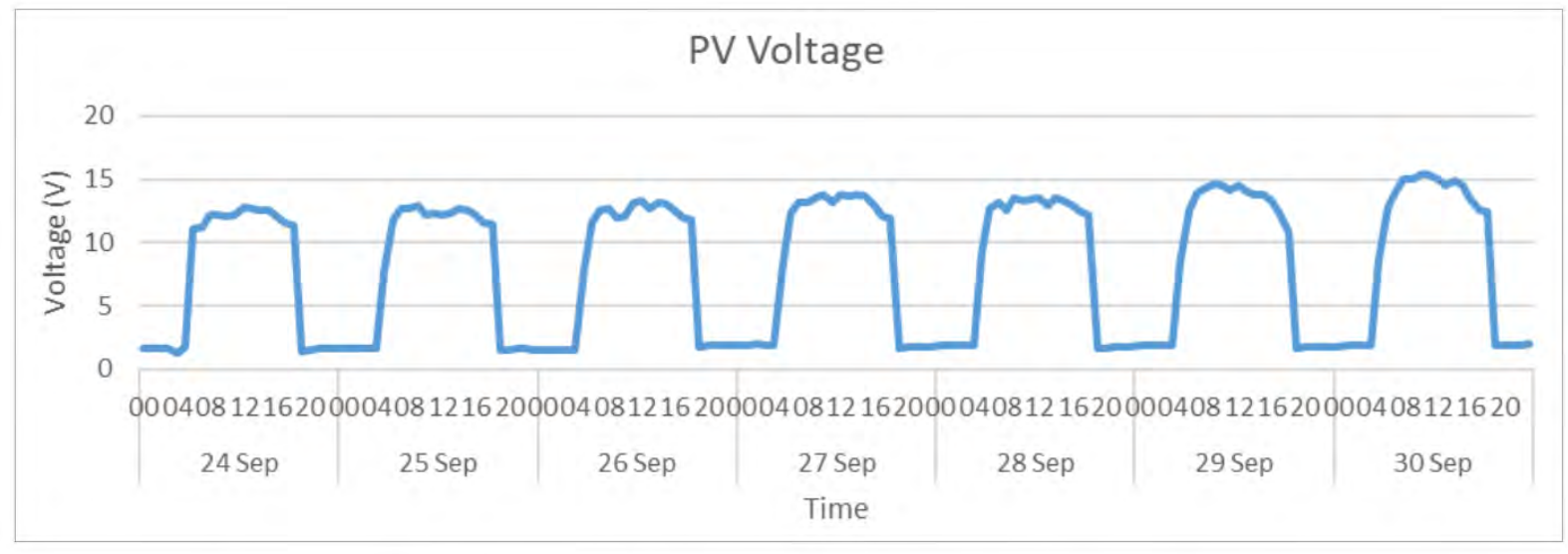

Figure 6. Hourly maximum of PV voltage from 24 to 30 September 2019.

Source: own elaboration. 
Daily maximum PV current is presented in Figure 7 from 24 to 30 September. The diagram shows that the maximum current recorded was less than the rated $\mathrm{I}_{\mathrm{mp}}=2.44 \mathrm{~A}$ for the said period. The highest maximum PV current is 2.43 A on 28 September and the lowest recorded maximum PV current 1.98 A on 29 September.

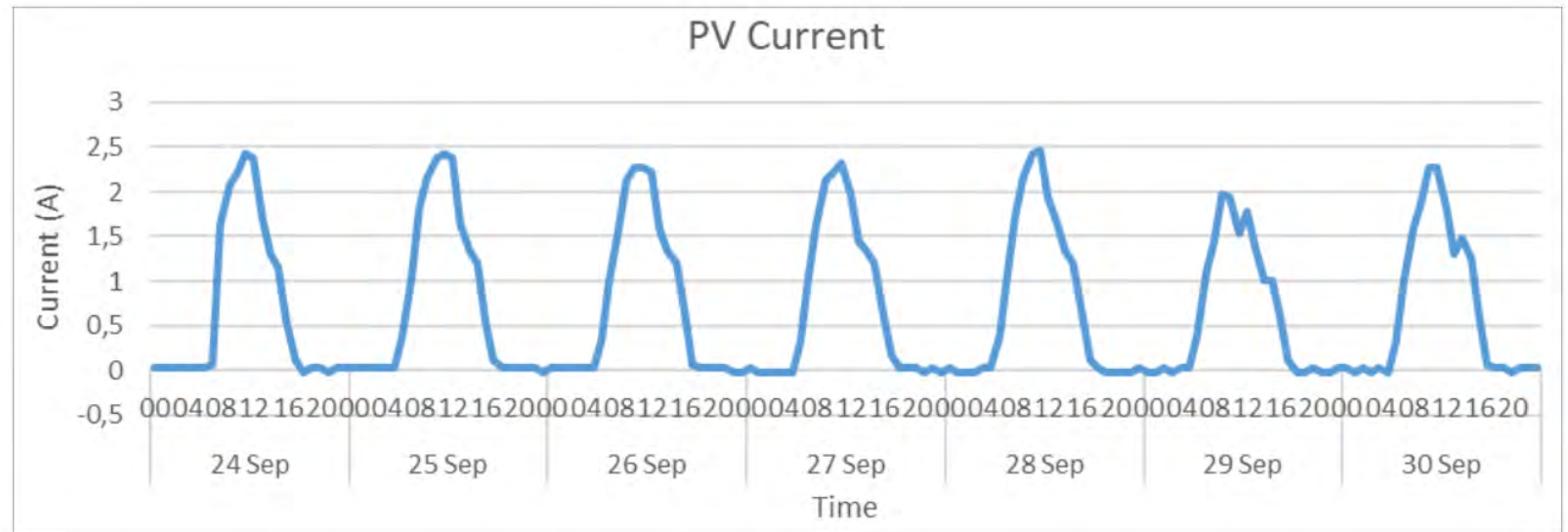

Figure 7. Hourly maximum of PV current from 24 to 30 September 2019.

Source: own elaboration.

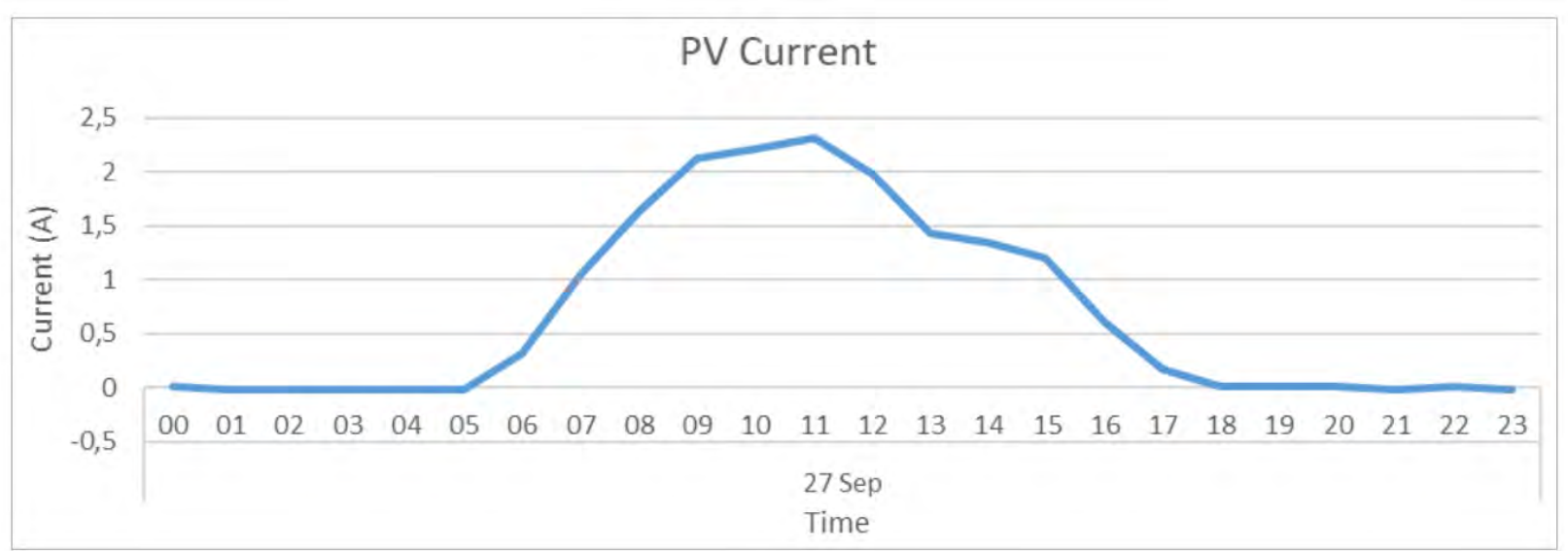

Figure 8. Hourly maximum of PV current for 27 September 2019 (Sunny day).

Source: own elaboration. 


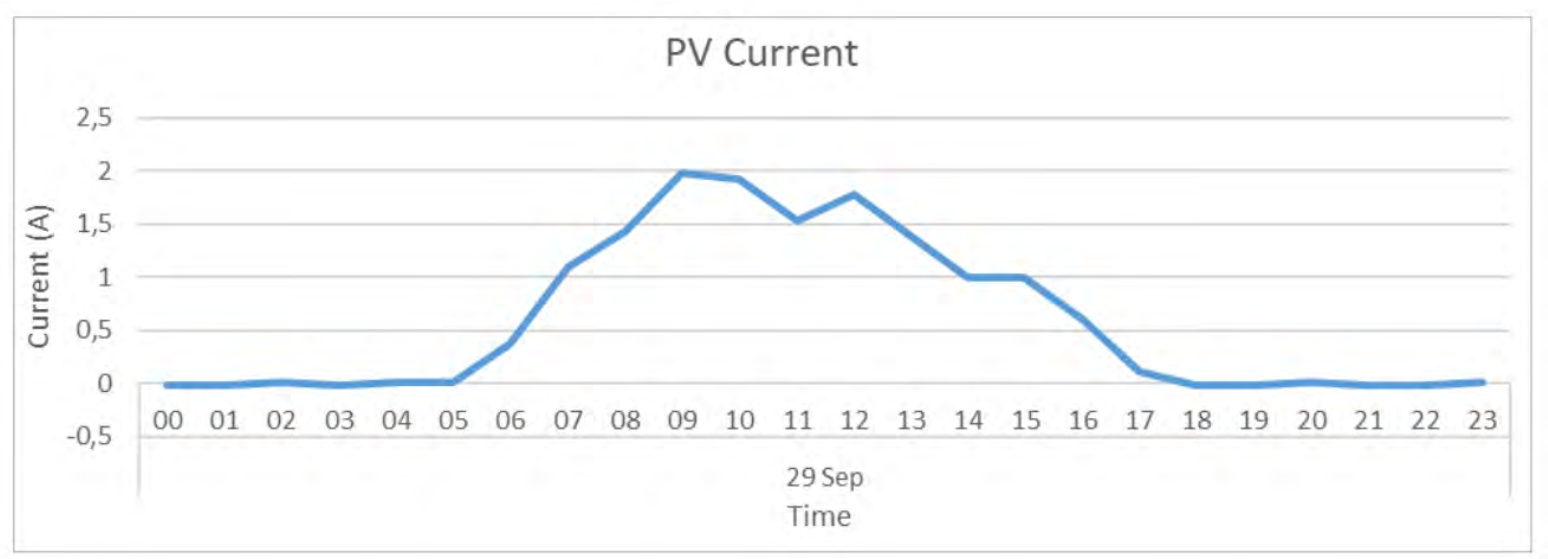

Figure 9. Hourly maximum of PV current for 29 September 2019 (Cloudy day).

Source: own elaboration.

A closer look at the daily performance shows hourly maximum PV currents for a sunny day on site (Figure 8) and for a cloudy day (Figure 9). The measurements reflect the maximum current drawn from the PV module as 2.32 A at 11 am for the sunny day and $1.98 \mathrm{~A}$ at 11 am for a cloudy day. Both currents are less than 2.44 A maximum power current of Table 1, suggesting that the measurement process is satisfactory.

\subsection{RESULTS OF THE PV MODULE SURFACE TEMPERATURE VERIFIED BY DMM}

The measurements from the DHT11 sensor were verified using the Fluke 179 Digital Multimeter (DMM). The sensor measurement of $34^{\circ} \mathrm{C}$ in Figure 8 was judged against the DMM reading of $33.8^{\circ} \mathrm{C}$ and a percentage error calculated, using equation 3 arriving at an error percentage of $0.59 \%$, indicating that the measurements from the sensor are acceptable. 


\begin{tabular}{|c|c|c|c|c|c|c|c|c|c|c|c|c|}
\hline \multirow{3}{*}{$\frac{4}{1}$} & D & $\mathrm{F}$ & \multicolumn{2}{|r|}{ H } & 1 & J & K & L & M & \multicolumn{2}{|l|}{$\mathrm{N}$} & \\
\hline & Date & Time & - PVV & -1 & Bat V & Load V & - Batc & -1 & Load C & Temp & 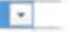 & \\
\hline & 27 Sep & $12: 55: 41$ & PM & 13.71 & 12.76 & 0.47 & 1.54 & 1.25 & -0.17 & & 41 & \\
\hline 420 & $27 \mathrm{Sep}$ & $12: 57: 21$ & PM & 13.69 & 12.76 & 0.47 & 1.54 & 1.25 & -0.17 & & 41 & \\
\hline 421 & $27 \mathrm{sep}$ & 01:00:42 & & 13.69 & 12.76 & 3.85 & 1.44 & 1.2 & -0.12 & & 38 & \\
\hline 422 & $27 \mathrm{Sep}$ & 01:02:23 & & 13.69 & 12.71 & 3.8 & 1.44 & 1.2 & -0.12 & & 38 & \\
\hline 423 & $27 \mathrm{Sep}$ & 01:04:03 & & 13.66 & 12.76 & 3.66 & 1.44 & 1.25 & -0.12 & & 37 & \\
\hline 424 & $27 \mathrm{Sep}$ & $01: 05: 44$ & PM & 13.69 & 12.76 & 3.41 & 1.44 & 1.25 & -0.12 & & 37 & \\
\hline 425 & 27 Sep & 01:07:24 & PM & 13.69 & 12.74 & 3.1 & 1.44 & 1.25 & -0.17 & & 37 & \\
\hline 426 & 27 Sep & 01:09:05 & PM & 13.71 & 12.76 & 2.63 & 1.44 & 1.2 & -0.12 & & 35 & \\
\hline 427 & 27 Sep & 01:10:46 & PM & 13.71 & 12.76 & 3.32 & 1.44 & 1.2 & -0.17 & & 34 & PV Surface Temperature \\
\hline 428 & 27 Sep & 01:12:26 & PM & 13.69 & 12.74 & 3.57 & 1.39 & 1.2 & -0.17 & & 34 & arifiad hanan \\
\hline 429 & $27 \mathrm{Sep}$ & 01:14:07 & PM & 13.57 & 12.68 & 3.49 & 1.3 & 1.05 & -0.17 & & 34 & verified by DMM \\
\hline 430 & 27 Sep & 01:17:28 & PM & 13.35 & 12.6 & 2.93 & 1.15 & 0.9 & -0.12 & & 33 & $\left(228^{\circ} \mathrm{C}\right)$ \\
\hline 431 & 27 Sep & 01:19:08 & PM & 13.29 & 12.57 & 2.51 & 1.05 & 0.81 & -0.12 & & 34 & $\left(33.8^{\circ} \mathrm{C}\right)$ \\
\hline 432 & 27 Sep & $01: 20: 49$ & PM & 13.29 & 12.57 & 2.51 & 1.05 & 0.81 & -0.12 & & 34 & \\
\hline 433 & $27 \mathrm{Sep}$ & 01:22:29 & PM & 13.27 & 12.51 & 1.98 & 1 & 0.76 & -0.12 & & 33 & \\
\hline 434 & $27 \mathrm{Sep}$ & $01: 24: 10$ & PM & 13.24 & 12.54 & 2.4 & 0.95 & 0.81 & -0.12 & & 32 & \\
\hline 435 & 27 Sep & $01: 25: 50$ & & 13.24 & 12.51 & 3.66 & 0.95 & 0.81 & -0.12 & & 32 & \\
\hline 436 & 27 Sep & 01:27:31 & PM & 13.24 & 12.51 & 3.77 & 0.95 & 0.81 & -0.17 & & 32 & \\
\hline 437 & $27 \mathrm{sep}$ & 01:29:11 & PM & 13.24 & 12.51 & 3.04 & 0.9 & 0.76 & -0.07 & & 32 & \\
\hline 438 & $27 \mathrm{Sep}$ & $01: 30: 52$ & PM & 13.24 & 12.51 & 3.04 & 0.9 & 0.76 & -0.07 & & 32 & \\
\hline 439 & $27 \mathrm{Sep}$ & $01: 32: 32$ & PM & 13.18 & 12.51 & 2.18 & 1 & 0.81 & -0.07 & & 32 & \\
\hline 440 & 27 Sep & $01: 34: 13$ & PM & 13.21 & 12.54 & 3.07 & 0.95 & 0.76 & -0.17 & & 32 & \\
\hline 441 & $27 \mathrm{Sep}$ & $01: 35: 53$ & PM & 13.24 & 12.51 & 3.66 & 0.95 & 0.76 & -0.12 & & 32 & \\
\hline 442 & $27 \mathrm{Sep}$ & 01:39:14 & PM & 13.21 & 12.51 & 3.66 & 0.95 & 0.76 & -0.12 & & 32 & \\
\hline 443 & 27 Sep & $01: 40: 55$ & PM & 13.21 & 12.51 & 3.32 & 0.95 & 0.76 & -0.12 & & 32 & \\
\hline 444 & $27 \mathrm{Sep}$ & $01: 45: 56$ & & 13.18 & 12.51 & 3.8 & 0.95 & 0.76 & -0.12 & & 32 & \\
\hline 445 & $27 \mathrm{Sep}$ & $01: 47: 37$ & & 13.21 & 12.51 & 2.09 & 0.95 & 0.76 & -0.12 & & 32 & \\
\hline 446 & 27 Sep & $01: 50: 58$ & PM & 13.18 & 12.51 & 0.34 & 0.9 & 0.61 & -0.07 & & 31 & \\
\hline , & +,$\ldots$ & 24Sept g & raphs & 25 Sept & $26 \mathrm{Sept}$ & 27 Sept & 27Sept graphs & 28 Sept & $29 \mathrm{Sept}$ & Sheet1 & $305 e$ & \\
\hline
\end{tabular}

Figure 10. PV module surface temperature measurements verified by DMM.

Source: own elaboration.

\subsection{RESULTS OF THE PRACTICAL SETUP MEASUREMENT OF PV SURFACE TEMPERATURE OVER 29 DAYS}

Figure 11 reflects hourly maximum PV surface temperature measurements for a cloudy day. The maximum surface temperature for 29 September 2019 is recorded as $39^{\circ} \mathrm{C}$ at 09:00 am. Figure 12 reflects hourly maximum PV surface temperature measurements for a sunny day. The maximum surface temperature for 27 September 2019 is recorded as $54^{\circ} \mathrm{C}$ at 12:00 pm. 


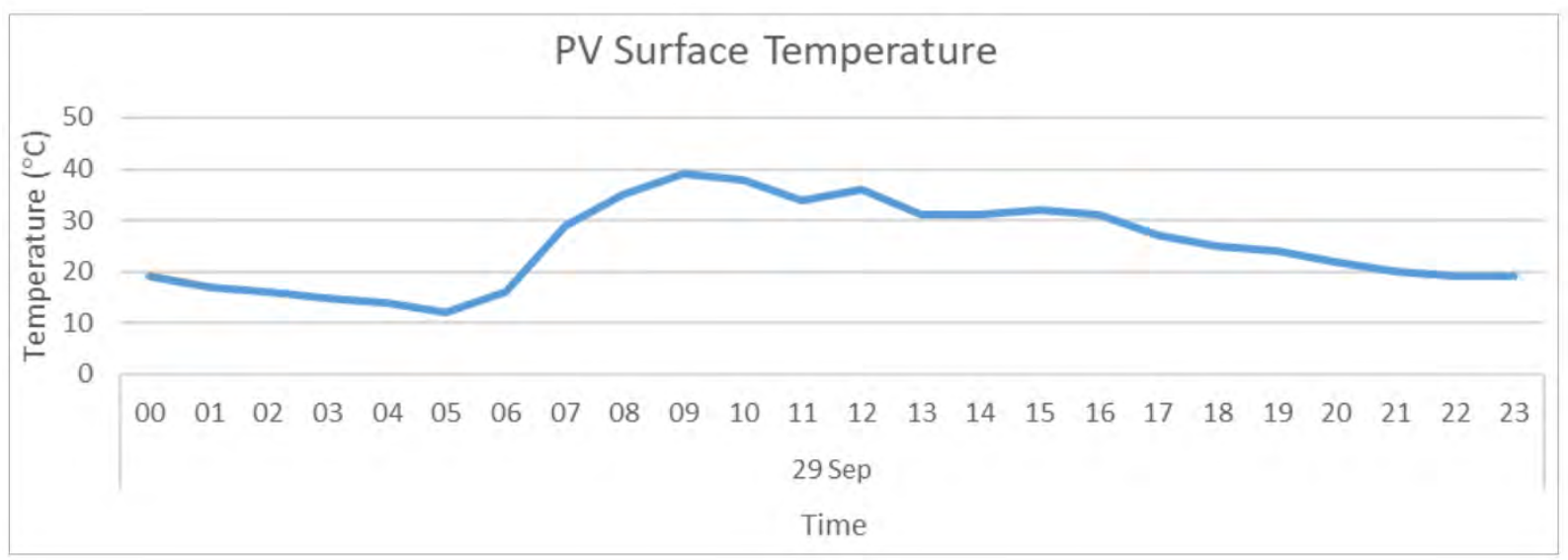

Figure 11. Hourly maximum of PV module surface temperature for 29 September 2019 (Cloudy day).

Source: own elaboration.

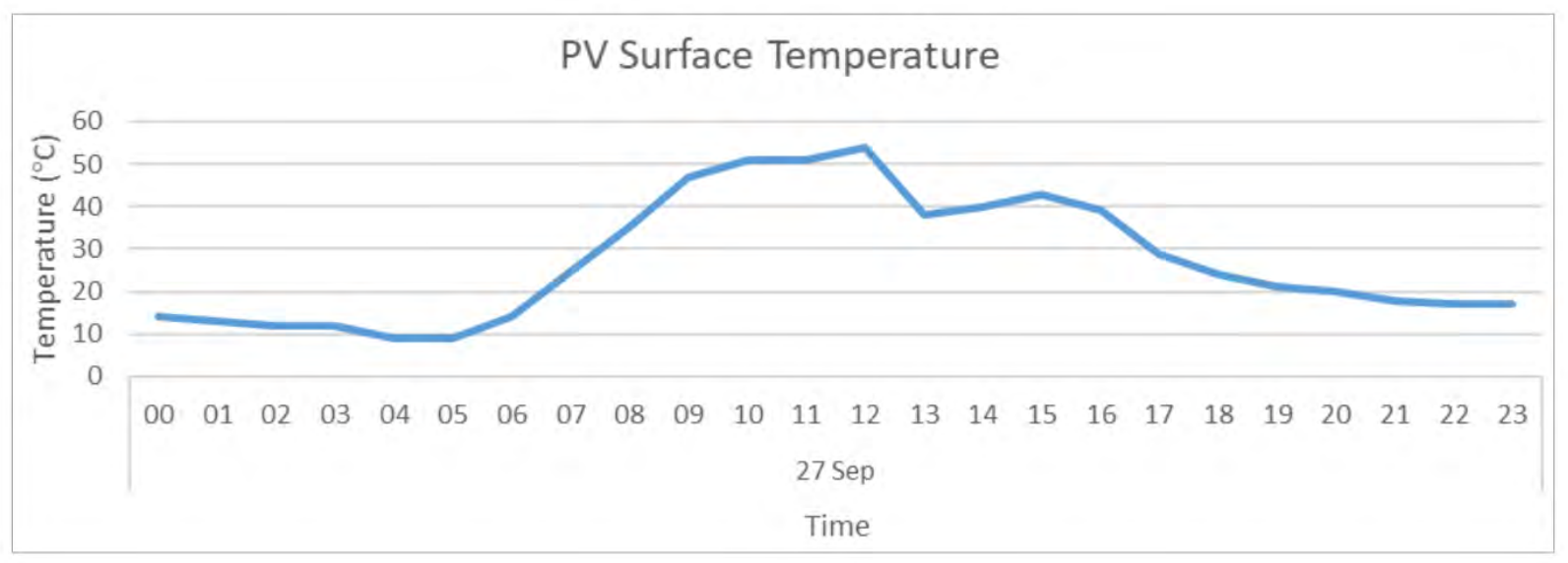

Figure 12. Hourly maximum of PV module surface temperature for 27 September 2019 (Sunny day).

Source: own elaboration. 
PV surface temperature $\left(T_{P V}\right)$ data from the DHT11 sensor is presented in Figure 13, together with the ambient temperature $\left(T_{a}\right)$ data for Bloemfontein in South Africa, obtained from timeanddate.com (Time and Date, 2020). The $T_{a}$ data available from the website is given in maximum and minimum for 00:00, 06:00, 12:00 and 18:00 for any required day. The available maximum and minimum $T_{a}$ was then captured and processed, using pivot tables where daily maximum and minimum $T_{a}$ were obtained. The $T_{P V}$ data was sampled every 100 seconds from 19 July to 16 August 2019, where the highest surface temperature was recorded to be $55^{\circ} \mathrm{C}$ on 14 August. Pivot tables were used - due to the sheer quantity of data that had to be analysed - to determine the hourly maximum and minimum $T_{P V}$ values per day, and from those a daily maximum and minimum $T_{P V}$ was derived. Results indicate that the surface temperature follows the same profile as the ambient temperature, suggesting reliability of the measurements.

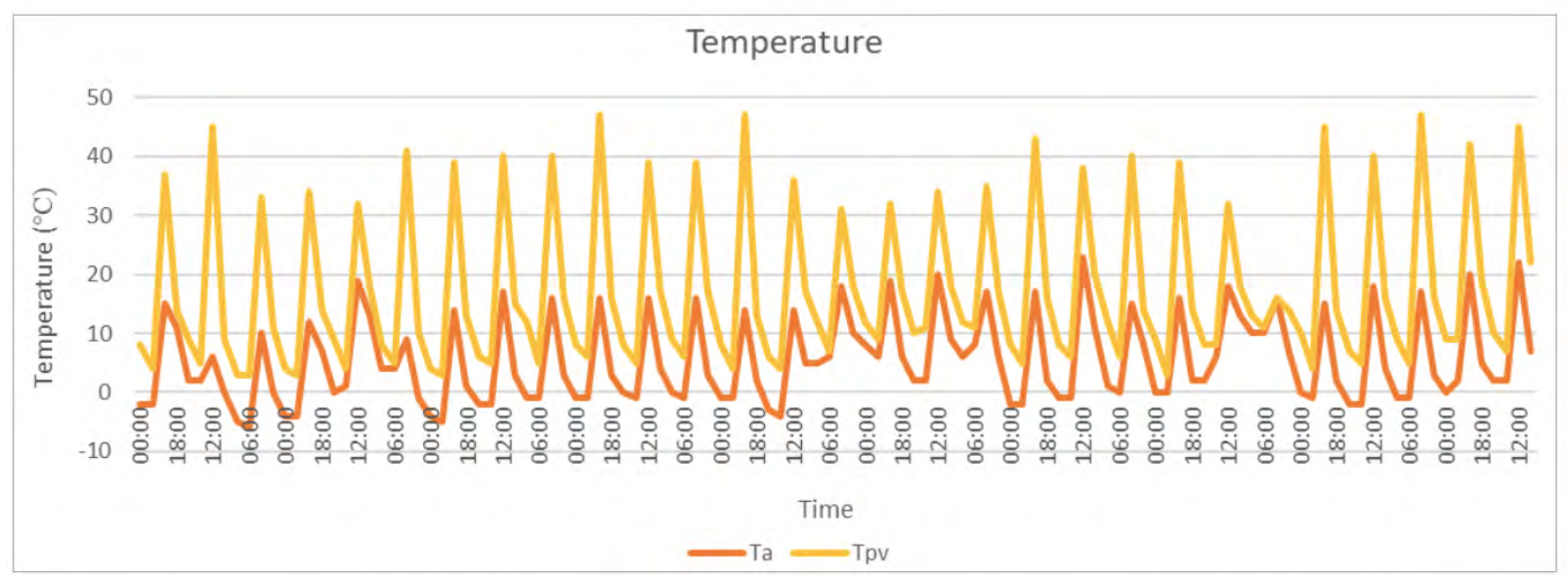

Figure 13. Ambient and PV surface temperature.

Source: own elaboration. 


\section{CONCLUSIONS}

Sensor measurements (voltage, current and temperature) were obtained from the remote ST and sent to the MT using the CG1 101 transceiver. The daily maximum of the voltage was recorded to be between 12.76 $\mathrm{V}$ and 15.44 for the said period, thereby not exceeding the rated $V_{m p}$ of $16.5 \mathrm{~V}$ for these PV modules. In addition, the PV current that was measured remotely for the same period, indicated more current for a sunny day $(2.32 \mathrm{~A})$ than a cloudy day $(1.98 \mathrm{~A})$, both which are less than the rated $I_{m p}$ of 2.44 A. These results showed a $4.9 \%$ error percentage for voltage measurements and a $3.9 \%$ error percentage for current measurements.

Temperature measurements were also taken remotely arriving at an error percentage of $0.59 \%, T_{P V}$ was observed to be significantly higher than $T_{a}$ during the day and more so around midday. An even wider gap was seen in the two parameters on a sunny day, compared to a cloudy day, whereas at night, $T_{P V}$ and $T_{a}$ were evidently similar.

The research did not focus on the different types of PV modules, actuators or solenoid valves. The inclusion of an energy regulator and storage system also did not form part of the research. This research has unfolded possibilities of future studies that could contribute to the work of maintaining optimum power of PV modules. This includes comparing the effect of cooling the PV module using a water sprayer in relation to a change in the orientation angle on the output power of the module. Incorporating cloud storage for monitoring of the output power and surface temperature from any location at any time can also be considered for further research.

\section{REFERENCES}

Allegro Microsystems. (2006). Fully Integrated, Hall Effect-Based Linear Current Sensor with 2.1 kVRMS Voltage Isolation and a Low-Resistance Current Conductor. 
Andrae, A.S., \& Edler, T. (2015). On global electricity usage of communication technology: trends to 2030. Challenges, 6(1), 117-157. https://doi.org/10.3390/challe6010117

Arduino. (2018). Arduino Mega 2560 Rev3. https://store.arduino.cc/arduino-mega-2560-rev3

Atsu, D., Seres, I., Aghaei, M., \& Farkas, I. (2020). Analysis of long-term performance and reliability of PV modules under tropical climatic conditions in sub-Saharan. Renewable Energy, 162, 285-295. https://doi.org/10.1016/j.renene.2020.08.021

Bai, A., Popp, J., Balogh, P., Gabnai, Z., Pályi, B., Farkas, I., Pintér, G., \& Zsiborács, H. (2016). Technical and economic effects of cooling of monocrystalline photovoltaic modules under Hungarian conditions. Renewable and Sustainable Energy Reviews, 60, 1086-1099. https://doi. org/10.1016/j.rser.2016.02.003

Belmili, H., Gheikh, S. M. A., Haddadi, M., \& Larbes, C. (2010). Design and development of a data acquisition system for photovoltaic modules characterization. Renewable Energy, 35(7), 14841492. https://doi.org/10.1016/j.renene.2010.01.007

Bhattacharya, T., Chakraborty, A.K., \& Pal, K. (2014). Effects of ambient temperature and wind speed on performance of monocrystalline solar photovoltaic module in Tripura, India. Fournal of Solar Energy, 2014, Article ID 817078. https://doi.org/10.1155/2014/817078

D-Robotics. (2010). DHT11 Humidity \& Temperature Sensor. https://www.circuitbasics.com/wp-content/ uploads/2015/11/DHT11-Datasheet.pdf

El Hammoumi, A., Motahhir, S., Chalh, A., El Ghzizal, A., \& Derouich, A. (2018). Low-cost virtual instrumentation of PV panel characteristics using Excel and Arduino in comparison with traditional instrumentation. Renewables: wind, water, and solar, 5(3), 1-16. https://doi.org/10.1186/ s40807-018-0049-0 
Ertekin, G., \& Yaldiz, O., (2000). Comparison of some existing models for estimating global solar radiation for Antalya (Turkey). Energy Conversion and Management, 41(4), 311-330. https://doi. org/10.1016/S0196-8904(99)00127-2

Fuentes, M., Vivar, M., Burgos, J. M., Aguilera, J., \& Vacas, J. A. (2014). Design of an accurate, low-cost autonomous data logger for PV system monitoring using Arduino that complies wih OEG standards. Solar Energy Materials \& Solar Cells, (130), 529. https:// librarysearch.rgu.ac.uk/discovery/fulldisplay?docid=cdi_gale_infotracacademiconefile_ A522384896\&context=PG\&vid=44RGU_INST:VU1\&lang=en\&search_scope=MyInst_and_ CI\&adaptor $=$ Primo $\% 20$ Central\&tab $=$ Everything\&query $=$ sub,exact, $\% 20 I$ EC $\% 20$ standards

Gay, W. (2018). DHT11 Sensor. Advanced Raspberry Pi. Springer, pp. 399-418.

Kama, A., Diallo, M., Drame, M.S., Ndiaye, M.L., Ndiaye, A., \& Ndiaye, P.A. (2017). Monitoring the performance of solar street lights in sahelian environment: Case study of Senegal. In 2017 10th International Conference on Developments in eSystems Engineering (DeSE), IEEE, pp. 56-61.

Kekre, A., \& Gawre, S.K. (2017). Solar photovoltaic remote monitoring system using IOT. In 2017 International Conference on Recent Innovations in Signal processing and Embedded Systems (RISE), 2017, pp. 619-623. https://doi.org/10.1109/RISE.2017.8378227

Koutitas, G., \& Demestichas, P. (2010). A review of energy efficiency in telecommunication networks. Telfor journal, 2(1), 2-7. https://journal.telfor.rs/Published/Vol2No1/Vol2No1_A1.pdf

Liu, J., Fang, W., Zhang, X., \& Yang, G. (2015). An improved photovoltaic power forecasting model with the assistance of aerosol index data. IEEE Transactions on Sustainable Energy, 6(2), 434-442. https:/ /ieeexplore.ieee.org/document/7029108

Nedelchev, I., \& Zhivomirov, H. (2020). A combined approach for assessment the functionality of photovoltaic modules in real-world operation. In E3S Web of Conferences 2020, EDP Sciences, pp. 02006. https://doi.org/10.1051/e3sconf/202018002006 
Ortega, E., Aranguren, G., Saenz, M. J., Gutierrez, R., \& Jimeno, J. G. (2018). Photovoltaic Module to Module Monitoring System. In 2018 IEEE 7th World Conference on Photovoltaic Energy Conversion (WCPEC) (A Joint Conference of 45th IEEE PVSG, 28th PVSEG \& 34th EU PVSEC) 2018, pp. 2703-2708.

Peng, Z., Herfatmanesh, M.R., \& Liu, Y. (2017). Cooled solar PV panels for output energy efficiency optimisation. Energy conversion and management, 150, 949-955. https://core.ac.uk/download/ pdf/161941461.pdf

Prieto, M.J., Pernía, A.M., Nuño, F., Díaz, J., \& Villegas, P.J. (2014). Development of a wireless sensor network for individual monitoring of panels in a photovoltaic plant. Sensors (Basel, Switzerland), 14(2), 2379-2396. https://doi.org/10.3390/s140202379

Randhir, M., \& Karhe, R.R. (2015). Monitoring Of Environmental Parameters by Using Cloud Computing. International Fournal of Computer Science Trends and Technology (IFCST), 3(3), 151-155. http:/ / www.ijcstjournal.org/volume-3/issue-3/IJCST-V3I3P27.pdf

Rasberry Pi. (2018). Rasberry Pi 3 model b+. https://www.raspberrypi.org/products/raspberry-pi-3model-b-plus /

Schwingsshack1, G., Petitta, M., Wagner,J.E., Belluardo, G., Moser, D., Castelli, M., Zebisch, M., \& Tetzlaff, A. (2013). Wind effect on PV module temperature: Analysis of different techniques for an accurate estimation. Energy Procedia, 40, 77-86. https://doi.org/10.1016/j. egypro.2013.08.010

Spagnuolo, A., Petraglia, A., Vetromile, C., Formosi, R., \& Lubritto, G. (2015). Monitoring and optimization of energy consumption of base transceiver stations. Energy, 81, 286-293. https:// ideas.repec.org/a/eee/energy/v81y2015icp286-293.html 
Swapnil, D., Jatin, S., \& Bharath, S. (2013). Temperature Dependent Photovoltaic (PV) Efficiency and Its Effect on PV Production in the World - A Review. Energy Procedia, 33, 311-321. https:// doi.org/10.1016/j.egypro.2013.05.072

Telkom, S.A. (2018). 2018 Telkom sa integrated report. http://telkom-reports.co.za/reports/ar-2018/pdf/ full-integrated.pdf

Texas Instruments. (2018). CC1101 Low-Power Sub-1 GHz RF Transceiver. http://www.ti.com/lit/ds/ symlink/cc1101.pdf

Time and Date. (2020). 2020-last update. Fuly 2019 Weather in Bloemfontein - Graph. https://www. timeanddate.com/weather/south-africa/bloemfontein/historic? $\mathrm{month}=7$ \&year=2019

Tina, G.M., \& Grasso, A.D. (2014). Remote monitoring system for stand-alone photovoltaic power plants: The case study of a PV-powered outdoor refrigerator. Energy Conversion and Management, 78, 862-871. https://doi.org/10.1016/j.enconman.2013.08.065 


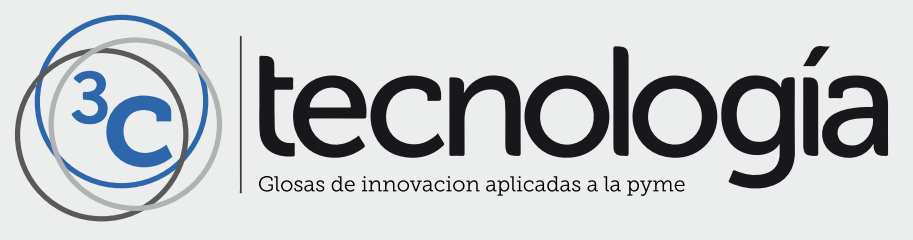

